GEOLOGICAL FORMATIONS

of

IOWA.

BY

CHARLES ROLLIN KEYES. 



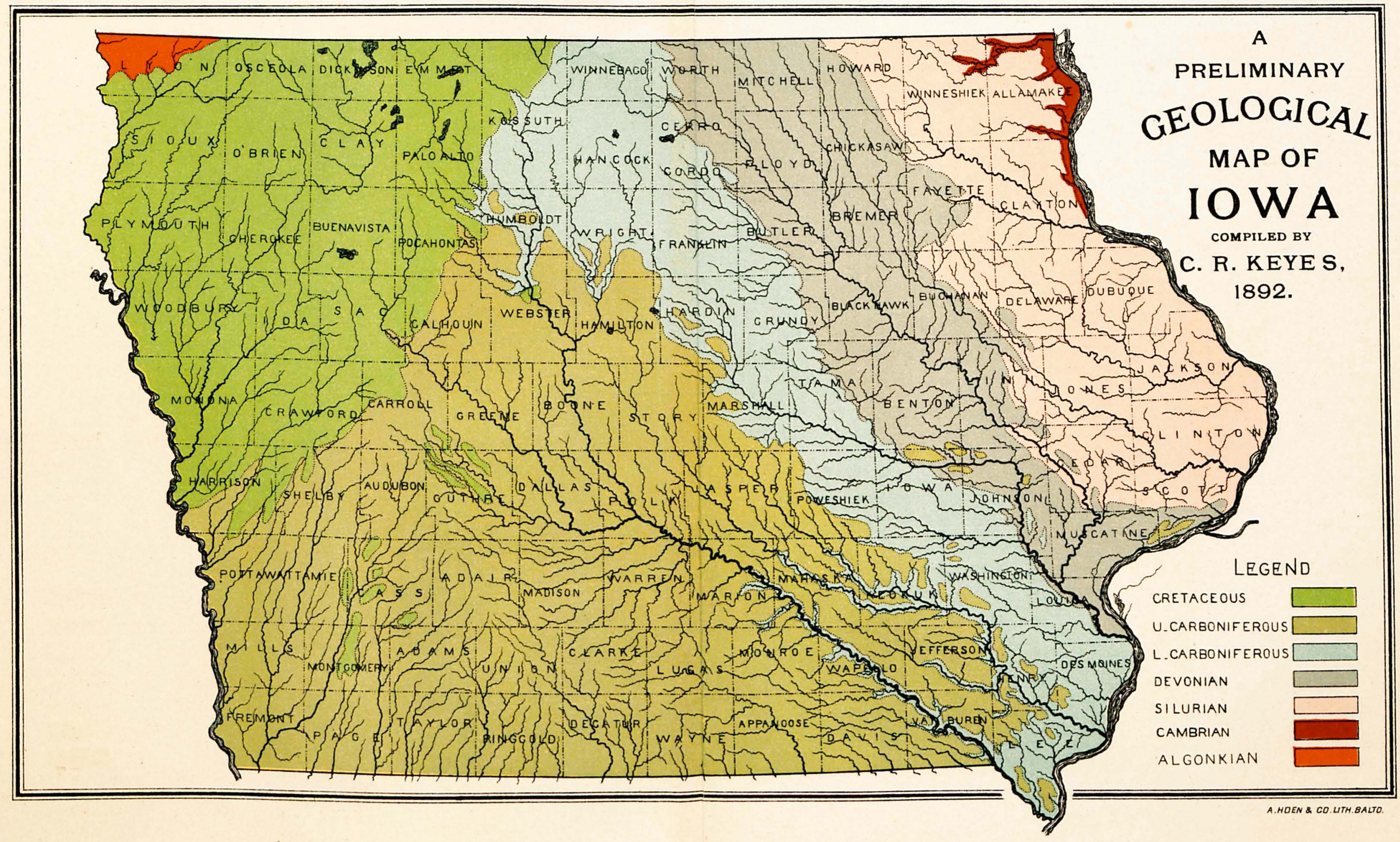





\section{THE GEOLOGICAL FORMATIONS OF IOWA.}

BY CHARLES ROLLIN KEYES.

\section{INTRODUCTORY.}

Geology is pre-eminently an economic science. It comprehends all the facts known in regard to the rocks and mineral contents of the earth. It considers all the uses to which these substances are applied. It points out the capacities of all natural resources and indicates the best means of developing the mineral wealth of a region.

At no time in the history of Iowa has the economical value of her rocky deposits been fully appreciated. Other interests have so overshadowed the industries connected with the development of the natural resources that it is almost forgotten that our material domain is one of the richest in the world. Nature has done much; we have done but little.

Few Iowans are not too busily engaged with their own affairs to ponder for a little while that they may see how important a part the mineral resources have played in the material advancement of the State; how great will be the advantage of closer attention to this subject. Laborer, merchant, artisan, agrieulturist, manufacturer, and capitalist, all are affected by a knowledge of the natural products of the community.

By their contained fossils the stratified rocks of the globe are knowh. In arranging the strata according to 
their geological ages the geologist is able to predict what mineral deposits are likely to be found in given beds; what are not to be expected; and what ones are surely not present in quantities of economic value.

At the outset, then, it is desirable to know which of the geological formations are represented within the limits of the State, and which are not; also to have some standard of comparison with the strata of other regions. The accompanying chart shows the general geological section of the rocks as represented in Iowa. (Plate ii.) It will be seen at a glance that the geological formations of the State are measurably complete. The distribution of each is shown on the map of the State given on plate $i$.

Everywhere over Iowa spreads a thick mantle of drift, the debris left by the retreat of the great ice sheets of two different periods. The glacial deposits have such a great thickness in many parts of the State that the older rocks are completely hidden from view over large areas. Much difficulty is thus encountered in attempting to decipher the geological features of these regions. Over most of the State, however, the streams, in cutting down their channels, have passed entirely through the drift materials, and have exposed numerous sections of the indurated rocks.

The accompanying sketch of the geological formations of Iowa is based chiefly upon personal notes made by Professor Calvin, who has given particular attention to the older rocks-Cambrian, Silurian and Devonian; and upon the observations of the writer, who has been brought in contact more especially with the Devonian, lower Carboniferous and Coal Measures of the State. Numerous references have also been made to the information published by White, and especially by MeGee. 
IOWA GEOLOGICAL SURVEY.

PLATE 2

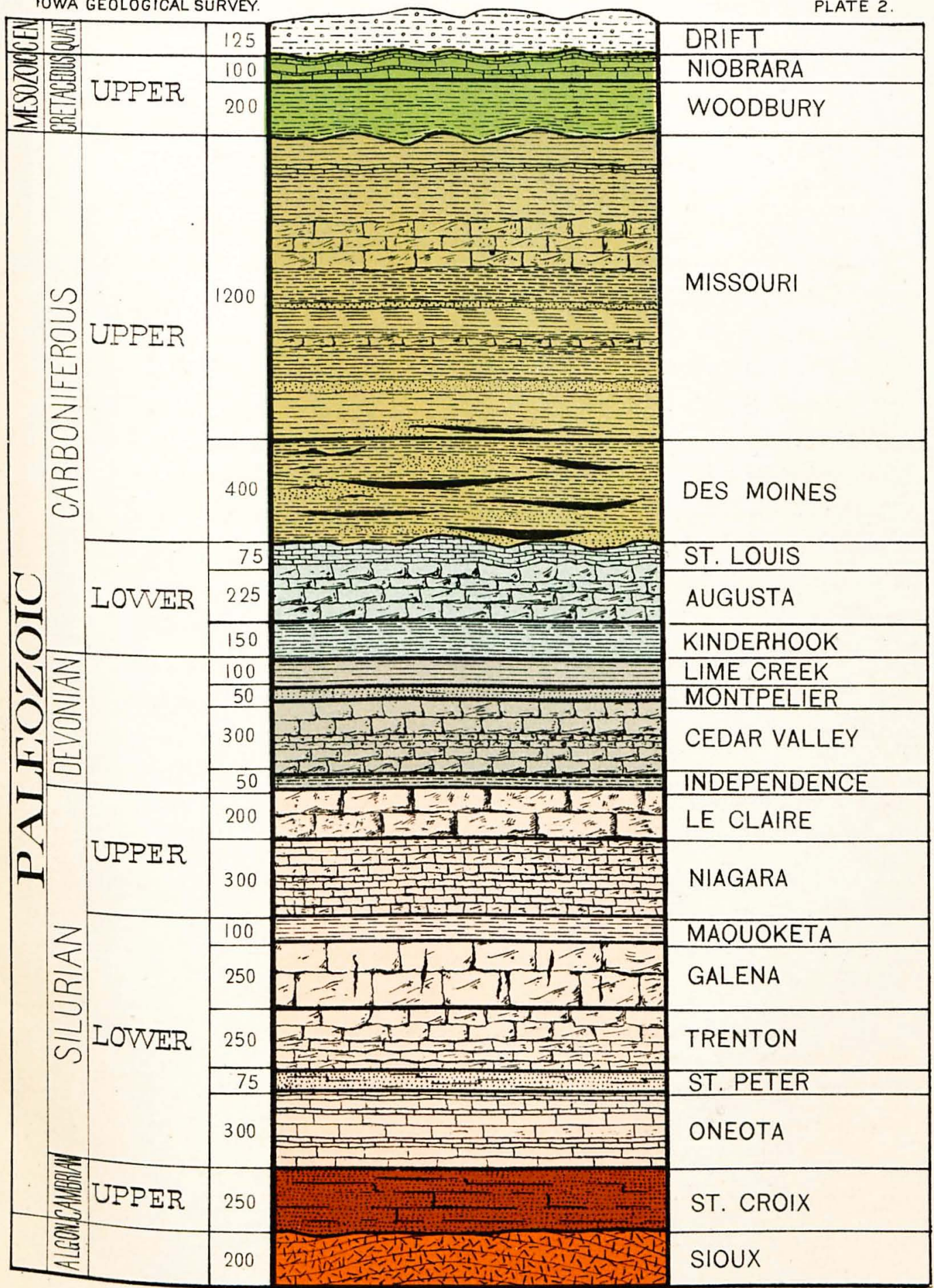

GENERAL GEOLOGICAL SECTION OF IOWA. 



\section{CRYSTALLINE ROCKS.}

The stratified rocks of Iowa doubtless rest at no very great depth upon the erystalline basement which is supposed to underlie all the sedimentary rocks of the globe. The upper zone of this great fundamental complex, composed of granites, gneisses, gabbros, and other igneous masses, is well exposed north of the State, in central Minnesota and in Wisconsin. South of Iowa the nearest surface exposure is in the Iron Mountain district of southeastern Missouri.

. The only metamorphosed or massive crystalline rocks having a surface exposure within the limits of Iowa are found in the extreme northwestern corner of the State. The formation has long been known as the Sioux Quartzite. According to Irving it ranges lithologically from a "loose sandstone to the hardest and most completely vitreous quartzite, the prevalent phase being a distinctly quartzitic one. The loosest and most completely indurated portions are arranged in the most irregular relations to one another. Occasionally they will be interstratified. At times the exposed portions will be completely vitrified, while below artificial openings will display an entirely loose sandstone, suggesting an induration of the exposed portions by weathering. In other cases, however, exactly the reverse of this will be met with, while very often the more and less indurated phases pass into each other laterally by rapid gradations, the two phases traversing the layers and dovetailing into each other in the most irregular manner. The prevalent color of the formation is red, but the loosest varieties are often very pale-colored,- while the most vitreous kinds frequently present à very dark purple hue. In western Minnesota, and again in certain points of Dakota, there is associated with the quartzite the 
fine clayey rocks known as pipestone or catlinite. Intermediate between this pipestone and the purely silicious quartzite are clayey sandstones and quartzites, often of a blotched appearance, and not a little resembling externally certain of the Keweenawan sandstones of Lake Superior. So far as microscopic studies have gone these. rocks are in the main mixtures of red clay and quartz. Conglomeratic phases of the quartzite are met with at a number of points, but no other rocks but those already mentioned have been recognized in this great formation."

It has been generally reported that no other crystalline rocks appear in the neighborhood of the Sioux Quartzite outcrop. It is of considerable interest, then, to know that G. E. Culver* has very lately discovered in the midst of the quartzite of southeastern Dakota, in Minnehaha county, within a few miles of the Iowa boundary, or more accurately, in sections 15 and 22, range xlix. west, township 101 north, a large mass of diabase exposed for fully a mile along one of the tributaries of the Big Sioux.

Hobbs, $\uparrow$ who has examined the intrusive rock mieroscopically, finds it to be a well pronounced coarse-grained olivine diabase, with hornblende, biotite, ilmenite, and apatite present in addition to the plagioclase, augite, and olivine.

The presence of this massive basic rock of undoubted eruptive origin is very suggestive of the agencies that may have been involved to some extent in metamorphosing the old Sioux sandstone. Further investigation will doubtless disclose other similar types of eruptives in the quartz-

\footnotetext{
* Culver and Hobbs: On a New Occurrence of Olivine Diabase in Minnehaha County, South Dakota. (Trans. Wisconsin Acad. Sci., Arts and Letters, Vol. VIII., pp. 206-210. Madison, 1892.)

†Loc. cit.
} 
ites of the neighborhood in all three of the States already mentioned.

The quartzite still has its planes of sedimentation clearly defined. It lies in low folds which are quite marked in places.

Concerning the geological age of the Sioux Quartzite a number of different opinions have been expressed.

From the first mention of this formation by Catlin in 1837 in connection with the celebrated pipestone quarry until 1866, when Hall entered the region, no suggestion was made regarding the age of the flint-like mass. Nicollet visited the quarry in 1838 and gave a very complete description of the rock, but for nearly thirty years no special notice appears to have been taken of the place. Hall, though not seeing all the exposures, concluded that the quartzite beds must be Huronian in age. Hayden, who examined the rocks about the same time, thought he had ample reasons for regarding them as Triassic or Cretaceous. In connection with his work in Iowa, White was led to adopt Hall's opinion ; while Winchell, approaching the region from the Minnesota side, referred the hardened sand-bed to the Potsdam-upper Cambrian. Still later Irving expressed his view to the effect that the Sioux Quartzite was Huronian.

Though very little information bearing directly upon the geological age of the indurated sandstones of the Big Sioux region is yet available, certain recent observations on the geology of northwestern Iowa are not without interest.

During the past few years a number of deep wells or borings have been made in different parts of the State. The depths reached are from 1,200 or 2,000 feet. Several 
of these deep borings are of particular interest, as they pass through all of the sedimentary rocks into the erystalline basement below, penetrating the latter in somecases to the extent of several hundred feet. A typical. gray granite has been recognized in some instances; in others, different types of eruptive rock.

The latest boring in the northwestern part of the State is the well at Hull, in Sioux county. At a very considerable depth several thick beds of flint-like rock were passed. through. The different beds of the rock were separated by gravels to the thickness of several feet, if the samples and records are to be relied upon. Some of the flint-likefragments were sliced, and upon petrographical examination proved to be typical quartz-porphyry-a truly igneous rock, very acid in character, and essentially identical with granite, but cooling under somewhat different physical conditions. Under the microscope the ground-mass appears microgranitic, with large clear crystals of quartz and feldspar scattered through it.

Now the presence of these undoubted eruptive rocks in situ at no very great distance below the surface of the ground in the northwestern part of the State, the existence of diabasic masses in the midst of the quartzite mass itself, the folded and disturbed condition of the strata, all point to the great antiquity of the Sioux formation, as compared with other rocks exposed within the limits of Iowa. The inference is, then, that the rocks under consideration must be very much older than any others known within the boundaries of the State.

It has been lately found that the exposures of Sioux Quartzite in southeastern Dakota are much more numerous than was formerly supposed, and that the hardened sandstone has a much wider geographical distribution than 
has heretofore been assigned to it. In Iowa its outerop is known twenty-five to thirty miles farther eastward than has been reported heretofore. There are large exposures in Lyon county, in the vicinity of Rock Rapids, where it is quarried. Borings indicate a much farther eastern occurrence of these rocks. The Cretaceous covering appears to be relatively thin to the northwestward, so that the quartzite outcrops of the Sioux Falls vicinity may really be regarded as a part of the southwestern extension of the great Minnesota complex of crystaliine rocks.

No remains of fossils have ever been found in the Sioux formation giving any indication of its geological age.

Uses.-Although quarried with considerable difficulty in places, much of the quartzite is jointed and cracked in such a manner as to make it possible to get it out readily in convenient sizes for handling. Being one of the most compact and most durable of building stones, it is rapidly becoming popular for architectural purposes throughout the region. Churches and other buildings at Des Moines, Burlington, Council Bluffs, Sioux City, and Omaha, Nebraska, have been constructed of this rock with very pleasing effects. It has also been used with great success as a paving material, both in blocks and as macadam. The chief quarries in Iowa are near Rock Rapids, in Lyon county, though the development of the quarry industry here is not so great as at Sioux Falls, South Dakota. The opportunities and facilities for obtaining practically inexhaustible quantities of the Sioux Quartzite, or "Sioux -Granite," as it is perhaps more commonly called, are fully equal to those of the Dakota localities. 


\section{CAMBRIAN.}

SAINT CROIX SANDSTONE.

This is the "Potsdam" sandstone of most writers on the geology of the Upper Mississippi valley. The name here used was given by Winchell to those rocks of southeastern Minnesota and the adjoining portions of the neighboring states regarded by Owen, Hall, White and others as the western extension of the Potsdam of New York.

The strata of this stage are well exposed in the northeastern corner of the State, in the bottom of the gorges of the Mississippi river and its tributaries. It is everywhere in the region capped by limestone beds much more durable than the sandrock. The greatest exposed thickness of this formation in the State is somewhat over 250 feet. Borings for artesian wells show the entire thickness to be not less than 1,000 feet.

Lithologically the Saint Croix, as represented in this State, is largely an unconsolidated sand-bed, disintegrating rapidly under the influence of weather and erosion. Thin argillaceous and calcareous seams are frequently. developed. In the adjacent states these seams assume more importance and form clayey shales and shaley limestone layers, which often contain remains of trilobites.

At Lansing certain thin beds of this formation are sufficiently indurated to furnish an inferior quality of building stone, which is quarried locally for rough masonry. In many places the sandstone is quite incoherent and is capable of furnishing large quantities of coarse and fine building sand. Beyond the boundaries of the State the light colored layers are used for the manufacture of glass.

Although manifestly a distinct formation from the 
Potsdam sandstone of the Appalachian region, the Saint Croix contains the fauna of the Dikelocephalus zone, or upper Cambrian, and therefore may be regarded paleontologically equivalent to the Potsdam of New York.

No attempt has yet been made in Iowa to subdivide the formation into minor groups of beds. In Wisconsin, where the Saint Croix rocks assume much greater importance than elsewhere, a number of subdivisions have been made out. The same is true of Alinnesota, where the rocks of this age are also much better developed than in Iowa.

\section{SILURIAN.}

ONEOTA LIMESTONE.

This has commonly been known as the Lower Magnesian limestone. Though exposed over only a small area in the northeastern corner of the State, it forms quite an important quarry rock. It caps the bluffs of the Mississippi and its tributaries, rising in tall mural escarpments above the soft Saint Croix sandstone. The precipitous cliffs and castellated walls rise picturesquely above the heavy talus at the base of the canyons. Lithologically it is an impure dolomite, with occasional thin sandstone seams in the upper part. The rock is "coarsely saccharoidal, frequently vesicular and cavernous, and generally buff, yellow or light brown in color. To the tourist upon the Mississippi it is the most conspicuous among the formations of the bluffs; for like the Niagara, it well resists erosion and weathering, and is carved by corrasion into the precipitous salients and mural scarps overlooking the great river from Clayton northward. Its thickness ranges from over 300 feet at the Minnesota line to something more than 200 at its southernmost exposure; yet despite its prominence in the river bluffs and its considerable thick- 
ness, the terrane is narrow and the outcrops almost confined to the canyon walls of the Mississippi, the Oneota, the Yellow, and their minor tributaries.

The magnesian and arenaceous limestone to which the name is applied is the principal member of the vaguely defined series of beds which Owen in 1852 called the Lower Magnesian limestone. Owen's name was retained by Hall in 1858, and by White in 1870 ; but more recent studies, particularly in Minnesota and Wisconsin, have shown that the St. Peter, the Lower Magnesian of Owen, and the Potsdam, comprise a series of sandstones, shales and magne- sian limestones, representing continuous sedimentation from the later part of the Cambrian well into the Silurian, which are indeed often locally distinct, but which, nevertheless, are found to merge by interbedding, by gradual transition of sediments, and by intermingling of faunas when viewed in a large way. The Minnesota succession has been admirably worked out by $\mathrm{N}$. H. Winchell, * and that of Wisconsin has been equally well elucidated by Chamberlin and his collaborators. $f$ The formations recognized and the relations generally accepted by the geologists of both states are illustrated and both series correlated with the simpler Iowa series in the accompanying table :

${ }^{*}$ Geol. Nat. Hist. Surv. Minnesota, Final Rep., Vol. II., pp. 12-23. 1888.

tGeol. Wisconsin, Vol. I., pp. 119-144. 1883 . 
Siluro-Cambrian Formations of Wiscousiu, Minnesota, and Iowa.

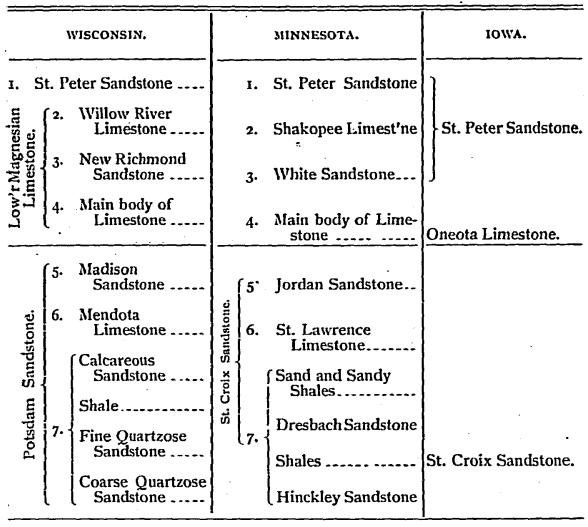

The correlation of the first six members appears definite and satisfactory, though none of the formations are uniform in composition and thickness throughout any considerable area in either state, nor were they probably synchronous in widely separated localities, save in a general way. The early Paleozoic continent rose and fell unequally. The early Paleozoic ocean shoaled and deepened alternately at each locality. Sandstones were formed there, and limestones everywhere, in ever-varying succession as the relation of land and water changed. In the lower part of the column, however, the conditions of deposition were still more inconstant, and the deposits recognized in the first two states respectively cannot be corre- 
lated, nor can they be identified certainly in the alternating beds of sandstone and shale forming the part of the Potsdam exposed in Iowa.

Formation No. 4 was designated the "main body of limestone" by Irving, " and the same term with like definition is used by N. H. Winchell. This mass of dolomite constitutes the principal part of the Lower Magnesian limestone of Owen, and is the sole remnant of his vaguely defined series for which the name might with any degree of propriety be retained. But the definition and taxonomic value of the part are obviously unlike those of the whole. Owen's series has been abandoned by modern systematists; the term itself is objectionable in that its correlative element has been meaningless since the division of the original Upper Magnesian limestone into three formations, and in that the lithological element is not strictly applicable, and so the name of the river upon which the rock-mass finds its typical development, not only for northeastern Iowa but for the country at large, may be applied to the formation." $\dagger$

This rock is quarried principally in Lansing, Waukon, McGregor, and elsewhere in Clayton and Allamakee counties. It is also used in making lime. Occasionally considerable amounts of lead ore are found in it, but as yet not in paying quantities.

SAINT PETER SANDSTONE.

Overlying the Oneota limestone is a heavy bed of pure silicious sandstone, very friable and with few lines of stratification. It is sometimes somewhat indurated, but as a rule very incoherent. This is the formation that has long been noted in the Upper Mississippi region under the

${ }^{*}$ Am. Jour. Sci., (3), Vol. IX, p. 442. IS75.

†McGee: U. S. Geol. Sur., IIth Ann. Rep., pp. 331-333. Washington, 1893. 
name of the "pictured" rocks, best exposed, perhaps, in the vicinity of McGregor. Along the boundary of the State northward thin limestone layers are often intercalated. the most important of which has been named the Shakopee limestone. In places this sand formation graduates downward by a rapid increase of calcareous matter into the Oneota limestone. Economically it is of considerable importance in Iowa, though furnishing no quarry rock of any kind. Many of the sand layers are very pure and form a high grade of material for the manufacture of glass. A number of glass factories at Milwaukee and elsewhere have for several years been supplied with sand from Iowa localities. Iron furnaces also use quantities of it.

A chemical analysis by Prof. G. E. Patrick of a sample of this glass sand from the pits of Mr. J. H. Buhlman, of Clayton, shows the following results:

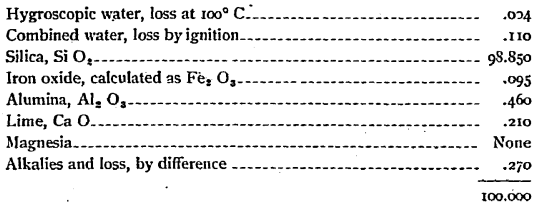

TRENTON LIMESTONE.

Contrasting sharply with the other Silurian limerocks of Iowa, the Trenton is an ordinary blue limestone instead of a dolomite. For the most part it is a very compact rock, though highly fossiliferous. Owing to its difference in lithological characters from the other Silurian limestones it is honeycombed in places by cavities and caverns of greater or less extent. "It constitutes a conspicuous feature of the Mississippi river bluffs from above McGregor 
to near Eagle point, Dubuque, and occurs as the surface rock over all or part of the counties of Allamakee, Howard, Winneshiek, Fayette, and Clayton. The Trenton limestone is interesting to the scientist on account of the number and beauty of the fossil remains inclosed in some of the strata. Here occur the oldest types of life that have been preserved in any degree of perfection within the limits of the State. The old Potsdam trilobites are few and fragmentary, and their structural characters are very obscure. In the Trenton are found countless multitudes of organic remains literally crowded together, and retaining in absolute perfection every structural feature, even to the minutest detail. Owing to the slight southerly or southwesterly dip, the strata pass successively below the level of the Mississippi river, and so just above Dubuque the Trenton limestone disappears from view."* It is quarried in numerous places throughout the counties mentioned, the fine-grained layers producing building stone of great durability. Lime of very good quality is made from this stone. Certain of the clay shales afford good material for the manufacture of light colored brick.

GALENA LIMESTONE.

Overlying the Trenton limestone in northeastern Iowa is a heavily bedded brown dolomite which attains a maximum thickness of between two and three hundred feet in the vicinity of Dubuque. In many places it is very coarse, vesicular and unevenly textured, and frequently contains some cherty matter. The entire bluffs at Dubuque are formed of this limestone. Some sandy material is present in different portions of the formation. The part-

${ }^{*}$ Calvin: Iowa: Notes on the Geological Formations, pamphlet, p. 5. I883. 
ings are usually argillaceous and are more massive and important toward the top where the formation gradually passes into the overlying shales, as shown by Chamberlin. The conditions of the deposition arrived at in southwestern Visconsin and vicinity were changed somewhat from

- those that had existed during the Trenton. This change was quite important. "As the strata now lie they form a low arch having a north and south axis extending through the center of the State, broad at the north, but narrowing and dying away at the south. The strata on the eastern side slope toward Michigan, which occupies a broad stratigraphical depression; on the west toward Minnesota and Iowa, which occupy a similar basin on that side. During the epoch on which we are now entered these broad features apparently begin to be developed. Subsiding gulfs commenced to form on the east and west, with the Wisconsin axis projecting southward between them. While, therefore, limestone continued to be deposited, it was modified by these conditions. Over the low arch in the southern portion of the State there accumulated coarsegrained, rough, uneven-textured, thick-bedded, more or less cherty, and often breceiated, dolomitic deposits which have received the designation Galena limestone."*

One of the most characteristic features of the Galena limestone is the surface fissures which everywhere traverse the formation. Sometimes they are mere vertical cracks or horizontal partings of the strata, but often widen out into broad cavities. In these openings are found the lead and zinc ores of the region. The metallic ores taken from this limestone form perhaps one of the most important economic characters; and it was the Dubuque region

*Geol. Wisconsin, Vol. I., p. I65. Madison, IS79. 
in which the lead ore of the Upper Mississippi valley was first mined in a systematic way.

The Galena limestone furnishes a considerable quantity of good material for heavy masonry. The chief quarries are located at the city of Dubuque, though everywhere throughout its geological range the rocks are adapted and used for ordinary building purposes. A superior quality of lime is also manufactured from this rock.

MAQUOKETA SHALES.

Along the entire western slope of the Turkey river, and below the mouth of that stream on the Mississippi as far as Clinton county, there is exposed between the Galena limestone and the Niagara an extensive bed of bluish or greenish clay shales. Disintegrating readily under the influences of weathering, these shales allow the massive overlying dolomites to form a bold mural escarpment, which extends the entire length of the Turkey river. This escarpment sweeps around behind Dubuque at a distance of six or seven miles and strikes the Mississippi a short distance above Bellevue. The shales have not been reported north of the Iowa boundary. Beginning at a point in Winneshiek county about twenty miles from the Minnesota line the Maquoketa shales have a thickness of a dozen feet.or more. This thickness rapidly increases till at its southernmost exposure it attains a vertical measurement of more than 125 feet. At Dubuque a few feet of these shales are seen in isolated patches on the summit of the bluffs. For the most part these shales form alternating bands of dark and light colored clays with occasional thin seams of impure limestone. On the upper Maquoketa, where the typical locality is located, the shales are highly charged with many species 
of fossils. This formation is of small economic importance unless the clays can be utilized in the manufacture of brick and pottery.

UPPER SILURIAN LIMESTONES.

One of the most important topographical features of northeastern Iowa is what is known as the Niagara escarpment, which rises in bold prominence along the western slope of the Turkey river and continues southward along the Mississippi nearly to Davenport. The upper Silurian limestones in Iowa have a very considerable thickness. They are massive dolomites, yellowish or brown in color. Although presenting great uniformity in texture there are locally large amounts of cherty material in bands or irregular nodules. Silicious material is often seen disseminated in fine particles throughout the rocks, but for the most part it is concentrated into the masses already referred to.

Chemical analyses of the limestone itself show that most of the formation is a very pure magnesian limerock, or dolomite, with searcely any foreign material. In certain layers the percentage of lime and magnesia vary somewhat. In a few cases the latter is almost entirely wanting and the beds assume the phase of a normal limestone.

From its southern exposure, where it is thought to attain a thickness of perhaps 500 feet, it rapidly thins out northward until just beyond the Iowa-Minnesota line, where its vertical measurement is very insignifcant. At the southern end it is very heavily bedded. In many places the inclination of the beds is very considerable, sometimes as high as sixty degrees. Lying directly upon the inclined strata are often seen perfectly horizontal beds. (See plate iii. of the Quarry of the Sugar. Creek 
Lime Company.) At first sight it appears as if there were a marked unconformity. From the examination of some of the exposures it seems more probable that the apparent dip is in reality false bedding on a laige scale. In some cases it may, be that very decided disturbances have occurred in the strata.

The exact subdivisions of the upper Silurian rocks in Iowa are yet somewhat unsettled. Hall, in 1858, regarded the limestone as made up of an upper member which he termed the Le Claire limestone, and a lower portion, which was regarded as the same formation in New York to which the name Niagara had been applied. With the exception of White, all geologists who have examined the upper Silurian strata in Iowa regard these rocks as made up of at least two distinct formations. At present these subdivisions differ greatly, not only faunally, but in a less marked degree in their stratigraphical and lithological characters. For the reasons set forth above, Hall's Le Claire appears a desirable term for the upper member as now understood; while Niagara, for the present, will be retained for the lower member. For the latter term some other name will probably have to be substituted after a further investigation of these rocks has been made.

Uses.-Perhaps no other geological formation in the State furnishes a better quality of building stone for general purposes than the upper Silurian strata. A great extension of these rocks, both in thickness and surface area; make the supply inexhaustible. It forms, also, the best lime in the world. This industry in the State has already begun to assume very considerable proportions. The principal varieties of this rock, and its chief qualities, as reported by MaGee; ${ }^{*}$ are as.follows: "The portions exten1885 .

* toth Census U. S., Vol. .X.; Rep. Building Stones, p. 263. Washington, 


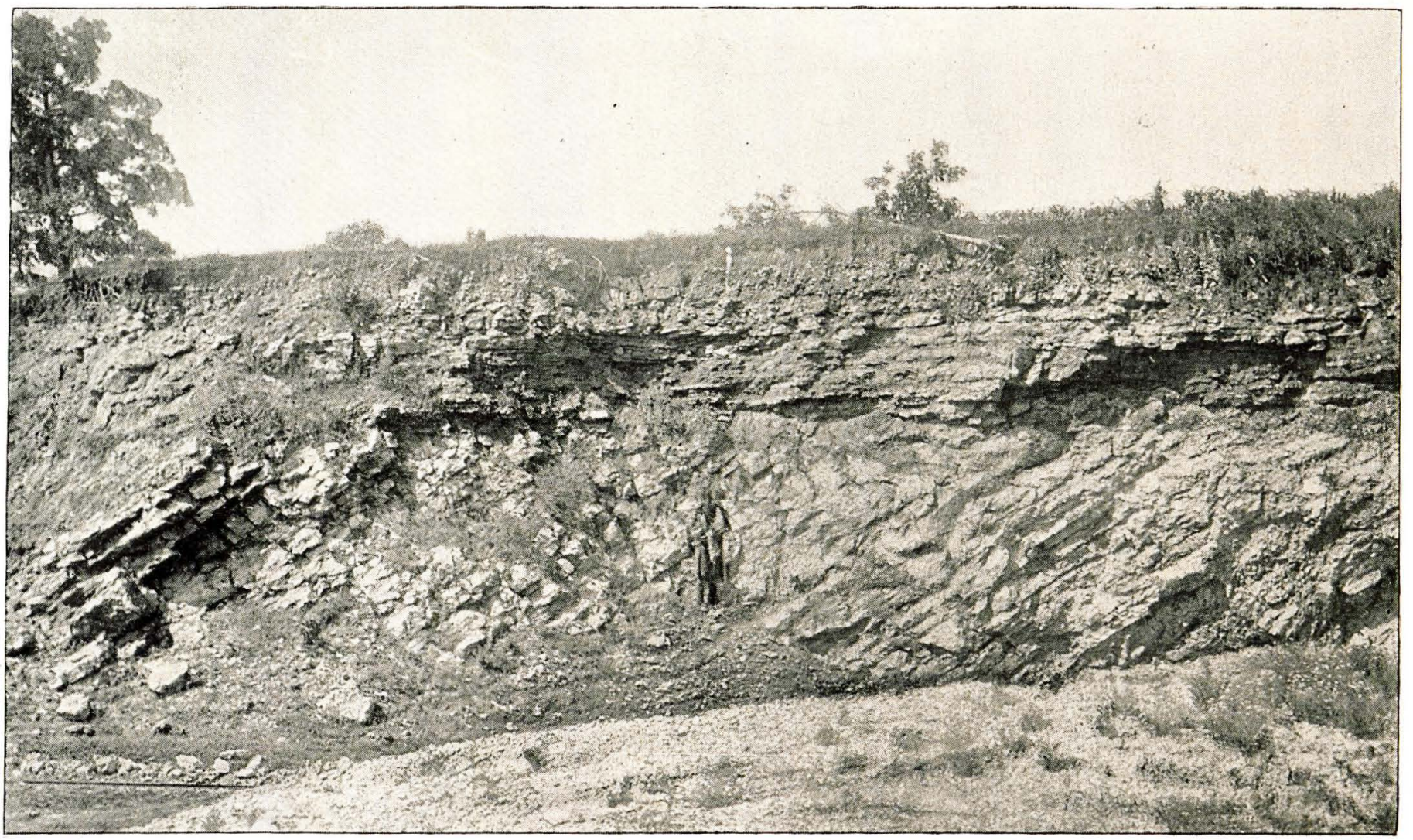

TILTED SILURIAN STRATA. 
. 
sively utilized for building material are either regularly and rather heavily bedded, and distinctly jointed, finely saccharoidal, homogeneous, and tough, and of buff, light brown, or whitish color, as at Farley, Le Claire, Littleport, Volga, Cascade, Clay Mills, Maquoketa (in part), .Buena Vista (in part), Princeton, and in most of the smaller quarries of Clayton, Dubuque, Jackson, and Scott counties; finely laminated horizontally, distantly jointed, and without dry seams, finely saccharoidal and tough, and of buff, yellowish, or whitish color, as at Anamosa, Stone City, Mount Vernon, Olin, Hale, Fairview, and BuenaVista (in part) ; heavily bedded or massive, distantly jointed, saccharoidal, moderately tough and firm and brown, brownish buff or brownish yellow in color, as at the Williams quarry (between Pottsville and Clermont), Waucoma, Cresco, Brainard, and Foreston; irregularly bedded and jointed, somewhat friable, finely vesicular, imperfectly homogeneous, and varying from brown to white in color, as at Clinton, Lyons, Comanche, and Sabula (in part); tolerably regularly but variably bedded and distantly jointed, though with occasional dry seams, firm, hard, and somewhat brittle, buff or light buff, with veinings of oxide of maganese, as at Delhi, Monticello, Central City, Maquoketa (in part), Sabula, De Witt, and Tipton ; or, finally, tolerably regularly bedded and not distantly jointed, fine, compact, homogeneous, brittle, and blue or light blue in color, as at Manchester, where alone this aspect has been seen. In nearly all of these places the rock discloses occasional dry seams which are generally straight, diagonal to the jointing, vertical and discontinuous, often terminating in both directions in a single block; which seams may be partially or wholly cemented by crystalline calcite or dolomite, generally stained with iron oxide, and never simulate fresh 
fractures. They are seldom abundant in large quarries, but are nearly everywhere a source of annoyance to the quarrymen, since they are most likely to occur in the larger blocks."

\section{DEVONIAN.}

The Devonian rocks of Iowa form a broad belt fifteen to twenty-five miles on each side of the Cedar river, and are made up chiefly of massive limestones with some dolomites. Although one of the most important geological formations in the State, its geology requires much additional investigation before it is clearly understood. Prof. $\mathrm{S}$. Calvin has given more attention to these rocks in Iowa than perhaps any other investigator. The following paragraphs on the Devonian of the State are taken chiefly from his notes. Four subdivisions of the Devonian will be here recognized as represented in Iowa. The Cedar Valley limestone probably will require further subdivision, as the name is applied to nearly all the limestone formations of Devonian age in the State. So much has been already said concerning the correlation of the Iowa Devonian beds with the eastern formations, and so great is 'the existing confusion, that no attempt will be made to name their equivalents in the New York section.

INDEPENDENCE SHALES.

These beds were firstinvestigated in 1878, in Buchanan county, by Professor Calvin. They consist of dark carbonaceous clay with thin bands of impure concretionary limestone. They were first exposed in working out the lower layers in the limestone quarries near Independence. The quarrymen penetrated the shales to a considerable depth in the hopes of finding coal. The shale varies somewhat lithologically, but where "it presents its most 
characteristic features it is argillaceous, fine-grained, and highly charged with bituminous matter. In some of the. beds there are remains of plants-stems of lepidodendrons and sigillarids-that made up the forests of the Devonian. The plants, however, are very imperfect, the form only being partially preserved, mainly by iron pyrite. The woody tissues of the plants have been converted into coal that occupies thin irregular seams among the laminse of pyrite. The little bands of coal vary in thickness, but: none of those observed exceed a quarter of an inch. None: of the plants are perfect enough to render generic or spe-. cific identification possible.

The discovery of shale charged with the carbonized. stems of plants below the Devonian limestone of Iowa is: a matter of much interest. Frequent reports have gained; circulation of discovery of coal in drilling wells in regions occupied by Devonian rocks. From Jesup, Janesville; Marion, Davenport, and other places, such rumors have: gone out. In one or two cases shafts have been dug at. considerable expense, necessarily ending in disappointment and failure.

The discovery at Independence accounts for these reports. In drilling through the limestones, the lower. shales, with their carbonized plants, were reached, and the dark color of the borings, mixed with fragments of real coal, naturally enough gave rise to the impression that a veritable coal mine had been found.

It is to be noticed that all the places from which such reports have come stand near the eastern outcrop of the Devonian, where its entire thickness could be pierced at a very moderate depth. The number and position of such localities would show that the shale in question is not a 
mere local deposit, but is distributed all along the outcrop of Devonian rocks in Iowa. A considerable number of fossils have been found in these shales.

It is an interesting fact that of the twelve determinable species of fossils found, six occur only in the shaley deposits at the opening and close of the Devonian, notwithstanding these deposits are separated by 150 feet of limestone. Only one species is known to pass from the lower shales into the limestones above, and even there it appears. under a form so altered that specimens from the two beds may be distinguished as readily as if they were distinct species. If we take form and surface markings into account, Atrypa reticularis of the beds in question also finds its nearest representative, not in the limestones immediately above, but in the shales at Rockford."

Obviously, then, the Independence shales are more nearly related to the Lime Greek beds than to any other formation in Iowa. The species in the basal member of the Iowa Devonian seem to have disappeared with the ushering in of conditions under which limestones were formed; they maintained themselves in some locality which has not been discovered, or from which the shaley deposits have been entirely swept away, and returned with the return of conditions favorable to their existence during: the deposition of the Lime Creek shales.

\section{CEDAR VALLEY LIMESTONES.}

The first geological name applied to the Devonian limestone of Iowa was that of Cedar Valley, given by Owen* in 1852. McGeet has so recently given a historical sketch of the taxonomy of this formation that it seems

${ }^{*}$ Rep. Geol. Sur. Wisconsin, Iowa, and Minnesota. 1852 .

tU. S. Geol. Sur., Irth Ann. Rep., p. 314. Washington, 1893. 
undesirable to give a fuller review of the subject in the present connection. His remarks are as follows :

"This formation is one of the most extensively distributed within the territory [of northeastern Iowa], and it is at the same time the most widely diverse in lithologic, paleontologic, and structural characters. 'Thirteen distinct lithologic phases have been enumerated elsewhere, ${ }^{*}$ and, as it will appear later, the paleontology is equally diverse. It consists predominately of limestones, ranging from pure to argillaceous, dolomitic, or perhaps carbonaceous ; sometimes it is regularly divided by smooth beddingplanes; again it is massive, elsewhere finely laminated, and frequently brecciated in a peculiar manner; sometimes the strata are horizontal, but elsewhere they are locally inclined to every point of the compass, and at all angles up to ten or fifteen degrees, and sometimes the mass is so richly fossiliferous that well preserved fossils may be collected by the bushel, while again it is quite destitute of fossils over wide areas. The thickness of the formation can only be estimated roughly, and the extent of the terrane cannot accurately be determined by reason of the heavy mantle of drift, particularly in the southivest.

The contact between the Cedar Valley limestone and the superjacent shales is nowhere well exhibited; neither is the contact between the Devonian formations and the overlying Lower Carboniferous anywhere clearly exposed. The outliers of the coal measures repose unconformably upon and fill cavities within the limestones at the known points of contact in Johnson, Muscatine, and Scott counties. The contact with the subjacent Niagara limestone is exposed at two points, namely, in the northwestern part of

${ }^{*}$ Rep. Ioth Census U. S., Vol. X, pp. 26I-263. Washington', 1884. 
Fayette, and in the left bluffs of the Wapsipinicon, be: tween Central City and Paris.

In 1858 Hall referred certain "gray and yellow sandstones, with shaley admixtures and shaley partings, which exist at numerous points on the Mississippi river, below Davenport," associated with the Devonian limestone, to the Chemung, * and at the same time he referred the limestones themselves to the Hamilton and the upper Helderberg, $\dagger$ and certain laminated shaley limestones underlying the latter to the Onondaga.f In 1860 White recognized the general equivalency, but denied the exact contemporaneity of the former beds with the Chemung, as developed in New York; $\$$ a year later Meek and Worthen referred at least a part of the same beds, which they designated as Kinderhook, $\|$ to the Carboniferous. Worthen retained the classification in 1868, 1 and in 1870 White referred all the Devonian strata of Iowa to the Hamilton..$^{*}$ Subsequently Hall and Whitfield investigated the Devonian rocks of the northern part of the State, and correlated the shale occurring at Rockford and Hackberry, and certain beds at Cedar Falls, with the Chemung, the limestones at Waterloo with the upper Helderberg, the white limestone at Raymond with the Schoharie, and the limestones and shales at Independence and Waverly with the Hamilton.t' After a study of the rocks and fossils extending for several years, Calvin, in 1878, called attention to the tripartition of the Iowa Devonian into

*Geol. Iowa, Vol. I, pp. 88-9I. 1858 .

†Ibid, pp. 81-85.

†Ibid, p. 76 .

?Jour. Nat. Hist. Soc., Vol. VII, pp. 209-226. Boston, 1860.

\|Geol. Sur. Illinois, Vol. I, p. rog. Springfield, 1866.

fiAm. Jour. Sci., (2), Vol. XXXII, pp. 173-228. New Haven, i86i.

$\dagger^{*}$ Geol. Iowa, Vol. I, p. $187 . \quad 1858$.

t†23rd Regent's Rep. New York State Cab. Nat. Hist., pp. 223-226. 1873 . 
the shales exposed on Lime creek, the great limestone series, and a dark shale found beneath the limestones at Independence and elsewhere; but he followed White in referring the three divisions to a single formationthe Hamilton.* In 1880 Barris pointed out that the Devonian strata at Davenport comprises a series of clearly differentiated beds with one or more unconformities; and that while one of the beds appears to correspond with the Hamilton of New York, the general affinities of the fauna of another seem to be with the fossils of the Corniferous or upper Helderberg. $\dagger$ A few years later, H. S. Williams, after an elaborate study of the Devonian faunas of the United States, concluded that the Lime Creek beds are "equivalents of the Chemung period deposits of the east;" $\ddagger$ and subsequently that "the exact relation of the Lime Creek beds and other deposits of the west is not satisfactorily determined."§ In the same year Calvin correlated anew the Iowa and New York faunas, noted new discoveries which "would seem to indicate that the Lime Creek beds are equivalent to the New York Chemung," but conceded that "the mingling of upper and lower Devonian features in the Lime Creek fauna, and in all the Devonian fauna as well, leaves the question of exact equivalency still doubtful."

Quite recently H. S. Williams has pointed out that - "the relation of the Rockford (Lime Greek) shale fauna and that of the yellow sandstones of Muscatine * * * is with the fauna of the Ithaca group of New York and the

*Am. Jour. Sci., (3), Vol. XV, pp. 460-462; and Bul. U. S. Geol. \& Geog. Surv. Terr., Vol. IV, p. 727, et seq. 1878 .

tProc. Davenport Acad. Sci., Vol. II, pp. 261 -269, and 282-288. I8so.

fAm. Jour Sci., (3), Vol. XXV, p. 163. 1883 .

乌̧Ibid, p. 31 .

||lbid, p. 436 . 
east,"* and since, as long since shown by Calvin, the faunas of the summital and basal shales of the Iowa Devonian are substantially identical, this reference applies equally to the subjacent limestones with their large and locally variable faunas.

The "gray and yellow sandstones" associated with the limèstones below Davenport, and near the present village of Buffalo, referred to the Chemung by Hall, in 1858, were supposed by him to be equivalent to the sandstones near Burlington, which were in 1861 shown by Meek and Worthen to be Carboniferous, and included in their Kinderhook formation ; $\dagger$ and White in 1870, accepting Hall's correlation of the Buffalo and Burlington sandstones, as well as the determination of the age of the latter by Meek and Worthen, referred the sandstones of Muscatine county to the Carboniferous; $\ddagger$ and Hall, $\S$ Williams, $\|$ and Calvin $\|$ accepted that reference. Recently, however, Calvin has reinvestigated the matter. He ascertained that the characteristic fossil of the Buffalo sandstones, Spirifera capax, is but an internal cast of Spirifera parryana, and showed that this fossil is associated with many other characteristic Devonian forms. These sandstones contain absolutely no Carboniferous remains, and thus it is demonstrated that these beds belong to the Devonian system, and probably to the Hamilton formation. $f^{*}$

So the Devonian rocks of Iowa have been referred to the Kinderhook, Chemung, Ithaca, Schoharie, Hamilton,

*Am. Geologist, Vol. III, p. 233. 1889 .

†Am. Jour. Sci., (2), Vol. XXXIII, pp. 173-228. I86r.

†Geol. Iowa, Vol. I, p. 189. 1870 .

\&Rept. State Geologist New York, pl. 52. 1882.

(IAm. Jour. Sci., (3), Vol. XXV, pp. 97-104. 1883 .

INotes on the Geological Formations of Iowa, p. 7. 1885.

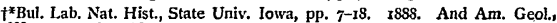
Vol. III, pp. 25-36. 18s9. 
Corniferous, and Upper Helderberg; and even if the question be narrowed by excluding the Hackberry shales and the Independence shales, and by accepting Calvin's correction of the erroneous reference of the Buffalo sandstones, it remains true that parts or all of the limestone series have been referred to the Chemung, the Schoharie, the Hamilton, the Corniferous, and the Upper Helderberg. Yet the stratigraphic relations of the fossiliferous beds generally indicate continuous deposition, the only noteworthy unconformity being that recognized at Davenport by Barris. ${ }^{*}$ It is therefore manifestly unwise to correlate either the limestones alone or the entire series of Devonian strata with any of the New York divisions; and while the shales may be discriminated on both lithologic and paleontologic grounds, it is not now possible (and perhaps it never will be possible) to separate the limestone series into distinct formations or into individualized beds of more than local value. They-may accordingly be treated as a unit, and may take an individual name; and it seems expedient to recur to the designation originally proposed by Owen, and rechristen the entire series of calcareous Devonian sediments stretching from the Minnesota line to Muscatine county, in a belt fifty miles in average width, the Cedar Valley limestone."

Uses.--Some of the most valuable building and ornamental stones occurring in Iowa are of Devonian age. Perhaps the best limestones for heavy masonry are those quarried on the Iowa river, about ten miles north of Iowa City. The old State House at Iowa City, and the basement of the new Capitol building at Des Moines were constructed of this rock. Unlimited quantities of good building stone are accessible in the Devonian rocks throughout their exposed

*Proc. Dav. Acad. Sci., Vol. II, p. 265. IS8o. 
area. Abundant supplies for the manufacture of quick lime are present everywhere, but the quality of lime is not as good as that furnished by the Upper Silurian strata. The character of the quarry rock is shown in the accompanying view. (Plate iv.)

\section{MONTPELIER SANDSTONE.}

One of the most important geological problems that has been solved in Iowa of recent years is the correct determination of the geological age of certain arenaceous beds in Muscatine county. This sandstone had been correlated with beds exposed fifty miles to the southward in the vicinity of Burlington, Iowa. The latter were subsequently found to belong to the lower Carboniferous, and it was taken for granted that the Muscatine beds were also of the same age; consequently they have all been referred to the Kinderhook epoch. Galvin * has recently found a very extensive fauna in the Muscatine county sandstones referred to the Kinderhook. The fossils are all characteristic Devonian species.

$\therefore$ "The Hamilton limestone of Buffalo, with its peculiar association of fossils, disappears beneath the level of the river at ordinary stages a short distance below Montpelier, in Nuscatine county. The last seen of it in that immediate region is a low ledge or reef exposed at low water, and running out into the Mississippi river a hundred yards or more, at a point almost directly in front of the pressent residence of $\mathrm{Mr}$. G. W. Robinson. If, however, the bank of the Mississippi is followed, there is found, a short distance above the mouth of Pine creek, an exposure of yellowish sandstone with interstratified shaley beds. The position of this sandstone leaves no doubt as to its rela-

*Am. Geologist, Vol. III, pp. 25-36. Minneapolis, rsSg. 
IOWA GEOLOGICAL SURVEY.

PLATE IV.

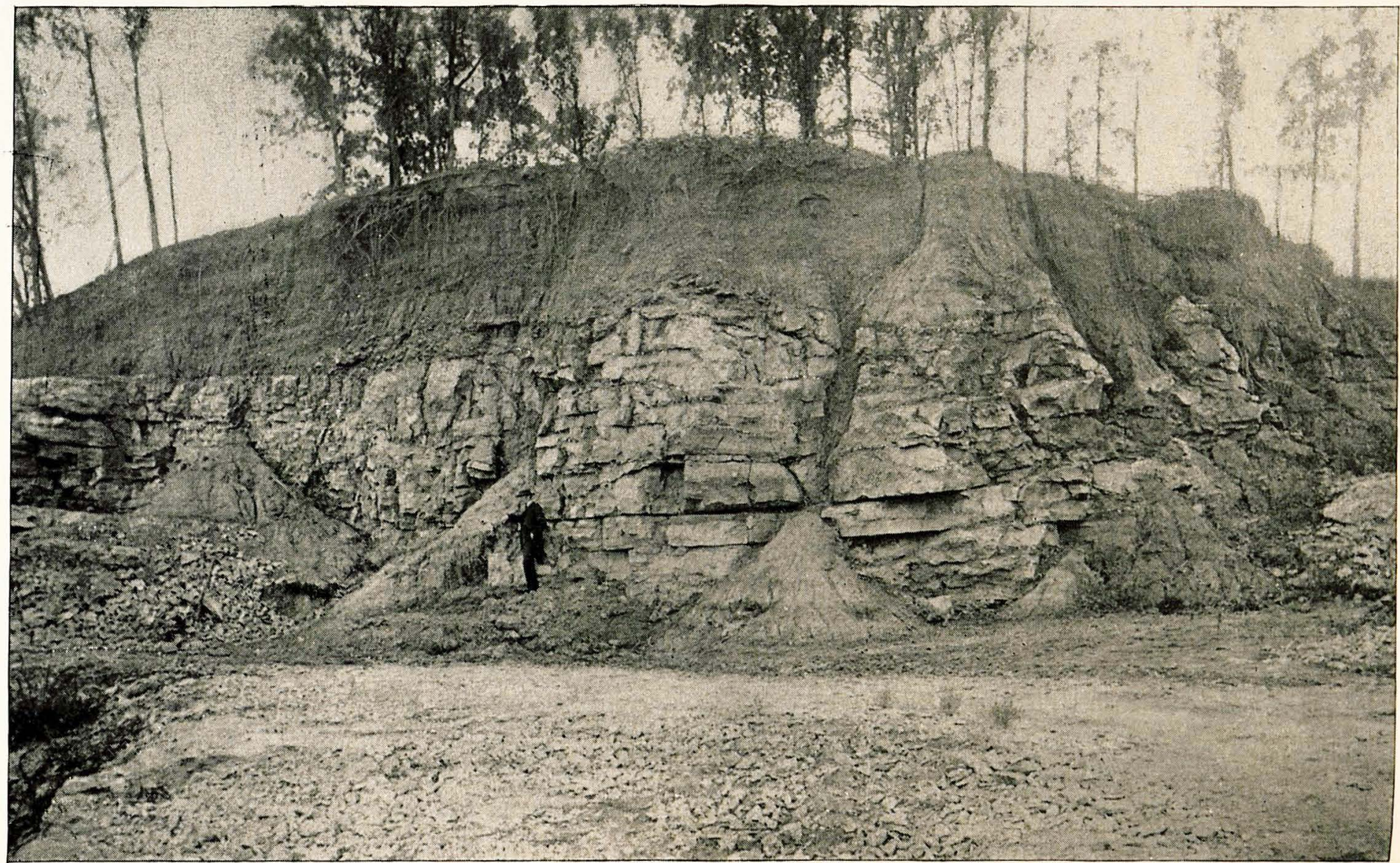

DEVONIAN LIMESTONE, IOWA CITY. 

tions to the Hamilton limestone. Although along the river the contact is not seen, the sandstone is evidently superimposed on the limestone.

Up to the present time no one, so far as is known, has called into question the propriety of assigning the yellow sandstones above the mouth of Pine creek, in Muscatine county, to the same horizon as the yellow sandstones at Burlington. Hall's statement as to their equivalency has been accepted as final, and when the sandstones of Burlington were transferred from the Chemung period to the Subcarboniferous, by common consent, the Spirifer-bearing sandstones of Muscatine county were supposed to be similarly transferred. White speaks of the Kinderhook beds as striking the Mississippi river at Muscatine.

Repeated excursions have been made to the region near the mouth of Pine ereek, attracted first by unusual facilities offered for collecting beautifully preserved casts of the so-called Spirifery capax, and afterward by the desire to study anew the stratigraphical phenomena of the region. A very casual study of the facts now available in determining the geological problems of the region in question is sufficient to demonstrate that the Spirifer-bearing sandstone at Pine creek is not the stratigraphical equivalent of the Kinderhook sandstone at Burlington. The two sandstones do not belong to the same period, nor do they even belong to the same age. More than a thousand specimens of Spirifera capax have been handled, the specimens occurring in the form of casts in the supposed Kinderhook sandstone. Impressions of the external surface of the shell are often very perfectly preserved, revealing every detail of surface-marking. From the study of such an array of material, showing every phase and character of the species, there can be but one conclusion, and that is 
that Spirifera capax is simply the cast of Spirifera parryana Hall, a species more or less common in the limestones at Buffalo-limestones that Hall, and Owen, and Shumard, with the full concurrence of all geologists who have examined the region, referred to the horizon of the Hamilton group of New York.

Associated with the casts of Spirifera parryana ( $S$. capax) in the sandstones about Pine creek, occur the casts of such typical Devonian species as Atrypa reticularis Linn., Spirifera aspera Hall, Strophodonta demissa Conrad, Orthis impressa or Orthis iowensis Hall and many. other well known brachipods. There is not a single Kinderhook species in the entire beds, so far as observed, nor is there a species that could by any stretch or reasonable allowance be regarded as a representative of any of the Carboniferous groups. On the contrary, all the species are identical with species occurring in the Hamilton limestones at Buffalo, Pine Creek Mills, Hanson's quarry at Atalissa and all other points where limestone containing Spirifera parryana is exposed.

The yellow sandstones above the mouth of Pine creek, therefore, are of the same age as the limestones near Buffalo. They are not even Chemung unless the limestones are also Chemung; much less are they Lower Carboniferous or Kinderhook.

No Kinderhook or Lower Carboniferous of any kind has yet been observed in the region above Pine creek, in Muscatine county. A very complete section of the rocks of the region may be studied in the bed and banks of Robinson's creek, a small stream emptying into the Mississippi a short distance below Montpelier. Near the mouth of the creek is the ledge of limestone already mentioned as exposed at low water; and extending out into 
the river for more than a hundred yards. This limestone is the same as that found at Hanson's quarry, Pine Creek Mills, and many other points, and is characterized by the presence, among others, of the following fossil species: Spirifera parryana, S. aspera, Atrypa reticularis, and Athyris vittata. Following up the channel of Robinson's creek is found (1) beds of arenaceous shale* with some thin beds of limestone, containing branching polyzoa, Atrypa reticularis, Strophodonta demissa, very large forms, and Orthis iowensis; (2) argillaceous shale only a few feet in thickness containing no fossils; (3) layers of sandstone, among which is a bed about fourteen inches in thickness, containing casts of Spirifera parryana (S. capax), with which are associated, either in the same bed or in adjacent beds both above and below, casts of Atrypareticularis, Strophodonta demissa, Orthis iowensis, and Spirifera aspera; (4) a considerable thickness of sandstones containing no fossils as far as observed; (5) arenaceous beds containing casts or impressions of corals related to Cladopora, and impressions of what seem to be immense masses of Stromatopora; (6) a bed of fragmentary materials interstratified with irregularly interrupted flexuous beds of shales and sandstones varying greatly in thickness and spread over the uneven and apparently eroded surface of the underlying sandstone; (7) flexuous beds of shale, with a bed of impure coal from two to three feet in thickness; (8) evenly bedded friable sandstone varying in color from yellow to gray, and containing in some of its layers numerous impressions of Calamites, Sigillaria and Lepidodendron. Casts of the stems of Lepidodendron apparently of the species recognized by Owen as L. aculcatum

\footnotetext{
* No opportunity has yet been found to measure the thickness of the several members of the section.
} 
Sternberg* yere observed more than nine inches in diameter.

The beds 1-5 are of Devonian age and must all be referred to the same period as the limestones at Buffalo and Pine Greek Mills. Beds 6, 7, and 8 are of much later origin; they belong to the Carboniferous period and were probably contemporaneous with the Upper Coal Measures of southwestern Iowa.

Practically the same succession of strata as seen in Robinson's creek may be observed in what is known as railroad quarry at Montpelier. An immense quantity of stone was taken out by the railway company and used as riprapping to protect the embankment from the wash of the river. The magnitude of the work performed here may be inferred from the fact that the riprapping extends sometimes for miles continuously as far as Muscatine. The beds worked were Devonian sandstone, the equivalents of 3,4 , and 5 of the section along Robinson's creek. The Spirifer-bearing layer is here about two feet in thickness; it is harder than at the localities on Robinson's creek or on the river above the mouth of Pine creek, and it would seem to have furnished a very large proportion of the material used in riprapping. At the upper end the Coal Measure shales and sandstones are seen resting unconformably on the Devonian sandstones. The lower beds are very flexuous and distorted. A well-marked layer at any point may thin out and disappear in a distance of twenty feet. The conglomerate bed-number 6-on Robinson's creek is here well marked, the fragmentary materials being interstratified with irregularly contorted beds of shale and sandstone disposed at all imaginable angles and frequently thinning out within a few feet. At one point observed in

${ }^{*}$ Geol. Sur. Wris.; Iowa, and Minn., tab. vi, figs. I-2. 1852 . 
the face of the bluff the conglomerate bed had a thickness of eight or ten feet, while only a short distance to the left the same layer had thinned to eight or ten inches. In the face of the bluffs, at a height of about fifteen feet, occurs a layer of impure coal about ten inches in thickness, and above the coal are regular horizontal, even-bedded layers of sandstones representing number 8, on Robinson's creek. Below the coal seam all the strata are confused, contorted, irregular; above the coal seam the layers are even, regular, and horizontal.

There are two distinct sandstones belonging to different ages in the region about Pine creek and Montpelier, in Muscatine county, Iowa. One belongs to the Middle Devonian, the other to the Lower Coal Measures. To avoid confusion I have used at different times in this article the term Spirifer-bearing sandstone, to denote the earlier of the two. They must be spoken of hereafter respectively as Devonian and Carboniferous sandstones.

The Devonian sandstone, as developed at and near Montpelier, seems not to have a very wide geographical distribution. The conditions favoring its deposition were evidently local. In the particular locality affected by them. these conditions, whatever they may have been, operated disastrously on most of the Devonian fauna. During a part of the time, however, Spirifera parryana found the conditions unusually favorable. The great number of casts of this species occurring in the Spirifer-bearing layer would indicate that the sea-bottom was fairly crowded for: a time with large, healthy, vigorous individuals, and that the species occupied the region to the almost total exclusion of everything else. Spirifcra aspera, the constant associate of S. purryuna in the underlying limestones, is almost entirely absent, only two or three specimens of $S$. 
aspera being seen among many hundreds of S. parryana. Even Atrypa reticularis, that most ubiquitous of all Devonian brachiopods, apparently capable of living anywhere and under any circumstances; was represented by a comparatively few widely scattered individuals. The Orthis iovensis attained a larger size than usual, but the number of individuals was small. Athyris vittata, which is one of the most abundant shells in the subjacent limestones, is unrepresented in collections from the sandstone: In the fossiliferous portion of the sandstone, individuals of Strophodonta demissa are about as numerous as in the limestone.

It is only in one layer, and that not very thick, that Spirifera parryana occurs. Some of the species mentioned persisted after $S$. parryana abandoned the struggle. They range a foot or two above the Spirifer bed, but brachiopod life soon ceased, and the sandstone through several feet of its thickness shows no traces of fossils.

There is but a single fish tooth in the collections from the sandstone, and it is apparently identical with an undetermined species occurring in the Hamilton limestone at Solon and Iowa City.".

LIME CREEK SHALES.

This formation is well exposed in a number of localities in Floyd county chiefly, the most important, perhaps, being at Rockford and along lime creek. There is exposed a vertical thickness of about 100 feet of rather dark colored argillaceous shales which are highly fossiliferous. They disintegrate rapidly under the influences of the weather, forming a very plastic clay which is quite yaluable for manufacturing brick. The geographic extension of these shales is not known at present, nor is their strati- 
graphic position fully understood. It seems best, therefore, to retain for them the name which is usually applied to them, since the title of Rockford, has proved to be unavailable.

\section{CARBONIFEROUS.}

The Lower Carboniferous, or Mississippian Series.

The great series of limestone lying at the base of the Carboniferous in the Mississippi valley is in Iowa one of the most important geologieal formations exposed within the limits of the State. The part lying in Iowa occupies a very small portion of the entire area covered by this. rock in the Mississippi province. This succession of Carboniferous limestones forms a more or less continuous. belt, exposed in broad tracts, from northern Iowa to Alabama and from Ohio to New Mexico.

For this lower calcareous portion the term "Subcarboniferous" has been applied usually; but, as will be seen hereafter, there are serious objections to this name. "Mississippiar Series" has therefore been employed as a substitute in the present connection. The name was originally suggested in nearly this sense by Alexander Winchell, and has recently been somewhat modified by H. S. Williams.*

More than half a century has passed since the rich and varied faunas of the later Paleozoic rocks of the continental interior first began to attract attention. From the beginning an exceedingly active and ever growing interest was. taken in the various forms of ancient life represented, and as a matter of consequence the geological history of theregion was approached from the biological rather than the stratigraphical side. Especially was this the case-

*Bul. U, S. Geol. Sur., No. 8o, p. 135. Washington, 1891. 
along the line of the Mississippi river, where the most important exposures of the strata in question occur.

The relations of the most important horizons of the Lower Carboniferous in the Upper Mississippi valley were early made out by Owen and others, and although Owen's views underwent considerable change during the dozen years he was engaged in studying these rocks, his subdivisions have been practically the basis of all subsequent classifications. In the main they have been adopted everywhere, notwithstanding the fact that considerable diversity of opinion has existed in respect to the minor stratigraphical details.

In the naming of the several assemblages of beds, the leading and most widely known terms that have been applied have been taken from localities situated on the "Father of Waters." The Mississippi section therefore becomes the most important of all in the correlation of the Lower Carboniferous rocks of the great interior basin. For this reason it was that recently all the original localities were visited, the various exposures examined in detail, their relationships with each other and with the overlying and underlying strata particularly noted.

The nominal history of the major subdivisions of the Paleozoic in the Mississippi basin need not be reviewed in this place. Suffice it to mention that the term Subcarboniferous had in the beginning a very different meaning from what it has had of late years. As originally proposed by Owen, ${ }^{*}$ the name was used merely to indicate the indefinite series of limestones below the coal-bearing strata of the continental interior. Subsequently the same-author limited the formation below to the blue fossil-bearing

*Rept. Geol. Rec. Indiana, p. 12. 1837. (1839.)

†Rep. Min. Lands of the U. S., p. 14 . 1840. 
limestones now known as the Cincinnati beds. It was in 1847 , when Owen and Norwood" gave the "black slates" as the upper limiting member of the Devonian, that "Subcarboniferous" was still farther restricted, thus for the first time giving the name Subcarboniferous the meaning which has been generally attached to it of late years.

The most familiar names assigned to the subdivisions of the Carboniferous along the Mississippi river are ten in number, viz.: Choutean, Kinderhook, Burlington, Keokuk, Warsaw, Saint Louis, Ste. Genevieve, Chester, Kaskaskia, and Coal Measures.

The Lower Carboniferous rocks in Iowa occupy a sinuous belt twenty-five to forty or more miles in width, midway between the Cedar and Des Moines rivers. They thus extend from the southeastern corner northwestward to the boundary of the State. Narrow tongues of Lower Carboniferous rocks are also exposed along the Skunk and Des Moines rivers, extending up the latter to within about thirty miles of the city of Des Moines.

Immediately under the loose surface deposits this formation is found extending over the following counties, wholly or in part: Lee, Des Moines, Henry, Jefferson, Van Buren, Louisa, Washington, Keokuk, Iowa, Poweshiek, Marshall, Tama, Grundy, Hardin, Butler, Franklin, Cerro Gordo, Wright, Humboldt, Hamilton and Webster. Narrow strips are also exposed in Wapello, Mahaska, Marion and Pocahontas counties.

The most important section of the Lower Carboniferous rocks is exposed along the Mississippi river from below Muscatine to Cape Girardeau, a short distance above the

\footnotetext{
*Researches on the Protozoic and Carb. Rocks of Central Kentucky during the year i846. 1847 .
} 
mouth of the Ohio. Along this line the section is almost. continuous. The entire limestone is a fossiliferous one. The typical outcrops of the different subdivisions of the formation. were originally described from exposures along this stream. The section of the Mississippi, therefore, becomes the most important one of all in the region under consideration. As exposed on the great river, along the eastern boundary of Iowa, the Iower Carboniferous rooks below Burlington dip rapidly to the southward, but begin to rise again near Keokuk; they thus form a shallow syncline, with its lowest point a few miles below Fort Madison.

As based upon the best lithological, stratigraphical, and faunal evidence-now at hand, the classification of the Lower Carboniferous or Mississippian series along the line of the principal section, that is, along the line of the Mississippi river, is as follows:

\begin{tabular}{l|l|l}
\hline & Kaskaskia. & $\begin{array}{l}\text { "Chester shales." } \\
\text { "Kaskaskia limestone." } \\
\text { Aux Vases sandstone. }\end{array}$ \\
\hline $\begin{array}{c}\text { MISSISSIPPIAN } \\
\text { SERIES }\end{array}$ & St. Louis. & $\begin{array}{l}\text { Ste. Genevieve limestone. } \\
\text { Saint Louis limestone. } \\
\text { Warsaw limestone (in part not typical). }\end{array}$ \\
\hline & Augusta. & $\begin{array}{l}\text { Warsaw shales and limestone (typical). } \\
\text { "Geode bed." } \\
\text { Keokuk limestone. } \\
\text { Upper Burlington limestone. } \\
\text { Lower Burlington limestone. }\end{array}$ \\
\hline Kinderhook. & $\begin{array}{l}\text { Chouteau limestone. } \\
\text { Hannibal shales. } \\
\text { Louisiana limestone. }\end{array}$ \\
\hline
\end{tabular}

KINJERHOOK BEIS.

Heretofore the propriety of regarding the lower Carboniferous rocks of the Mississippi basin below the Bur- 
lington limestone as a distinct subdivision of the section has been generally conceded, and the upper line of demarkation is easily recognizable throughout its geographical extent. Its lower limit, however, has not been made out satisfactorily over the entire area of its occurrence; but in many. places the group of strata is known to rest on the "black shale" so well. developed in Tennessee, and generally regarded as Devonian in age. For the group of beds in question, or parts of the group, various names have been given. But their historical consideration need not be dwelt upon at length here. Whatever may be eventually the most appropriate term to apply to this section, it seems advisable for the present to retain Meek and Worthen's name for these rocks as exposed along the line of the Mississippi river.

Among the earliest references to the rocks of this group in the continental interior is that made in connection with Owen's explorations in southeastern Iowa.* This author called some sixty feet of ash-colored shales, exposed above the level of the water in the Mississippi river to the base of the encrinital limestone at Burlington, the "argillo-calcareous group," and regarded it as belonging to the lower part of the Subcarboniferous. These shales were actually a portion of the median member of what Swallow in Missouri had termed the "Chemung" group. This group was divided into (1) the Chouteau limestone, (2) the Vermicular sandstone and shales, and (3) the Lithographic limestone. Within the limits of the region under consideration the three divisions are quite persistent and easily recognizable over a wide area. For present convenience the last two members may be termed more appropriately

*Geol. Sur. Wisconsin, Iowa, and Minnesota, p. 92. 1852.

†Ann. Rep. Geol. Sur. Mlissouri, p. 103. 1855. 
the Hannibal shales and the Louisiana limestone respectively, since at these places in northeastern Missouri they are exposed in their full development.

Throughout Iowa, Illinois and Missouri, at least, and perhaps in other states also, wherever the Kinderhook rocks are exposed, its members, as here designated, will always be recognized to a greater or less extent, particularly in faunal studies. Over all the three states named these subdivisions are sharply defined lithologically, except possibly toward the northern known limits, though there these rocks have received very little or no attention. At the present time it seems very probable that the third or lowest member-the Louisiana or Lithographic limestonewill find a closer relationship with the Devonian than with the Carboniferous, and that eventually it will be regarded as the capping stratum of the former over all the territory contiguous to the Mississippi.

In $1858 \mathrm{Hall}$ still continued to regard the Burlington (Iowa) section below the oolite layer as Chemung. But he also included in the group some yellow sandstones occurring fifty miles to the northward, which Calvin* has recently proved conclusively to be of Devonian age.

Although Owen had referred the shales lying immediately below the limestone at Burlington, Iowa, to the Subcarboniferous (limited) more than a decade previously, Meek and Worthen, $f$ in 1861, were the first to prove beyond a doubt that the faunas of the rocks along the Mississippi river between the cities of Burlington and Saint Louis, and lying between the "black shales" and the Burlington limestone, have much closer affinities with those of the overlying strata than with those below, and there-

*Am, Geologist, Vol. III, p. $25 . \quad 1889$.

†Am. Jour. Sci., (2), Vol. XXXII, p. 228 . 1861. 
fore the rocks in question properly belong to the Lower Carboniferous series. The name "Kinderhook" was then proposed for the formation.

Soon after, Worthen* published further details, especially in regard to the typical locality, Kinderhook, Illinois. Various sections in the neighborhood were fully described, leaving no doubt as to the real limits that were intended to be assigned to the terrane. On the opposite side of the river, in Missouri, the exposures are almost. continuous for more than thirty miles, and show well the relations of the beds from the "black shales" to the upper division of the Burlington limestone.

In the Iowa section Whitef recognized as Kinderhook the rocks exposed at the city of Burlington, previously called Chemung, together with a few feet of what was once considered as belonging to the superimposed stratum.

The "Chouteau" group takes its name from the leading member of the three-fold division, the Chouteau limestone. The application in this sense was first made by Broadhead, $f$ who used the term to cover the same limits as Swallow's "Chemung" in the earlier Missouri reports. Very recently the name apparently has been extended by Williams $\$$ to embrace also the lower Carboniferous littoral deposits (Waverly grits, etc.), as well as the more open sea deposits of argillaceous and calcareous material (Kinderhook shales and limestone).

From the foregoing it appears that in the states bordering the Mississippi river the term Kinderhook has priority in the naming of the lower member of the Lower

*Geol. Sur. Illinois, Vol. I, p. 10S. 1866.

†Geology Iowa, Vol. I, p. 192. I870.

†Geol. Sur. Missouri, p. 26. 1874 .

§Bul. U. S. Geol. Sur., No. 80, p. $169 . \quad$ I8gr. 
Carboniferous, as now generally understood. Whether or not. Waverly or Marshall, as the rocks of probably the same age in Ohio and Michigan are called, should replace Meek and Worthen's name, remains to be seen. These probably represent the littoral deposits of the more westerly limestones just referred to. Both lithologically and faunally they are sufficiently distinct from the western deposits to make a separate designation desirable, at least for the present.

As has been seen, the Kinderhook is, as at present understood, a three-fold division, comprising:

(3) Chouteau limestone.

(2) Hannibal shales.

(1) Louisiana limestone.

Louisiana Limestone.-The lowermost of these formations-the Louisiana limestone-is not exposed at the surface within the limits of Iowa. It is the Lithographic limestone of Sivallow. At Louisiana, in Pike county, Missouri, it attains a thickness of more than sixty feet. For a long time this lime-rock has been regarded as the basal member of the lower Carboniferous in northeastern Missouri and western Illinois. In the former state many fossils have been described from these beds. . The fossils contained have recently been found to be restricted chiefly to a thin, sandy seam, not more than four inches in thickness, and lying at the very base of the limestone. As the fossils contained in this thin layer appear to have a very distinct Devonian facies, it has been recently suggested* that the sandy seam cannot be regarded as a part of the lower Carboniferous. The limestone itself rarely contains fossils, and the few forms that have been found have been

*The Present Basal Line of Delimitation of the Carboniferous in Northwestern Missouri: Am. Geologist, Vol. X, pp. $3^{80-384 . ~} \quad$ ISg2. 
so few and scattered that the exact geological age of the Louisiana limestone must now be regarded as somewhat doubtful.

Borings at Keokuk seem to indicate that there are at least ten feet of this rock represented about 200 feet below the water level of the Mississippi at that point.

Hannibal Shales.-These are the Vermicular sand; stones and shales of Swallow in his Missouri report. At Hannibal, seventy-five miles south of the Iowa line, the shales have a thickness of about seventy feet. The upper portion is made up of sandy material which in places passes into compact sandrock. This sandy portion rapidly loses its arenaceous character downward, passing into bluish or greenish clay-shales which appear to be remarkably uniform over broad areas. At Burlington, Iowa, more than seventy feet of these blue and somewhat indurated layers are to be seen above low water in the Mississippi. Borings indicate a thickness considerbly more than twice the figure just mentioned.

Lithologically this formation as exposed at Burlington is a massive, somewhat sandy clay-shale; often highly calcareous and in the upper part contains silicious matter in the form of a fine yellow sand, which occasionally assumes the character of a soft sandstone. Below the sandy portion these shales have long been supposed to be destitute of fossils, but late exposures in places have disclosed faunas of a most interesting and instructive nature. A short distance below Burlington, near the mouth of the Skunk river, the beds disappear below the water level. At Keokuk, as has been shown by recent borings, they are in the neighborhood of 150 feet below low water in the Mississippi. At Burlington, as will be seen by reference to the section at that place given farther.on, 
immediately below the Burlington limestone are several beds, a few feet in thickness; made up of limestone and oolite which are separated by clay shales. The exact relation of these beds to the Missouri section is not known at present. Beyond the immediate vicinity of the Mississippi river the shales are not exposed at the surface in Iowa, but they apparently have a considerable geographical extent, and are thought to be recognizable in a number of deep well sections in different parts. of southeastern Iowa.

Chouteau Limestone.-At Hannibal and Louisiana, in Missouri, the upper member of the Kinderhook is a finegrained, compact limestone, buff in color and usually more or less impure from an admixture of clay material. South and westward from the localities just mentioned it rapidly thickens until it attains a vertical thickness of more than $\mathbf{1 0 0}$ feet. Northward it thins out rapidly. It may be represented at Burlington by a few feet of buff calcareous layers lying at the base of the great limestone at that place. This division may also include an oolitic bed at the same place.

Kinderhook Limestone of Central Iowa.-A hundred miles northwest of Burlington, in Tama and Marshall counties, rocks referred to the Kinderhook are well exposed along the Iowa river and some of its tributaries. The exact correlation of these beds with those of southeastern Iowa has not yet been fully made out. As shown in the Le Grand quarries the rock is chiefly a rather soft, somewhat irregularly bedded, buff limestone, probably 
containing a considerable percentage of magnesia. The section at Le Grand is as follows :

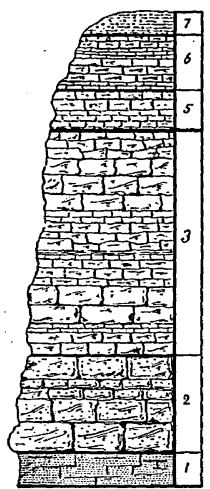

Figure t.
Drift

4.

Rather heavily bedded brown limestone, "sub. crystalline' 10.

Very fine-grained limestone, breaking with conchoidal fracture .................... 7 Chert band

Buff magnesian limestone, heavily bedded, fine-grained and containing many fossils in certain layers ..................... 40.

Gray oolite, "heavily bedded and highly fossiliferous .

Blue calcareous sandstone, heavily bedded above (exposed)

It seems very probable from an examination of the fossils contained in the Le Grand beds that a part at least of the layers correspond to the Burlington limestone in southeastern Iowa. There are indications also that some of the Le Grand strata are to be correlated with the more typical Kinderhook; these same beds are reported by White as occurring on the west branch of the Des Moines, in Humboldt county.

Uses.-In southeastern Iowa no good quarry rocks have been found in the Kinderhook formation. Occasionally the oolitic beds are used, but withstand weathering only for a short time. The clay shales at Burlington have recently been brought into prominence in the manufacture of paving brick. 


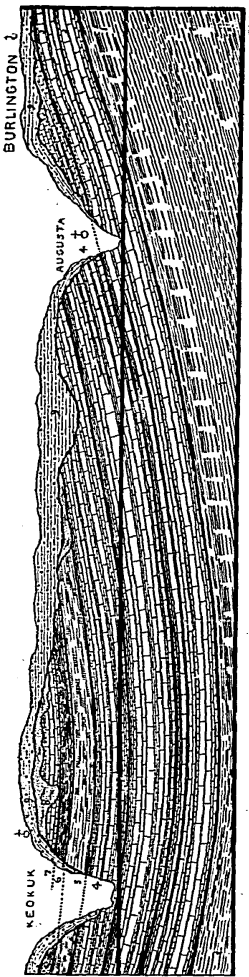

Toward the northern limit in Iowa the Kinderhook, as has been already stated, assumes a calcareous facies. : It is extensively quarried at numerous places, the most important being $\mathrm{Humboldt}$ and Dakota City, in Humboldt county; Iowa Falls, in Hardin county; Conrad, in Grundy county; Tama, Le Grand and Toledo, in Tama county; and Quarry and Dillon, in Marshall county. In Marshall and Tama counties this fine-grained, buff, magnesian limestone forms a very durable building stone. It has been used largely for bridge piers, architectural purposes a and ordinary rough masonry. Portions of it contain numerous narrow veins stained with ferric-oxide. It takes a fairly good polish and is extensively used for inside work in place of ordinary marble, Considerable quantities have been shipped to eastern cities, giving good satisfaction. The lower part of the Le Grand section is made up of a very compact oolitic limerock. It withstands very. well the weathering in- 
fluences, as is shown in the court house at Marshalltown, which is constructed almost entirely of this stone.

\section{AUGUSTA LIMESTONE.}

This term is applied to those rocks exposed in the Mississippi valley which have heretofore been called the Burlington and Keokuk limestones. The typical localities of these two so-called formations are the cities of the same names in the southeastern part of the State. These rocks are exposed in an almost continuous section along the Mississippi river from a point above Burlington to the mouth of.the Des Moines. (See figure 2.) The Burlington and Keokuk limestones, titles which have long been used to designate certain rocks of this region, have been shown ${ }^{*}$ to belong principally to a single formation. Upon purely paleontological grounds as well as for stratigraphical reasons the two limestones should be included under a single term, at least in the vicinity of the Mississippi river where the typical exposures occur. The advisability of including the upper and lower Burlington limestones and the Keokuk under a single head was pointed out in a paper published in September, 1889, entitled "Carboniferous Echinodermata of the Mississippi Basin." At that time it was thought inadvisable to propose a new name for this formation, until further investigations had been made southward from the original locality, and the exact relations made out between the rocks as shown in the latter places and those of the adjoining regions referred to the same geological age. In the meanwhile Williamst suggested for this limestone the title "Osage," from the name of the chief river of southwestern Missouri which cuts through

*Keyes: Am. Jour. Sci., (3), Vol. XXXVIII, pp. 186-193. New Haven, i889.

†BuI. U. S. Geol. Sur., No. 8o, p. rog. Washington, rSgr. 
some of the Lower Carboniferous series in Saint Clair county. As stated in the more recent publications in which this term has appeared, Osage has been used for the Burlington and Keokuk rocks of Missouri only provisionally-until more detailed information was obtainable. The term Osage does not now appear to be applicable, in the sense that it was originally proposed, to the rocks of the Mississippi basin under consideration. The Osage river, from which the name is taken, flows for a greater part of its length through limestones of the great Ozark series (Cambrian or Lower Silurian). The upper part of the river passes through Coal Measure beds almost entirely. Only a very small portion of the watercourse touches the Lower Carboniferous at all. The "Osage country," by all Missourians especially, is a term applied to the region along the lower part of this stream. At Osceola, where the most typical section of the "Osage" is exposed, the rocks appear to be as typical Burlington as at the city of Burlington itself. Recent visits have disclosed no Keokuk whatever at the place in question. One of the chief reasons for proposing Osage was that the beds of southwestern Missouri were thought to contain a mingling of faunas of both Burlington and Keokuk beds. In so far as personal observation goes, the Kinderhook, Burlington, and Keokuk beds are as sharply contrasted lithologically, faunally, and stratigraphically as in southeastern Iowa. From the foregoing it would seem that the "Osage" formation at its typical locality is practically coextensive, and therefore synonymous, with the Burlington limestone. Southeastern Iowa has long been regarded as the typical locality of the rocks under consideration. There these beds have been described more in detail and are better understood than in any other region 



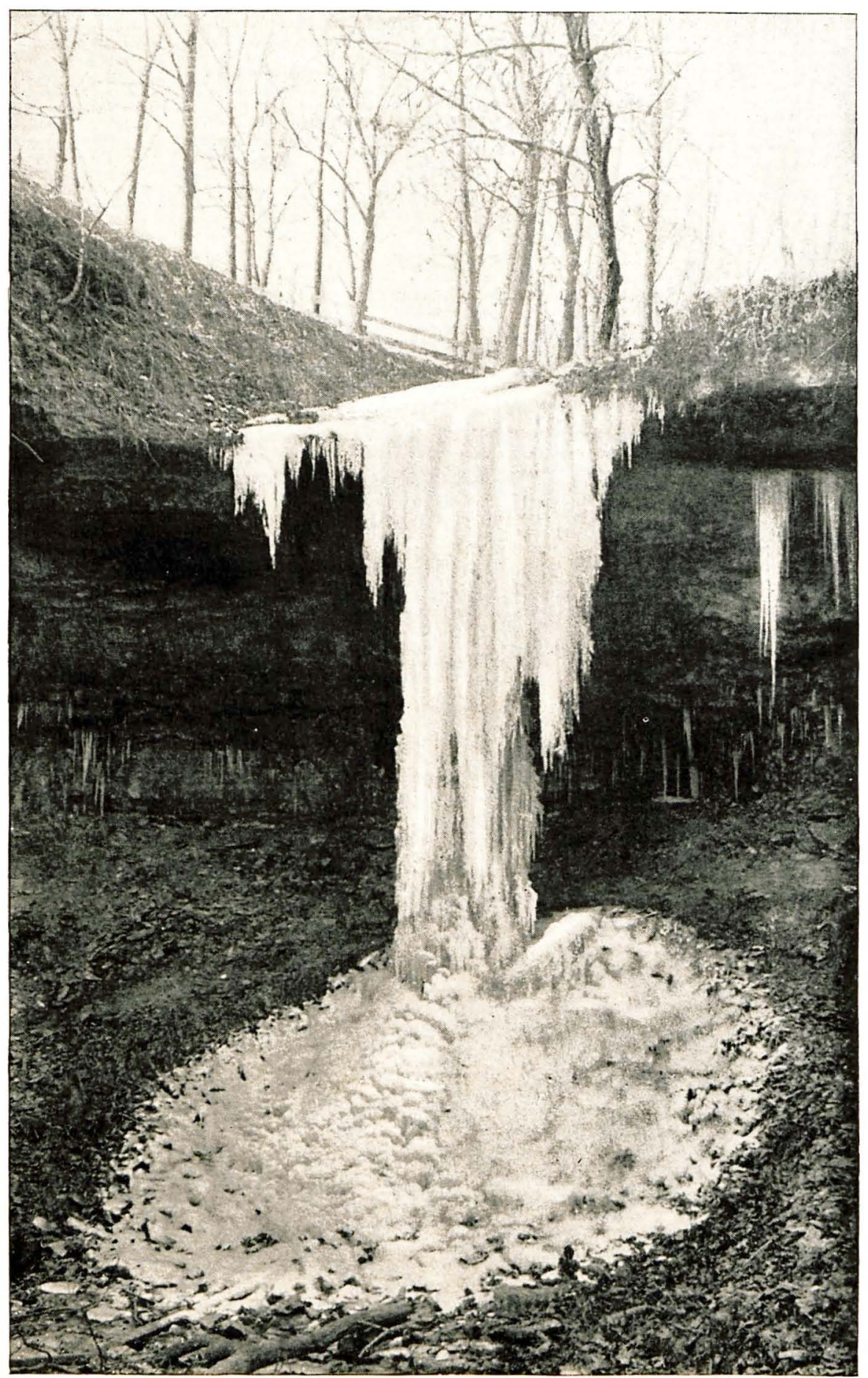

THE "CASCADE," BURLINGTON. 
in which they occur. Since the Burlington and Keokuk limestones manifestly form a single epoch in the geological history of the region, as has been conclusively shown a number of times recently; since a term applicable to these rocks as a whole is desirable; and since the name "Osage" is apparently unavailable, it appears best to suggest for the title of this terrane the name of some locality in southeastern Iowa where the rocks are well exposed. Along the Skunk river in the vicinity of Augusta, about ten miles southwest of Burlington, there is exposed the entire succession of these rocks from the Kinderhook shales to the "geode bed." (See figure 2.) This name, therefore, seems more appropriate to use than perhaps some other better known term. Good exposures of the formation are found all along the Mississippi river from Keokuk to Burlington, as already mentioned. The limestone often stands out in overhanging cliffs over the softer Kinderhook beds, as is well shown in the vicinity of Burlington and elsewhere. (Plate v:)

Owen's Encrinital limestone embraces practically the same beds that were afterwards called the Burlington; and his lower Archimedes corresponds to Hall's Keokuk group; below the "geode bed." Shumard seems to have used the term " Encrinital limestone" in a variety of senses-sometimes referring to the Burlington alone, sometimes to both Burlington and Keokuk, and often to the Burlington and part of the Keokuk. Partly on lithological grounds, buit chiefly for paleontological reasons, the "Augusta". may be regarded as made up of three members-upper, middle, and lower, coinciding essentiilly with the Keokuk and the upper and lower Burlington limestones. In regard to the fossils of the thirce horizons the most conspicuous differ- 
ences were first suggested by White ${ }^{*}$ and quite recently $\dagger$ they have received further attention.

During the deposition of the lower Carboniferous rocks, life throughout the interior of North America was remarkable for the immense development and expansion of piscine and echinodermatous types; and among the latter, especially, for the culmination of crinoidal and-blastoidal forms. Not only was the development of the Crinoids phenomenal in the number of species, but the extensive numerical representation of individuals was most astonishing. Many species had an extensive distribution, but the large majority were very limited in space, and especially in time. Those species, therefore, which experienced a wide dispersion form valuable and reliaable criteria for synchronizing horizons far removed from one another. The equivalency, however, of strata of distant localities can at best be only approximately determined from paleontological data alone. As has been suggested by Williamst the biologic sequence in any limited region is not indicative of the genetic succession of the inhabitants, but merely the sequence of occupants within that particular area. The gradual oscillation and change of habitat to which the Carboniferous echinoderms of the Mississippi basin were subjected would tend to make their migrations extend through longer periods of time, and their specific existence more protracted than the stratigraphy of any one place would indicate. And thus certain species would become extinct in one region and be completely replaced by very different forms, while in dis-

*Jour. Boston Soc. Nat. Hist., Vol. VII, pp. 224-225. I860.. †Keyes: Am. Jour. Sci., (3), Vol. XXXVIII, pp. 191-192. 1889. $\ddagger$ Pro. Am. Ass. Ad. Sci., Vol. XXXIV, p. 232. I885 $_{5}$. 
tant localities the migratory species would continue to flourish in all their wonted vigor.

Echinodermatous life during the Lower Carboniferous was preëminently crinoidal and blastoidal; the former greatly predominating in the earlier part and the latter conspicuously present in the later portion of the period. So marked is the contrast between the faunal features of the middle and upper portions of the Lower Carboniferous that Wachsmuth and Springer* have suggested that. the Burlington and Keokuk deposits could very appropriately be called the "Crinoidal limestone," while the Saint. Louis and Chester are manifestly a "blastoidal" division.

A synoptical table has been arranged of the Carboniferous genera of echinoderms and their distribution during Paleozoic time. The generic groups enumerated, while characteristically Carboniferous for the most part, are very unequally distributed in time. In nearly every instance each genus exhibits (1) a gradual expansion after its first appearance, shown by the differentiation of species occurring in each epoch ; (2) a culmination marked not only by a large number of species and a great numerical increase of individuals, but also by a remarkable development and specialization of various structural characters and by a more or less wide distribution in space; and (3) a decrease in the number of species, and a very apparent decline in physical energy, generally terminating in a more or less abrupt extinction of the group. The culmination of crinoidal life generally was in the middle of the Lower Carboniferous. At the close of the Augusta epoch one-half of the Carboniferous genera had become extinct. The great group Camerata had passed away, with the exception

*Proc. Acad. Nat. Sci., Phila., p. $229 . \quad 1878$. 
of the Hexacrinidæe and a few depauperate forms of several other genera whose existence was quickly brought to a close. A large proportion of the genera in the extensive section Inadunata had disappeared. Of those groups which survived to the close of the period, a diminutive species Allagecrinus (a single specimen only being at present known) was the sole representative of the branch Larviformia; while of the great group Fistulata only the typical genus (including four subgenera) of the Poteriocrinidæe extended through the entire Lower Carboniferous. And the widely distributed Calceocrinus, which began back in the lower Silurian, became extinct just before the beginning of the Saint Louis.

Wachsmuth and Springer ${ }^{*}$ have shown that in the expansion and geological development of the various groups of crinoids the modification of specific characters was very gradual, and corresponded in a striking manner with the changes by growth in the individual. Another suggestive fact is that usually the more generalized types of the various groups are the more persistent, often having a considerable range, both in time and space. The expansion of the several families is also frequently indicated by the relatively rapid development, in some supra-generic groups, of certain structural features which soon become curiously differentiated. Perhaps nowhere in any zoological group is its culmination better or more clearly defined in accordance with the suggestions already made, than in the Crinoidea. The remarkable multiplicity of specific and generic types appearing in rapid succession during the middle Lower Carboniferous; the extreme and phenomenal specialization of particular anatomical structures; the great

*Proc. Acad. Nat. Sci., Phila., p. 229.1878. 
increase in size; the ponderous character of the test; and the marked structural changes in many minor particulars are of peculiar biological significance. Toward the close of the Augusta epoch nearly all the specialized forms became extinct, and with a very few exceptions only the more generalized types continued through the Lower Carboniferous-only such forms as were ordinally related to living crinoids.

If the crinoids formed a prominent faunal feature of the earlier part of the lower Carboniferous, the blastoids were equally conspicuous during the latter portion of the period.

From a comparison of the Crinoidea occurring in the upper and lower Burlington and Keokuk limestones it is quite apparent, as first observed by White* and afterwards more fully discussed by Wachsmuth and Springer, $\uparrow$ that the forms of the three horizons present some marked differences. Those species from the lower Burlington are of small size, delicately constructed and ornamented; in the upper Burlington the peculiar delicacy that is so marked in the lower bed forms is absent or has assumed a ruder character; while in the Keokuk the crinoids are characterized by large size, rough, massive construction, bold, rugged ornamentation and a conspicuous exaggeration in many structural details. The last consideration is of great interest. For it appears that in general the exaggeration of various structural features is indicative of important biologic changes in that particular zoological group in which such extreme developments take place; and as has been shown in other orders, this extravagant and undue acceleration in growth is relatively very rapid,

*Jour. Boston Soc. Nat. Hist., Vol. VII, pp. 224-225.

tLoc. cit.

5 G. Rep. 
but of short duration, and usually terminates in the abrupt extinction of the group; or, as in some cases, results in a . very distinct diminution of vitality. It would seem, then, that a general amplification of the various anatomical structures in any faunal group marks its culmination; and this fact is peculiarly significant in its application to fossil crinoids, for the middle of the Lower Carboniferous was pre-eminently the climax of crinoidal life.

The abrupt extinction of a large proportion of crinoidal forms towards the close of the Augusta is certainly suggestive of a series of decided and widespread changes in the geographic and bathymetric extent of the great interior sea: White* has already shown that at least in some portions of the Mississippi basin there were very considerable alterations in the coastal contour of this broad, shallow gulf during the latter part of the Lower Carboniferous, and it is known that there were even greater changes in the coast line in the other parts of this region during the same period. During the Keokuk the waters over portions of Iowa, Illinois, Missouri and Indiana, became greatly diminished in depth, and the land of the same area was considerably extended. While the Saint Louis beds were being deposited the sea again encroached upon the land, extending in some places more than 200 miles northward, beyond the former Keokuk waters. Over an extensive portion of the interior sea the conditions of environment during the Keokuk and Saint Louis epochs presented some notable differences, as is amply attested by even a casual comparison of the fauna of the two divisions. In some parts of Indiana and Illinois the organic remains of the former are characterized by a certain luxuriancy of individual growth, apparent not only in one, but

*Geology Iowa, Vol. I, p. 225. , 1870. 
in the majority of the zoological groups represented. In the latter diyision the animal forms in many cases are strikingly depauperate. It is not only a depauperation among a few types that is discernable, but a great diminution in vitality is manifest in forms genetically related to those occurring in the Keokuk.

As indicated in the general section, the Augusta limestone has been differentiated into five beds: Warsaw shales (typical), "geode bed," Keokuk limestone, Upper and Lower Burlington limestones. This has notbeen done upon lithological or stratigraphical grounds, but for purely paleontological reasons. As has already been seen, the formation is truly a single limestone, and the faunas contained are practically identical. The limestone is essentially a crinoidal one, though in its upper part this feature is not as marked as toward the base. That part now known as the Burlington is throughout the region the same coarse-.. grained, encrinital limestone, usually white, and quite pure in certain layers. The basal portion, known as the Lower Burlington limestone, usually contains considerable ferric oxide, and consequently has a characteristic reddish hue on weathered faces. The lithological characters of the Burlington are remarkably constant over broad strips of territory. They have been traced from northeastern Iowa to western Illinois, to southwestern Missouri and Arkansas. East of the Mississippi the typical exposures of this rock are unimportant, and the sections are confined to the vicinity of the great water-course. The division lines of the two Burlington limestones and of the Keokuk are marked by silicious beds. The lowermost of these chert beds has a thickness of twenty to twenty-five feet. It is made up largely of nodular masses and irregular beds of flint, with some calcareous matter. The upper chert 
bed, the one between the Burlington and Keokuk limestones, was reported by Hall to be upwards of 100 feet in thickness. Recent observation goes to show, however, that it probably has a no greater importance than the lower chert bed. Accurate records of borings indicate that the entire thickness of the Augusta beds-from the top of the "Warsaw" to the bottom of the Burlington-is not over 225 feet. Wherever the Augusta limestone is exposed along the Mississippi, north of the Missouri river, it stands out over the soft Kinderhook shales in rugged overhanging cliffs or high walls. At Burlington the basal line is marked by heavy layers of limestone, which often project to a distance of twenty or thirty feet. The small streams flowing over the limestone break into cascades twenty-five to fifty feet in height.

The upper Burlington division differs from the lower in its lithological characters chiefly by being more thinly bedded and containing layers of argillaceous shales. The Burlington beds are exposed in a number of places north of Burlington, on the Iowa river. Near Columbus, in Louisa county, good sections are exposed yielding large numbers of characteristic fossils. A few beds of the Le Grand quarries in Marshall county are supposed to belong to this formation.

The Keokuk beds are distributed chiefly on the east side of the "Father of Waters," covering a wide area in Illinois, Indiana, Kentucky and Tennessee. West of the river the best exposures are in southeastern Iowa and northeastern Missouri. At the typical locality the Keokuk beds consist of gray encrinital limestone with considerable chert, in layers or nodules. The lower portion is a heavily bedded, compact limerock having a bluish cast. The 
upper part is composed of clay shales with calcareous bands.

The vertical section of the rocks at Keokuk is as follows :

8. Soft brown or yellowish sandstone, passing into a fine-grained conglomerate in places, irregularly cross-bedded, and lying unconformably upon the next (exposed)

7. Blue and ash-colored, brecciated limestone, indistinctiy bedded locally and passing elsewhere into regular layers................. 25

6. Brown, impure, arenaceous limestone, heavily bedded............ 4

5. Blue, calcareous, clayey shales ................................... ro

4. Impure limestone, massive and weathering brown................ 7

3. Clay-shales, with occasional limestone bands-and abundant little crystal grottoes-the "geode-bed"............................... 35

2. Thinly bedded, somewhat shaley limestone.................... 5

1. Blue, encrinital limestone, heavily bedded and more or less highly - fossiliferous (exposed)

Below number 4 of this section is the Keokik group of Hall ; 4 to 6 , inclusive, form the Varsaw of the same author; while number 7 is the Saint Louis limestone reposing unconformably upon the brown massive layer, - number 6, and with the Coal Measures, number 8, superimposed unconformably upon it.

The Warsaw beds, as defined by Hall* and as exposed at the village of Warsaw, Illinois, are composed of (1) ten feet of compact buff-colored limestone, (2) thirty feet of blue calcareous shales with many thin limestone seams, and (3) eight feet of yellow arenaceous limestone. At Keokuk, five miles above, all three layers are thinner, and at neighboring places they exhibit still different characters. Southward, the beds lose their argillaceous nature, and appear not to be separable from the associated limestone. These layers, together with the "geode bed," which is usually consid-

${ }^{*}$ Geol. Iowa, Vol. I, p. 97. Albany, 1858 . 
ered the upper member of the Keokuk, may be regarded as mere local developments to which little importance is to be attached. In a quarry a short distance northwest of Rand Park, at Keokuk, Iowa, there is a good exposure, showing the upper surface of the buff arenaceous limestone to be water-worn and weathered; and directly upon the eroded rock rests twenty feet of brecciated limestone. Whether or not this can be regarded as a portion of an ancient land surface, older than the Saint Louis limestone, depends partly upon the results of further investigation and partly upon the final decision as to the origin of the brecciated rock.

At Hall's typical locality it is manifest that the Warsaw beds are properly the superior portion of the Keokuk limestone. This inference is directly derivable from the faunal and stratigraphical features, and in a less marked degree from the lithological characters of the deposits. The layers passing under this name reported from other localities are now known to have various relationships with the overlying and underlying strata. Alleged faunal peculiarities have usually been the chief grounds for considering the IVarsaw as a distinct subdivision of the Lower Carboniferous. Most writers on the subject have united the beds under discussion with the Saint Louis; a few with the Keokuk. This difference of opinion has arisen largely from the assumiptions made at the place most thoroughly studied by the respective authors, without due allowance being made for the varying conditions in separated localities. A careful comparison of notes and a somewhat extended study in the field show that the term "Warsaw" has been loosely applied since its original appearance as a geological name. In the majority of, cases the so-called Warsaw is clearly the lower part of the Saint Louis 
limestone. Thus the writers above alluded to were perfectly correct in contending that the "Warsaw," as they understood it, was really a portion of the Saint Louis. But it is a mistake to claim that the "Warsaw" of all localities is Saint Louis. It is apparent, then, that in some places the so-called Warsaw cannot be separated from the Saint Louis limestone; in other it is best united with the Keokuk. It seems better, therefore, to drop the term in its application to a distinct section of the Lower Carboniferous, or Mississippian series, with a rank equal to the other subdivisions here recognized.

Uses.-The Augusta limestones are quarried rather extensively, the chief localities being at Columbus Junction, Burlington and vicinity, Fort Madison, Keokuk, Bonaparte, Bentonsport and Keosanqua. The rocks at Burlingtoin are used for ordinary masonry, some of the layers, the more massive ones, forming a fairly good material for building. A good quality of lime could be manufactured, but at the present time only one or two small kilns are in operation. Farther southward the Burlington limestone is quarried in large quantities for the manufacture of lime as well as for ordinary masonry. The lower layers at Keokuk have been used for bridge work and all kinds of common masonry. A good quality of lime is burned in various places in the vicinities of the towns just mentioned. The sandy magnesian layers at the top of the Keokuk limestone have been used extensively for building, and a number of churches and other structures are composed of this material. Along the Des Moines river the rocks of this formation were formerly used largely in the construction of dams at the time when slack-water navigation was proposed for the Des Moines river. 
SAINT LOUIS LIMESTONE.

The light, ash-colored limestones occurring in Iowa, and now known under the name of Saint Louis, were first mentioned by Owen under the title of Concretionary limestone. Near the mouth of the Missouri river, where these rocks attain a much greater development, Shumard gave them the name of the leading place in the region. Since this recognition by Shumard, little difficulty has been' encountered in locating the Saint Louis limestone over a wide stretch of comntry. Its northern border is several hundred miles beyond any known exposure of Keokuk rocks. From this limit nearly to the mouth of the Missouri river the limestone is quite thin, but southward it rapidly thickens until in Ste. Genevieve county, Missouri, it attains a measurement of more than 300 feet, and still farther southeastward more than double the thickness known in the state mentioned. Everywhere over the northern area of the Saint Louis a characteristic brecciated rock is observable, but south of the Missouri river evenly bedded limerocks are present, with occasional extensive beds of oolite.

In Iowa the Saint Louis has probably a surface exposure much greater than any other member of the Lower Carboniferous. Its outcrops are abindant throughout the southeastern portion of the State, and extend westward along the Skunk and Des Moines rivers to within thirty. miles of the city of Des Moines. North of the last outcrop mentioned these rocks do not appear again at the surface until the vieinity of Ames is reached. It is also well exposed in the neighborhood of Fort Dodge:

Lithologically the base of this limestone is generally a. well-marked breccia, made up of a very fine-grained, compact, blue limestone, which breaks with a conchoidal frac- 
ture. The fragments are angular and vary in size from a few inches to several feet. The interstices are filled with a ' clayey, calcareous material which is usually much softer than the limestone, and in weathering allows the limestone boulders to project far beyond the matrix. Above the brecciated portion of this limestone the strata are laid down very irregularly, but upward rapidly pass into evenly bedded layers. (Figure 3.)

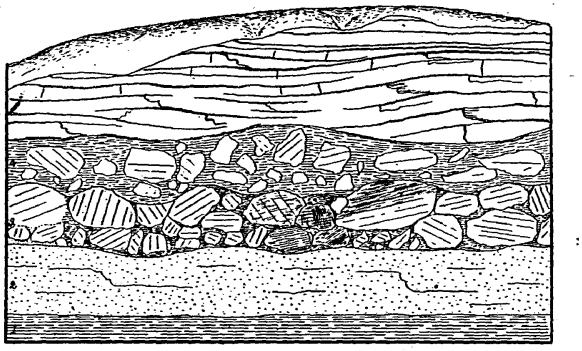

Figure 3. Base of the Saint Louis limestone at Keokuk.

Capping the Saint Louis limestone is often seen ten to twenty feet of white calcareous marl, which is usually highly fossiliferous. Some of the best exposures of this plastic upper member of the Saint Louis are to be seen near Fort Dodge, in the north-central part of the State, at Harvey and Tracey, in Marion county. In many places this marl had been completely eroded previous to the deposition of the coal measures. At Elk Cliff, a few miles from Harvey, as well as elsewhere in the vicinity, the coal measure strata rest directly upon the hard limestone. (Plate viii.) The unevenly eroded surface of the Saint Louis limestone 
will be referred to farther on, in connection with the re- marks on the unconformity of the Coal Measures upon the Lower Carboniferous. The thinness of the limestone already alluded to is due partly to the thinning out of the strata northward and partly to subærial erosion previous to the laying down of the Coal Measures in the region. The faunal features of the Saint Louis are very peculiar in many respects, and quite different from those of both the overlying and underlying strata, particularly of the latter.

Uses.-The Saint Louis limestone is made up largely of pure calcium carbonate. Quick-lime is manufactured at numerous places throughout the range of the formation. The limestone is also quarried for ordinary masonry. At Tracey and elsewhere in Marion county, and in Wapello and Van Buren counties, certain layers of the Saint Louis limestone furnish excellent material for heavy constructional purposes, bridge piers and foundations.

$$
\text { ĶASKaSkia, OR “ChESTER," BEDS. }
$$

Although no part of Iowa appears to have rocks. belonging to the upper member of the Lower Carboniferous, the formation is of particular interest, inasmuch as throughout the present area of Iowa the Kaskaskia epoch represents a long period of erosion. In southern Missouri and Illinois this formation is a triple division. The basal portion has been called the Aux Vases sandstone. In southern Illinois and southeastern Missouri the Kaskaskia comprises extensive beds of limestone and shale. Everywhere over this district the calcareous portions, which greatly predominate in the lower part of the group, are underlaid by a fine-grained, ferruginous sandrock. This sandstone is said to be recognizable above the city of Saint Louis, where it is a dozen feet or more in thickness ; south- 
ward it rapidly thickens until in the vicinity of the typical locality it attains a maximum measurement of more than 100 feet.

The true significance of this great sandstone separating the Saint Louis and Kaskaskia limestones does not appear heretofore to have been understood fully, especially when taken in connection with the absence of Kaskaskia rocks north of the Missouri river. Here is an extension of limestone-the Saint Louis-that before the Coal Measures were laid down was greatly eroded over a large part of its area, and over another adjoining portion having a great sandstone superimposed. This would seem to indicate that the broad expanse of water which during the deposition of the Saint Louis beds reached nearly to the present northern boundaries of Iowa, had retreated more than 400 miles to the southward. Dry land existed over a large part of the area formerly covered by the Saint Louis waters, and bordering this continental mass arenaceous deposits were laid down in the shallow littoral waters.

In all the Carboniferous of the Mississippi basin, therefore, no group of strata appears to form a better defined natural geological unit than those rocks commonly passing under the name of Kaskaskia or Chester.

The great arenaceous deposit lying at the base of the Kaskaskia limestone has been termed the "ferruginous sandstone" by Shumard and others. Many observers, however, have confounded it with a lithologically similar sandrock situated at the base of the Coal Measures, which as is well known, is located upon, instead of under, the Kaskaskia. For convenience, in reference, and to avoid further confusion, this great sandstone will be called here the Aux Vases sandstone, from the river of that name in Ste. Genevieve county, Missouri, on which the rock is ex- 
posed. Of course, in northern Missouri and Iown, where the superior member of the Mississippian series is wanting, the basal sandrock of the Coal Measures occupies apparently the same stratigraphical position as the lower Kaskaskia sandstone, that is, directly superimposed upon the Saint Louis.

The Kaskaskia limestone proper is composed of heavily bedded limestones below, and of plastic elay-shales, with thin calcareous bands, above. Everywhere over those portions of the upper Mississippi valley in which the Kaskaskia is absent the Saint Louis rocks, as already stated, are weathered and deeply channeled, many gorges passing downward even into the Keokuk, thus showing pretty conclusively that these portions of the territory were actually above sea-level during a part of the Kaskaskia deposition. That the northern shore-line continued to move southward after the Kaskaskia epoch had begun, and perhaps even until the latter half of the period had set in, is shown by the successive attenuations of the several beds and by the deeply excavated ravines, where were laid down the local deposits of sandstones and shales of the Coal Measures. In a number of cases, at least, these hardened sand accumulations, lying in narrow gorges, have been regarded erroneously as local depositions of Kaskaskia grit, intercalated in the shales and limestone. Furthermore, these consolidated sands contain plant remains, and inasmuch as they have been considered as part of the Kaskaskia, it is quite probable that this will account for some of the reported discoveries of terrestrial floras in the rocks of the Mississippian series.

Faunally, and especially stratigraphically, the Kaskaskia, as displayed everywhere over a broad area adjacent to the line of the principal section, appears separated fiv.. 
the Saint Louis far more widely than any other two members of the entire lower Carboniferous in the continental interior.

The term "Chester" has been used by some authors for the beds here designated as Kaskaskia. There seems to be, however, but little doubt that the latter name was published several years before Chester made its appearance in print. To be sure, Worthen, while an assistant of Norwood on the geological survey of Illinois, did suggest, orally or in his manuscript notes, as early as 1853, the name "Chester" for the beds in question; but the name was known for several years only to members of Norwood's corps, as Worthen himself says.* It was at least a dozen years later before the term was published with definite stratigraphical significance, and then with the full knowledge that it covered the same ground as Hall's "Kaskaskia." Hall, as early as 1856, read a paper before the Albany Institute, in which he proposed a classification of the lower Carboniferous of the Mississippi basin; and two years later he published essentially the same scheme in his Iowa report, $\dot{\dagger}$ accompanied by a clear description of this formation. Kaskaskia must necessarily be retained, therefore, for the upper member of the Mississippian series in preference to "Chester." If it is desirable to keep the lațter term in geological nomenclature, it might be advisable to restrict it to the upper shaley division, which can advantageously be distinguished from the lower massive limestones, and "Chester shales," as they are now often called locally, could still be made a useful term.

*Geol. Sur. Illinois, Vol. I, p. 41. IS66.

fGeol. Jowa, Vol. 1. p. 109 . ${ }^{1 S 5^{\circ}}$. 
The Present Classification of the Lower Carboniferous.

From the foregoing considerations of the different members of the Lower Carboniferous or Mississippian, it is to be inferred that on the best lithological, stratigraphical and faunal evidence now at hand, the series embraces four groups. These and their various subdivisions that have been recognized from time to time, are tabulated on page 50. The names given in quotation marks are local applications. The Kaskaskia, aside from the basal sandstone, appears to be a well-defined, two-fold division, and it seems advisable to keep the two members distinct, though special names are not retained for them here. The Saint Louis and Kaskaskia correspond essentially to Williams' "Ste. Genevieve group."

The great abundance of fossils in all of the members of the Mississippian series of the interior basin, makes the faunal test perhaps the most important of all in attempting a rational classification of the rocks of the region. Heretofore the remains of ancient life found in these rocks have been considered either from a purely biological point of view, or, in the majority of cases, from the standpoint of the mere species-maker; and it is only within the past few years that large numbers of species taken together have been compared with one another in order to marshal the confused hosts into orderly arrangement, so that faunas may be studied as a whole.

The second important consideration to be taken into account in the present connection is the stratigraphical testimony. In the case of the Kaskaskia the physical breaks are unusually prominent both above and below, over its entire extent, in the upper Mississippi valley. What has just been said of the upper member of the series is 
equally true of the one immediately underlying, though in a less marked degree, and over only a part of its superficial occurrence. Between the lower two groups the physical continuity is scarcely broken, and the separation is chiefly upon faunal and lithologic grounds.

Lithologically the upper two members of the Mississippian are more alike than any of the others; yet as a rule they are readily tistinguishable everywhere. The Augusta is over all its range encrinital, and stands out in marked contrast with the other three sections; while the lower subdivision is very different again, both in the calcareous and the argillaceous portions.

In regard to the minor subdivisions of the four groups above mentioned, much might be said. The several sectional names proposed at various times have had wide values, and, moreoyer, have been applied rather loosely.

In the Kaskaskia the upper shales and the lower limestones of Chester, Illinois, have been differentiated, while the Aux Vases sandstone has been placed at the base of the group provisionally. It has not had, as yet, sufficient study over its entire exposure to satisfactorily consider its relationship in all its phases. Certain it is, however, that when the continental area north of the present city of Saint Louis was being subjected to denundation prior to the deposition of the lower Coal Measures the great sandstone was laid down south of that point in the shallow littoral waters of the interior sea.

The Saint Louis group has been divided into three - limestones. Of these the Ste. Genevieve has never come into general usage, and practically has been forgotten. The Saint Louis limestone itself has been widely recognized, and inmany places the lower portions have been corre- 
lated with the Warsaw beds as developed at the mouth of the Des Moines river.

The Augusta group is now made to include all five of the hitherto recognized beds, the Warsaw proper, the "geode" layer, the Keokuk and the upper and lower Burlington limestones.

The Kinderhook group is a three-fold division whose several members are strongly contrasted and persistent over wide areas.

Upper Carboniferous, or Pennsylvanian Series.

\section{(Coal Measures.)}

General Considerations.-The coal bearing strata of Iowa form the northernmost extension of the great interior coal field of the American continent. This basin comprisès northwestern Kentucky, southwestern Indiana, southern and central Illinois, the southern third of Iowa, the northwestern half of Missouri, the extreme eastern border of Nebraska, Kansas and Indian Territory, western Arkansas, and extends still farther southwestward in a narrow belt into central Texas. The Mississippi river divides the area into two parts: an eastern district, including about one-third of the entire basin, and a western portion embracing the remaining two-thirds. Along 1. the dividing line the great water-course has cut its channel completely through the coal strata, exposing in a narrow border on each side rocks much older. Everywhere within the limits of the area just bounded along the borders of the stream outliers or pockets of the coal-bearing layers are found in ancient gorges and depressions, the connecting beds, if they ever existed, having been almost completely removed through erosion, leaving only scattered remnants of their once greater extension. The 


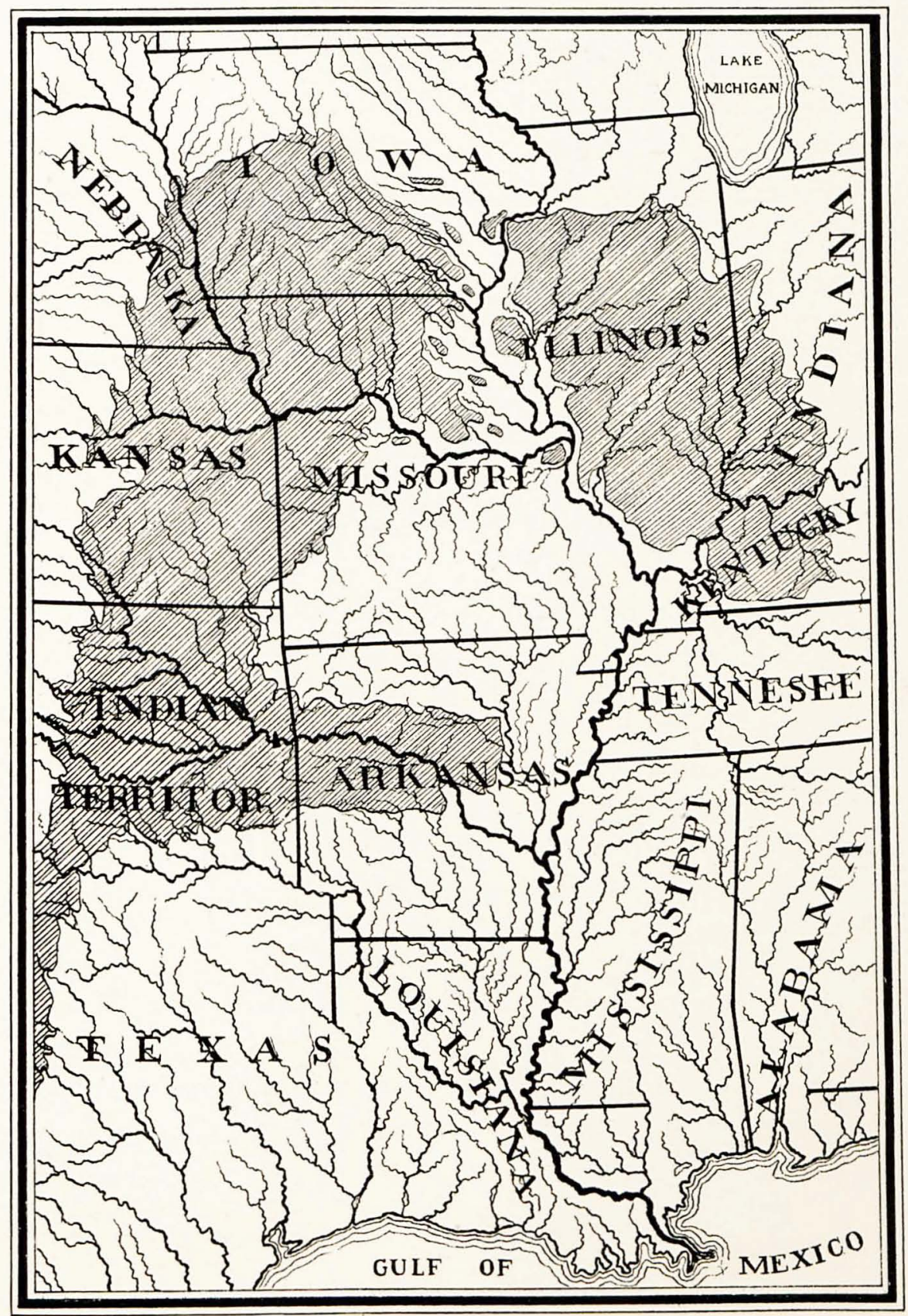

SKETCH-MAP OF THE INTERIOR COAL BASIN. 

strata reforred to cover a little over one-third of the entire surface of Iowa. Geometrically the area is a trapezium with the entire southern boundary of the State forming. one side; the Missouri river another; an irregularly curved line connecting Keokuk and Fort Dodge a third; while the fourth or northwesterly side is not as yet well defined on account of the deep deposits of drift materials covering the region, but it is probably approximately along a sinuous line rumning from Fort Dodge to Council Bluffs.

Beyond the boundaries mentioned, eastward especially, outliers of coal deposits are scattered even as far north as Jackson county, on the Mississippi river. Many of these isolated basins afford seams of coal sufficiently thick for profitable working.

The distribution of the coal-bearing rocks of the State, as briefly described above, is shown graphically in the accompanying sketch map. (Plate vi.) It will be noticed that the rocks having the same geological age as the coal of Iowa, and in which there is more or less likelihood of obtaining coal, are distributed over one-half of the total number of counties in the State. The area covered by these Carboniferous strata is not far from 20,000 square miles.

It must not be inferred, however, that the coal is equally distributed over all of this area, for such is not the case. The broad belt running southeast and northwest, and traversed its entire length by the Des Moines river from Fort Dodge to Keokuk, has heretofore been found to be much more productive of coal than other parts of the district. Lately in places outside of this belt coal has been discovered in abundance. Mines are rapidly being opened throughout this area, often where the presence of the commodity was unsuspected before.

6 G. Rep, 
Topography.-The surface of the Iowa coal region is topographically a gently undulating plain, moderately elevated, and tilted slightly southward. The larger watercourses traversing this district have cut their channels. rather rapidly to a moderate depth. On this account, in the vicinity of these streams the country is much morebroken than in the interior, and the slopes descend often quite abruptly.

The elevations of the places in the subjoined table show the altitudes above the sea-level of the different parts. of the plain:

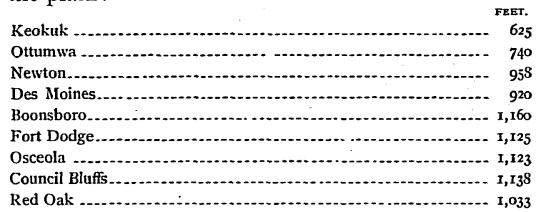

Where the larger streams cut the elevated plain the altitudes are from 150 to 200 feet lower than those of the general surface.

All of the coal region of Iowa lies within the limits of the glaciated area, and the entire surface is covered, consequently, with glacial débris, often to a considerable depth. The topography of the State is thus greatly subdued by the deposits of drift and loess.

Drainage.-The extreme eastern margin of the Iowa. coal district is watered by the two sluggish branches of the Skunk river. West of this basin the Des Moines, flowing southeasterly, drains more than one-third of the entirearea; while the southwestern part of the State is cut by numerous small tributaries of the Missouri river. 
Geological Subdivisions.-With the exception of a few carbonaceous seams in the Cretaceous rocks in the northwestern part of the State, the coal-bearing strata of Iowa belong to the median portion of the Carboniferous age, or Coal Measures. The rocks of this formation are made up largely of argillaceous materials, with sandstones and limestones, the coal beds forming an inconspicuous part of the entire series. It has been customary in Missouri and Iowa to subdivide the Coal Measures into:

(3) Upper Coal Measures.

(2) Middle Coal Measures.

(1) Lower Coal Measures.

The exact lines of demarkation have been very different in the various states within the limits of the interior coal field. In Iowa and Missouri, for instanee, the "lower" Coal Measures of the former do not correspond at all with the similarly named divisions represented in: the latter state. The same may be said in regard to the so-called middle and the upper Coal Measures of these twoprovinces. White, following the idea already suggested, also divided the Coal Measures of Iowa into Lower, Middle and Upper divisions, each of which he regarded about 200 feet in thickness. Recently it has been shown* that the respective thicknesses of the three formations already referred to are very different from the measurements ascribed to them by the author just mentioned. The vertical distance between the base and the top of the lower member is more than double the distance usually given, or over 400 feet. White's middle member is very much thinner than was at first supposed. From investigations lately made in both Iowa and Missouri, the actual thickness of the "upper" Coal Measures is found to be more than five

${ }^{\star}$ Keyes : Bul. Geol. Soc. America, Vol. II, pp. 277-292. Rochester, 189i. 
times the vertical distance formerly estimated, that is, more than 1,000 feet. Winslow, from special observations in northwestern Missouri, concludes that the "Upper" Coal Measures cannot be less than 2,000 feet in maximum thickness.

In considering the Coal Measures as a whole, two tolerably distinct classes of sediments are readily recognized : (1) the marginal or coastal deposits, and (2) the beds laid down in the more open sea.

These two categories are sharply contrasted lithologically, stratigraphically and faunally. The first is characterized by the rocks being predominantly clay-shales and sandstones, with practically no limestones. The individual beds have usually a very limited extent, and replace one another in rapid succession, both laterally and vertically. The sandstones often form great lenticular masses, sometimes deeply channeled on the upper surface, the excavations being filled with Coal Measure clays. These and many other phenomena attest a constantly shifting shoreline and shallow waters. The fossils contained are nearly all brackish water forms or shore species. Remains of pelagic organisms are not numerous.

On the other hand, the second class above mentioned is made up largely of calcareous shales, with heavy beds of limestone. The layers are evenly bedded, and extend over very considerable distances. The faunas are chiefly composed of strictly open sea forms.

As the conditions of deposition were evidently those of a slowly sinking shore, the marginal deposits as a whole practically underlie the open sea formations, the former being regarded as the Lower Coal Measures and the latter as the Upper Coal Measures. At the same time it must be remembered that this does not necessarily imply that the 
"lower" measures are to be considered much older than the "upper," but rather that along the great and successive planes of sedimentation different beds of the upper and lower divisions were laid down contemporaneously.

Vhile the general divisions of the Coal Measures may be readily recognized, it does not seem advisable to draw an exact line of demarkation between the two formations until the evidence of the faunal studies already begun has been fully taken into consideration and a comparison of the results of the different methods of solving the problem is made.

With this idea of the Coal Measures of the interior basin, the limits of the two formations in Iowa assume somewhat different lines of separation from those which have been commonly recognized.

It is proposed, therefore, to divide the "Upper" Carboniferous, or Pennsylvanian series, into:

(2) The Missouri Stage.

(1) The Des Moines Stage.

The Des Moines formation represents the lower Coal Measures, or the marginal deposits of the upper Carboniferous. It takes its name from the Des Moines river, which flows for more than 200 miles directly through the beds of this terrane. It extends into Missouri, and follows the northern and western boundaries of the Ozark uplift into Kansas and Indian Territory.

The Missouri terrane corresponds essentially with the "upper" Coal Measures, representing the more strictly marine beds. It is the formation typically developed in the northwestern part of the state of Missouri. The Missouri river also winds its way for more than 400 miles through the beds of this stage, exposing numberless fine sections on both sides of the stream throughout the entire distance. • 
DES MOINES BEDS, OR LOWER COAL MEASURES.

\section{Lithology of the Lower Coal Measures.}

In order of their abundance the rocks of the Iowa Coal Measures are clay-shales, sandstones, limestones and coals. The secondary part that the calcareous beds play in the upper Carboniferous of the State, especially in the lower divisions, sharply distinguishes the formation from the other Paleozoic rocks. Below, the Coal Measures rest on a great basement of massive limestones, with but few clay or sand beds of separation. Not less striking is the relative thinness, as a rule, of the individual layers which follow and replace one another, upwards and laterally, in rapid succession. Often within a vertical distance of a few inches or a few feet, layers of clay, sand or shale are succeeded by different strata, or else are changed both in color and chemical composition.

If the upper and lower divisions of the Coal Measures in Iowa were to be contrasted upon a single lithological character, it would be found that the former is prevailingly calcareous; the latter prevailingly argillaceous. Further comparing, the upper measures have even their clay-shales charged with disseminated lime; the lower measures have their limestone beds commonly in thin. bands, few in number. The sand beds in the superior portion of the upper Carboniferous are usually shaley, mixed with much calcareous and clayey material; in the inferior part the arenaceous formations are often great sandstones, frequently of very considerable geographic and vertical extent. As regards carbonaceous materials, there is a very great predominance in the "lower" Coal Measures-not only disseminated through the elays, making them often highly bituminous, but concentrated 
in very pure seams and beds, furnishing by far the greater part of the coal mined in the State. The "upper" Coal Measures, though carrying some workable coal, are meagerly supplied with bituminous matter as compared with the formation immediately underlying them.

The two subdivisions of the Upper Carboniferous being so well distinguished in a general way by their differences in constructional materials as well as in other ways, it would seem desirable to treat more especially and in detail the lithological features of the Lower and Upper members separately.

Clay-Shales.-As already intimated, these materials make up by far the greater part of the formation as represented in Iowa. On exposure to atmospheric agencies they quickly disintegrate into soft clays and are easily carried away by running water. For the most part they are ashen, drab, or black in color, though red, yellow, buff and blue shades are of not uncommon occurrence. In some localities the variegated shales-blue, red, drab, yellow and ashen indiscriminately mingled-predominate.

The shales may be (1) argillaceous, (2) arenaceous, (3) calcareous, or (4) bituminous. Those of the first category are usually rather light colored, massive and hard. By the gradual addition of fine sandy material on the one hand they pass imperceptibly into sandy shales; these again into shaley sandstones, and finally into hard, compact sandrock. On the other hand, through the increase of lime constituents these deposits grade into calcareous shales, then to earthy limestone, and finally to ordinary limerock. In another direction carbonaceous matter may rapidly become prominent; the shales acquire a dark color, assume a highly bituminous character and finally pass into coaly layers. These gradual transitions may 
take place laterally in the same horizon, or vertically from one layer to another.

In many places in the light colored clays crystallized gypsum occurs abundantly. At Des Moines, for instance, where diamond-shaped crystals of selenite are the more plentiful, it is not an infrequent occurrence to find individuals greatly elongated in the direction of the vertical axis, sometimes to a length of eight or ten inches. In the latter twinning is quite common. Often the crystals are acicular and, radiating from a center, form little rosettes, which lie in great numbers on the exposed surface of clays. Occasionally the light colored shales also afford impressions of ferns and lepidodendron roots, but for the most part they are unfossiliferous. The dark colored bituminous varieties, on the other hand, are often highly charged with organic remains. For a single locality nearly one hundred species of invertebrates have been recognized, besides a number of fossil fishes and plant remains.

Sandstones.-Although a large amount of sandy material is present in the Coal Measures of the region under consideration, it is usually mixed with clay to such an extent as to actually form sandy shales. In some cases, however, the sand constitutes a rock which is sufficiently compact to afford material for ordinary rough masonry. The hard portions of the sandstones are for the most part very limited, being only two or three feet in thickness; or in the form of large spherical concretions in a softer matrix. These sometimes attain a diametric measurement of five or six feet. Within the limits of the area in question there are some notable exceptions to the general character of the arenaceous deposits; as for example, the "Redrock" sandstone. This sandstone has long attracted popular atten- 
tion. The bright vermillion cliffs rise to a height of one hundred to one hundred and fifty feet above the water surface of the Des Moines river. The red coloration of the rock is, however, local, merging laterally and downward into a yellow or buff color. At Redrock Cliff the stone is, for the most part, massive; but rather soft and thin-bedded above. At this place it is a very fine-grained and homogeneous sandrock, some portions even affording excellent material for grindstones. But southwestward, and at Elk Bluff, two miles below, the sandstone passes into a finegrained, ferrugineous conglomerate. Occasionally large spherical concretions are met with. In the upper part it becomes thinly bedded, with a considerable amount of clay intermingled. The base is rich in plant remains; lepidodendrids, sigillarids, calamites, and ferns of many species. The upper surface has been subjected to sub-rerial erosive agencies, as has been fully shown in another place.* The : formation is, then, an enormous consolidated sand-bed, having a geographic extent of more than twenty miles in one direction, and at least six or seven miles in the other, with a maximum thickness not less than 140 feet.

The sandstone of Redrock has recently come into prominence as a building stone; and is now used more or less extensively throughout the State for the better class of architectural work. Long ago this rock was utilized in various structures at Des Moines and elsewhere, but the method of obtaining it by blasting shattered the stone so as to render it almost worthless for building purposes. It soon fell into disrepute, and for more than thirty years has not been used, except for unimportant local masonry. Recently extensive steam sawing apparatus has been brought in, the stone being removed in huge blocks and

*Am. Jour. Sci., (3), Vol. Xl.I, pp. 273-276. 1S9s. 
reduced by further sawing to sizes required. In this way the sandstone is not injured as when the blasting method was in vogue. The resistance to crushing power of the better portions of the rock is now considered to be nearly equal to any in the country.

Of the other compact sandrocks of the Iowa Coal Measures, the most important, perhaps, is what is known as the "basal sandstone." Instead of being a single bed, as might be inferred from the name, it is, in fact, made up of a number of isolated masses. The name, however, is still very appropriate, as the rocks under consideration are usually found at the base of the Coal Measure series, filling depressions and old gorges eroded in the underlying lime-

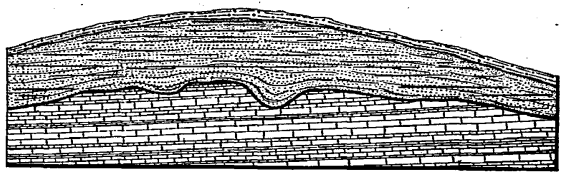

Figure 4. Relations of Coal Measure sandstone and Saint Louis limestone, Ft. Dodge.

stones prior to the laying down of the Upper Carboniferous. Figure 4 . The basal sandstones are more conspicuous, perhaps, in the outliers of Carboniferous strata where the superincumbent beds have been removed through erosion. At Keokuk, in Lee county, sandrocks of the character just described form the upper part of the bluffs along the Mississippi and Des Moines rivers. They have a thickness of twenty-five feet or more, and are durable enough in places to furnish material for ordinary masonry. Plate ix shows the contact of the Coal Measures sandstone and the Saint Louis at Keokuk. The arenaceous beds commonly rest directly upon the Saint Louis limestone, the upper surface 
of which is seen in many places to be deeply eroded and uneven. The sandstone at the bottom is very unevenly cross-bedded, indicating the shallowness of the waters in which it was deposited. Similar massive sandstones have long been quarried at Muscatine, where certain parts of the beds have hard concretionary masses of spherical shape, very much like as in the Redrock occurrences. Other exposures of Carboniferous sandstones are found

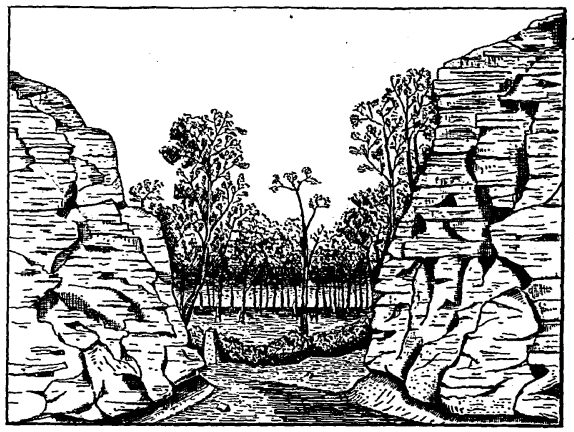

Figure 5. Bluffs capped by Coal Measure sandstone. Des Moines.

along the Iowa river. Figure 5 shows a section of the sandstone near Des Moines, on the river of the same name. As the whole, however, the sands of the Lower Coal Measùres are distributed largely as sandy shales.

The organic remains found in the sandstones and the more compact of the sandy shales are almost entirely plants. Beautiful ferns are not uncommon. Many kinds of Lepidodendron and Sigillaria are very abundant, as well as huge Calamites. In certain parts of the Redrock sand- 
stone, south of Pella, Marion county, for example, it is not unusual to see tons of great.plant trunks, finely marked, lying in the talus at the foot of the mural escarpments along the Des Moines river. Other localities are equally prolific of vegetable remains.

Calcareous Beds.-The limestones of the Lower Coal Measures play an unimportant part in the lithological features of the region. They consist merely of a few thin bands, chiefly in the upper portion of the section, above the Lower Coal Measures as commonly designated in this State. Though seldom exceeding ten or twelve inches in thickness, these calcareous bands are the most persistent and easily recognizable, over wide areas, of any of the horizons in central Iowa. They are fragmentary or nodular, very impure from a large admixture of clayey material, and more or less highly fossiliferous.

Coals.-Little need be said here concerning the lithological characters of the coals of the State. They are all of bituminous varieties, though a few limited deposits of tolerably good cannel coal are known. The seams vary from a few inches to seven or eight and even ten feet in thickness, the average of the veins at present worked being between four and five feet. These beds are disposed, not in two or three continuous layers over the entire area, as has been commonly supposed, but in numerous lenticular masses from a few hundred yards to several miles in extent. As a rule, the coals of the State are rather soft, and often contain some pyrites, besides frequently small flakes of lime or gypsum along the lines of stratification and fracture. Thin shaley seams also occur. Almost without exception the workable coal beds are underlaid by a soft white clay, which is often taken out along with the coal and made into fire brick. The "fire-clay" has a 
thickness from a few inches to several feet. Usually, roots of lepidodendrons are found abundantly in the under clay. The roof of the coal beds is usually a bituminous fissile shale, intensely black below, but commonly getting lighter colored upwards. The thickness of the "roof" may vary from a few inches to fifteen or twenty feet. For the most part the black shales are highly fossiliferous. There is present, also, more or less pyrites in irregular rounded nodules or in sharply bounded crystals. Frequently just above the coal, in the lowermost layers of the roof, there is a black, nodular band of hard, calcareous material, the individual spherical masses being called, locally, "nigger-heads." These attain a measurement from one to ten feet across. They are charged with fossils, chiefly lamellibranchs and gasteropods of great variety. The "nigger-heads" are quite distinct from the septarial masses often associated with the coal and having the same general appearance.

Associated with the coal beds in many places are darkbrown layers of compact massive rock, having a metallic ring when struck with a hammer. It is one of the ores of iron. At Flagler, in Marion county ${ }^{r}$, one bed ten inches thick separates a five-foot vein of coal into two parts.

- Stratigraply of the Lower Coal Measures.

General Remarks.-Like the lithological characters, the stratigraphy of the Iowa Coal Measures presents in a genoral way two rather well marked phases, the one distinctive of the lower division and the other of the upper portion. of the coal series. Inasmuch as the first named division represents marginal sediments, and the second open sea deposits, each may be very appropriately considered separately. 
The Coal Measures of central Iowa, in Marion, Polk and Dallas counties, are perhaps better understood geologically than in any other part of the State. Both the structure and arrangement of the coal-bearing strata have already received considerable attention. The phenomena presented may be taken as typical of a greater part of the Iowa coal field.

Quite recently a very detailed section was made from Harvey, in the southwestern part of Marion county, along the line of the Des Moines river to the capital city, and thence up the Raccoon river to De Soto, in Dallas county, a distance of sixty-five miles. The circumstances of its construction have been made very favorable by the numerous excellent exposures afforded by railway lines that have been built nearly the entire distance on each side of the two streams. These railway cuts, taken together with the natural outcrops on the rivers, permit the stratigraphy of the district to be very satisfactorily traced in all the minor particulars.

Along the line just specified, more than two hundred exposures were examined and measured, the different beds being carefully correlated in the field by direct passage from point to point. Out of this number, ten of the most instructive and typical sections have been selected, and descriptive notes indicating the salient characters of the various strata appended. Each is marked on the accompanying general section, the base of which is the low-water limit in the Des Moines river. It is thought that the two methods of illustration will adequately present, in the briefest.possible manner, the leading geological features of the region. The stratigraphical relations of the several beds will find further explanation beyond. 


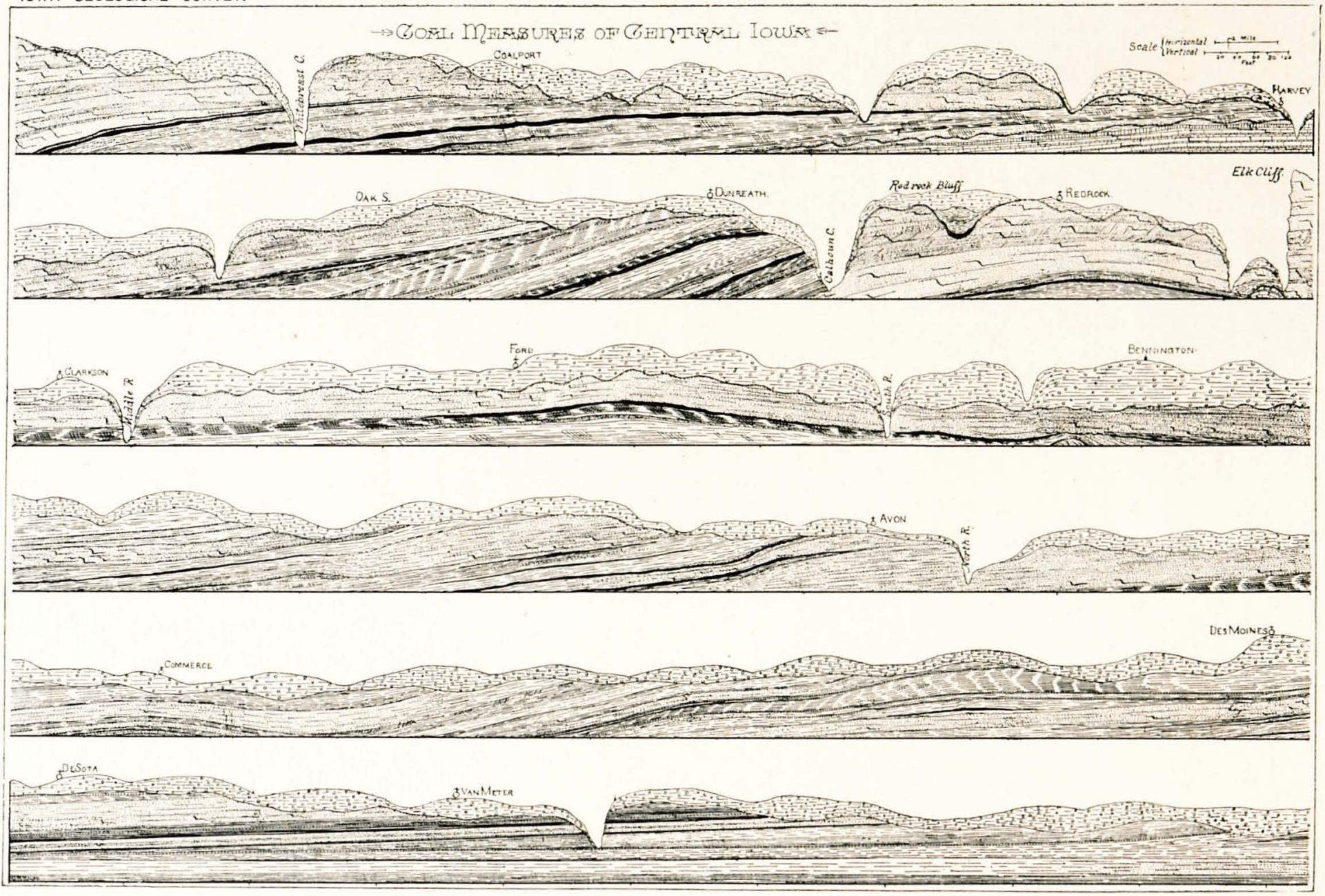

GEOLOGICAL SECTION ALONG DES MOINES AND RACCOON RIVERS IN CENTRAL IOWA. 

The Quaternary deposits have not yet been differentiated with sufficient care to warrant the separation, in a general section, of the drift sheets and the loess.

DETAILED DESGRIPTION OF A ONOSS-SECTION IN CENTRAL IOWA.

I. Harvey Exposure.-Quarry in S. W. qr. N. W. qr. Sec. 4r T. $75 \mathrm{~N}$., R. $7 S \mathrm{~W}$.

FEET.

3. Drift and loess (exposed)

10

2. Gray and ash-colored marl, with abundant fossils: Spirifera keokuk Hall, Pentremiles koninckiana Hall, Zaphrentis spinulifera Hall, Athyris subquadrala Hall, Productus marginocinctus Prout, and others.

x. Blue limestone, weathering brown in places, thinly bedded above (exposed)

II. Coalport Section.-S. E. qr. S. IV. qr. Sec. 4, T. 76 N.r. R. $19 \mathrm{~W}$.

6. Heavily bedded sandstone, with lepidodendrids, sigillarids, filices and calamites below (exposed)

5. Dark colored clays and shales, sandy in places................. 30

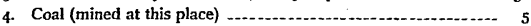

3. Dark clays and bituminous shales ............................. 14

2. Coal, rather impure

I. Sandstone, very thinly bedded, and sandy shales (exposed to

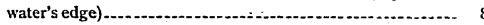

No. 6 of this section is not exposed on the river bluff at this place, but crops. out in a ravine some distance inland.

\section{Redrock Exposures (Plate VIII).}

12. -Drift and loess, with characteristic fossils

11. Drab and yellow, clayey shales.............................

ro. Coal (small basin only)

9. Fire-clay, enclosing rounded, water-worn pebbles, up to one foot in diameter, of "Redrock" sandstone, most abundant on the sloping sides of an ancient ravine.

8. "Redrock" sandstone; a fine-grained, massive, yellow and red sandrock, concretionary in places, the upper surface more or less weathered and channeled; maximum thickness more than I5o feet (exposed) ....................................... 55

7. Shale, laminated and highly bituminous ..................... 2

6. Yellow sandstone, soft, fine-grained and thinly bedded ......... 3 ....

5. White sandrock, compact..................................... 
4. Yellow sandstone (like No. 6)

FEET.

3. Highly bituminous shales, laminated and coaly above anỏ becoming more and more coal-like westward

hite sandstone, fine-grained, everywhere penetrated vertically by rootlets of lepidodendrids ....... ................ 2 to 4

I. Shales, ash-colored and yellow (exposed to water's edge)....... 20

Numbers 12 to 8 are shown in a quarry at Redrock bluff, in N. W. qqr. N. E. qr. Sec. 35, T. 77 N., R. 20 W., and are represented in figure 1 , plate X. The rest of the section is exposed on the opposite side of the Des Moines river, in S. IV. qr. Sec. I, T. 76 N., R. 20 IV.

IY. Dunreath Exposures.-N. E. qr. Sec. 2S, T. 77 N., R. $20 \mathrm{~W}$.

15. Quaternary deposits

14. Clayey and sandy shales (exposed)

13. Dark clayey slate, with abundant ferns at base ................. 10

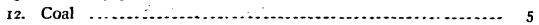

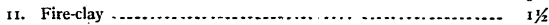

10. Clayey and sandy shales .............................. 45

9. Sandstone, massive and compact, in two layers, separated by a soft, sandy seam and a thin bituminous bed, with abundant calamites and a few lepidodendrids...................... 5

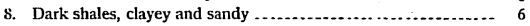

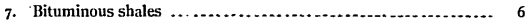

6. Coal, impure in places

5. White fire-clay ................................... 4

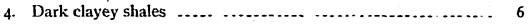

3. Thinly bedded clayey sandstone, with numerous lens-shaped septarial concretions up to four feet in diameter............ 7

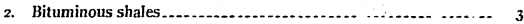

1. Dark colored sandy and clayey shales (exposed) ............ 45

V. Bennington Section.-S. E. qr. N. W. qr. Sec. 9, T. 77 R. $27 \mathrm{~W}$.

7. Loess and stratified drift................................ 47

6. Yellow sandstone, thinly bedded.......................... 20

5. Blue sandstone, with a layer of white clay

4. Bituminous shale, with a compact, nodular and highly ferruginous

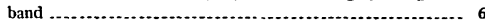

3. Coal ...... . .

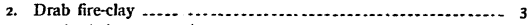

1. Sandy shales (exposed) ........................................ 5 
VI. Ford Bluff.-N. E. qr. S. E. qr. Sec. 10, T. 77 N., R. $22 \mathrm{~W}$.

9. Dift and loess

8. Light yellow sandstone, soft, heavily bedded above, thinly bedded below, with much clay............................................ 35

7. Dark shale, highly bituminous in places, with hard concretionary

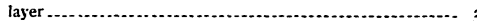

6. Fire-clay, with sigillarid roots............................... $1 / 4$

5. Drab shales, somewhat sandy above........................... 12

4. White clay ............................................. 3

3. Soft sandstone, buff, heavily bedded........................... 4

2. IVhite clay ..................................................... 4

I. Sandy and clayey shales (exposed to water-level) ............... 25

VII. Des Moines Section.-(Several Exposures in the City of Des Moines.)

17. Variegated clayey shales

16. Blue, earthy limestone, nodular and weathering brown; contains Productus muricatus N. and P.; Choneles vernenilianus N. and P., Streptorhynchus crenistriatum Phillips

Variegated, clayey shales.....................................

15. Bituminous shales, with concretionary masses below which contain Productus muricatus N. and P., P. cora, d'Orb., etc. A thin coaly seam shown in some places ........................... 3

13. Light colored, clayey shales, drab and yellow................. 7

12. Variegated clay-shales............................................ 4

I I. Nodular limestone, earthy throughout, highly fossiliferous ...... $1 / 2$

Io. Light colored and variegated shales............................ 5

9. Impure limestone, somewhat fossiliferous...................... I

8. Light colored clays ........................................ 5

7. Buff colored, micaceous sandstone, concretionary in places and passing into sandy shales elsewhere ....................... 15 to 25

6. Light colored shales, sandy in places ......................... 4

5. Coal, impure.................................................. 2

4. Light and dark sandy shales ...................................... 20

3. Bituminous shales, highly fossiliferous .......................... 2

2. Coal, rather impure .......................................... 2

1. Fire-clay (exposed to water level)............................ I

VIII. Commerce Exposure.-S. E. qr. N. W. qr. Sec. 29, T. 78 N., R. $25 \mathrm{~W}$.

6. Drif

5. Clay shales, passing into sandy shales........................ 20

4. Buff sandstone, soft, thinly bedded ........................... 15 
3. Variegated clays

2. Blue limestone, in three layers, separated by partings of marl... $21 / 2$

I. White shales (exposed to water level)

IX. Van Mfeter Bluff.-S. W. qr. N. E. qr. Sec. 26, T. $78 N^{r}$, R. $27 \mathrm{~W}$.

14. Drift

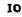

13. Light colored shales, clayey

12. Compact, fossiliferous limestone

II. Fissile, bituminous shales, coaly below..................... $11 / 2$

10. Light colored clay-shales

9. Brown sandstone, heavily bedded, and containing abundant roots of lepidodendrids and fronds of ferns

8. Clayey shale, sandy above

7. Coal

6. Variegated clays and shales

5. Bituminous shales

4. Fragmentary limestone.

3. Blue and gray shales

2. Bituminous shales, with concretionary layer above

I. Blue, clayey shales (exposed)

X. De Soto Section.-N. W. qr. S. W. qr. Sec. 30, T.78 N., R. $27 \mathrm{~W}$.
14. Drift
13. Gray limestone, fossiliferous .............................. $x$
12. Variegated clay-shales....................................... 8
II. Buff sandstone, soft, thinly bedded and shaley ................. 30
10. Blue, clayey shale............................................... 5
9. Limestone, compact, fossiliferous............................. 2
8. Highly bituminous shales, coaly below, with several clay partings 4
7. Shaley sandstone, with highly ferruginous band above......... $2 \frac{1}{2}$
6. Sandstone, compact......................................... 3

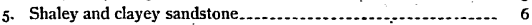

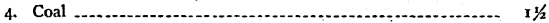
3. Fire-clay -............................................... 4
2. Fragmentary limestone, fossiliferous........................... 2

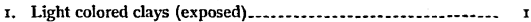

Passing westward from Harvey at the southern extremity of the section, the Saint Louis limestone, overlaid at frequent intervals by white, fossiliferous marls from a few inches to fifteen or twenty feet in thickness, disappears below the level of the water in the Des Moines 
river, at the bridge spanning the stream on the Pella and Knoxville road. This limerock appears again at Elk cliff, just below the town of Redrock, in a low anticline exposed for a few hundred yards. At various places this limestone shows its upper surface channeled and unevenly eroded, the soft, white clays which form the superior member of the formation in the district being completely removed. Coal Measure clays or sand fill these ancient ravines. The extent of the erosive action that took place prior to the deposition of the Coal Measures has not as yet been accurately made out. In a distance of ten miles, between Harvey and Elk cliff, where careful and satisfactory measurements have been taken, it is known that not less than seventy-five feet of shales intervene between the two horizons of the lower Coal Measure sediments in contact with the Saint Louis limestone of the two places.

The exposure at Elk cliff is very instructive for other reasons than those already mentioned. A small but deep ravine divides the section. On the left is the Concretionary limestone - the last outcrop of the Saint Louis in central Iowa to be noted in the ascent of the Des Moines river. At this place it rises, in a low arch, about fifteen feet above low-water. Overlying it are marly and somewhat sandy shales, which have a vertical exposure of sixteen feet. The Redrock sandstone rises in vertical cliffs to a height of 150 feet. The inclination is $5^{\circ}$ to the westward; but the dip is perhaps even greater to the southward. The strata are visible down to the water's edge. The direct line of contact between the arenaceous and calcareous beds is not shown, as the detritus brought down by the streamlet and the alluvial material deposited at its mouth by the Des Moines during high water completely conceal the stratified rocks for several yards on each side 
of the entrance. In his ascent of the Des Moines riyer in 1852, Owen observed the same exposure and thought that it indicated a fault of 150 feet or more. It is probable, however, that the case is one similar to that exhibited at the Redrock quarry; and that the limestone area at the time of deposition of the sandy material was a slowly sinking island or low promontory; which was eventually completely covered by the arenaceous deposits.

At the bottom of the Redrock bluff the fine-grained sandstone is very homogeneous, and rarely shows bedding planes. Toward the top, however; the sandrock becomes thinly bedded. Very different are the lithological characters of the stratum as exposed at Elk cliff, a couple of miles away, where a fine-grained; ferruginous conglomerate takes the place of the sandstone. The dip is everywhere to the south and west; and a short distance above the quarry just alluded to; the inclination is very considerable. A mile beyond, the sandstone has disappeared completely and the section shows only shales and clays. The space between the latter exposure and the last known outcrop of the sandstone is perhaps half a mile, the interval being hidden by Quaternary deposits down to the water-level. The abrupt change in the lithological characters of the rocks in so short a distance has been mentioned by Owen* and Worthen, $\dagger$ but the true explanation is entirely different from the suppositions of those writers.

The strata overlying the sandstones as disclosed in the Redrock quarry are shown in the accompanying figure. (Plate viii, fig. 1.) The upper limit of the sandstone is very uneven and paved everywhere with rounded, waterworn boulders and pebbles, derived from the sandstone

*Geol. Rep. Minn, Iowa and Wis. 1852 .

†Geol. Iowa. 1858 . 


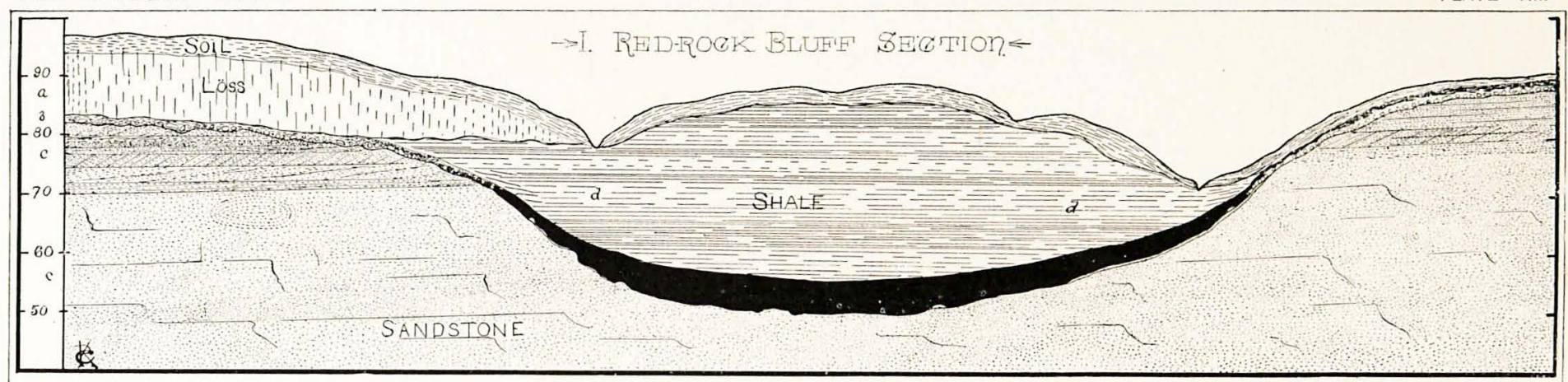

$\rightarrow$ II. REDFOCK EXXPOSURE
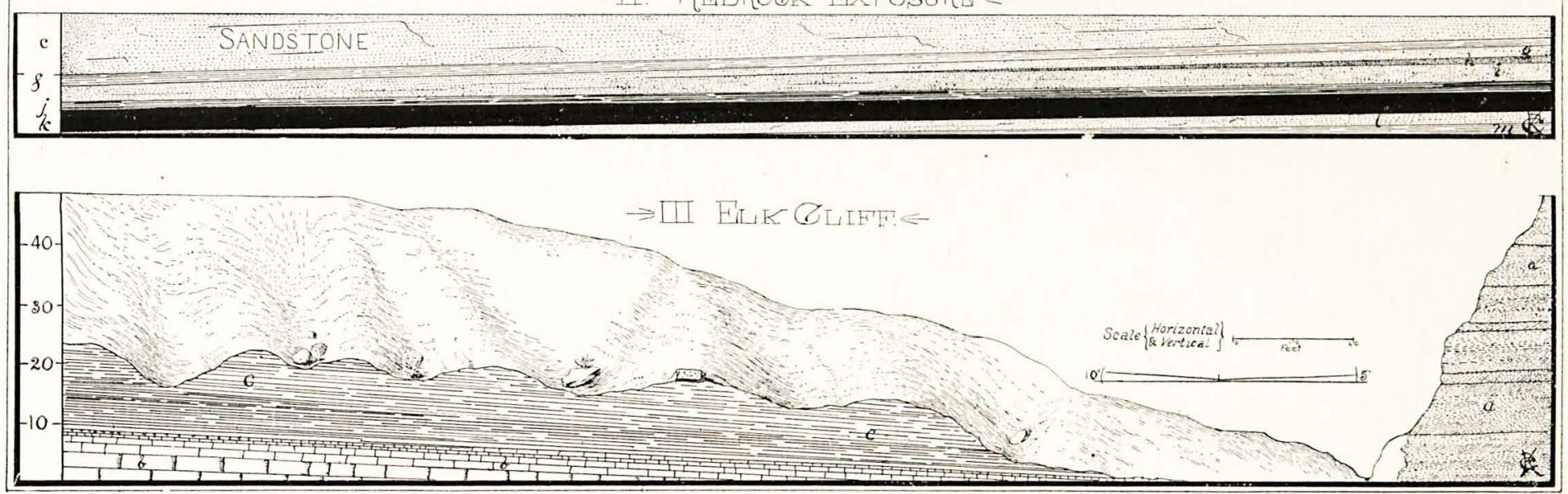

UPPER AND LOWER LIMITS OF THE REDROCK SANDSTONE. 

itself. A fire-clay covers this pavement; and upon it rests a coal bed having a thickness of six feet centrally, but rapidly thinning out laterally in both directions to a very unimportant, scarcely recognizable, bituminous seam. Northward, or at right angles to the face of the section, the coal is thicker. Superimposed upon the coal are drab and ash-colored, clayey shales having an exposed thickness of thirty feet, but they are manifestly much more extensive. From a consideration of this section, then, it is clear that before the superimposed coal seam was formed the vast sand-bed had been raised above the surface of the waters, consolidated, and then subjected to considerable denundation. In a small gorge or ravine, excavated in the sandstone, the carbonaceous material was deposited as the land was again being submerged. Immediately to the north of the section represented in the figure (which faces the south) the corrasion was much more vigorous, as is shown by the rapid inclination of the axis of the gorge in that direction; so that the section is actually across a tributary ravine opening into a large basin in which the coal is now mined in large quantities. The inference is, then, that the abrupt disappearance of the great bed of sandstone in such a short distance as half a mile above the quarry where it has an exposure of more than one hundred feet, is not due wholly to the inclination of the stratum, but it is the result of great erosion in that direction, previous to the deposition of the shales and clays; and that the massive sandstone really formed a bare hill of considerable height against which the subsequent deposits were laid, when the conditions favorable to such a change occurred.

Here, to all appearances, is an extensive sandstone formation with a maximum thickness of more than one 
hundred and fifty feet, lying unconformably upon the Saint Louis limestone and with coal-bearing strata imposed unconformably upon it. At one time it was thought the sandy member represented shore or estuary deposits of the Kaskaskia sea. Such, however, was found not to be the case. A few miles below Elk eliff, as already remarked; exposures were observed showing fully seventyfive feet of dark, sandy, clayey and bituminous shales betwreen the sandstone and the Concretionary limestone. The shales carry at least two workable seams of good coal, one of which attains a thickness of five to seven feet and has a very considerable geographical extent.

The recent observations, therefore, have cleared up many of the hitherto doubtful points concerning the geological history of the Redrock sandstone. It is not the basal member of the Coal Measures, as was regarded by Worthen; nor is it a shore extension of the Kaskaskia limestone; neither is its geographical extent as limited: as has been supposed. Twenty miles to the southeast of Redrock a sandstone of great thickness, having identical lithological characters and with a similar stratigraphical position, is believed to be its extension southward. It may also rise a few feet above low-water in the northwest corner of Marion county. The most interesting consideration in regard to the Redrock sandstone is the fact of its considerable elevation above the surface of the sea and its subjection to sub-ærial erosive agencies for a long period of time before submergence again took place. During the interval the great thickness of sandstone probably was almost entirely removed in places.

A short distance above the Redrock eliff the great sandstone disappears completely, not on account of rapid dips or faulting, but through erosion, which took place 
during Carboniferous times-the same agencies which were at work making the gorges in which coals and shales were laid down. The latter are inclined towards the west, forming part of a shallow syncline, as seen along the river: Eight miles above, near the old village of Bennington, the strata have already begun to rise considerably. At this place a very instructive section is exposed along the river bank. A small portion is shown in the subjoined figure. (Figure 6.)

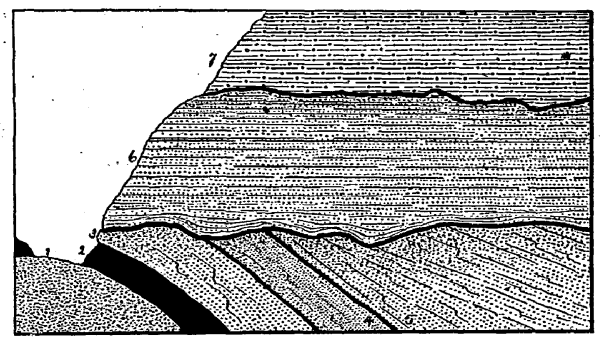

Figure 6. Section near Bennington, Marion County.

The succession of beds at Bennington is as follows :

7. Drift, with stratified layers of gravel and sand, and containing numerous boulders up to three feet in diameter.............. 40

6. Shaley sandstone, containing much clay, irregularly bedded below to

5. Buff sandstone, somewhat shaley in places.................... I5

4. Soft, blue sandstone............... 3

3. Buff sandstone, heavily bedded .............................. 4

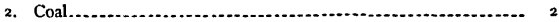

1. Massive sandstone, buff, rather compact (exposed)............. ro

In this section number 1 , the massive, compact sandstone, is somewhat concretionary in places. It appears to be a small knoll, rising scarcely ten feet above the water- 
level of the river and is exposed horizontally only for a dozen yards. Its rounded surface is considerably hardened and more or less ferruginous. In lithological characters this rock is identical in all respects with the Redrock sandstone and may represent the summit of an eroded elevation of that great sand stratum. Immediately overlying the sandstone and inclined at a considerable angle is a bed of coal two feet in thickness (number 2). Above the coal is a heavily bedded, yellow sandstone (number 3) having a measurement of four feet. This is followed by a soft, blue sandrock about three feet in thickness. The buff, rather soft sandstone, which follows, is heavily bedded at first but gradually becomes more and more thinly bedded eastward. The layers are inclined at first about the same as the coal bed, but in passing down the stream the dip acquires a lower and lower angle until a quarter of a mile away the planes of stratification are nearly horizontal. Below number 6 is a thin, ferruginous band about two inches in thickness, very irregular and cutting across the underlying beds obliquely. It marks a very uneven surface. Above it are ten feet of thin, clayey sandstone layers and sandy shales, the bedding planes following the sinuosities of the irregular band at first, but quickly assuming a straight, horizontal position. The sandy shales were evidently more extensive, but were probably removed largely through glacial action. More than forty feet of drift cover them.

From Bennington to Des Moines the strata are greatly undulatory, sometimes rising, sometimes sinking. Beyond Des Moines, westward, the layers become nearly horizontal, with very little or no change in the dip. This very noticeable difference in the laying down of the beds marks the passage from the "Lower" to the "Upper" 


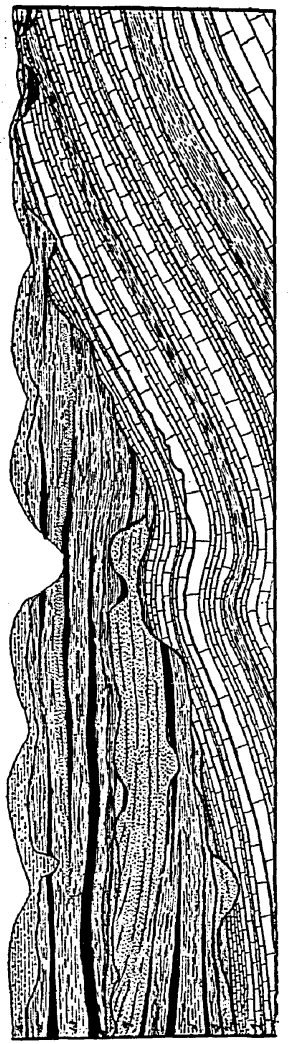

Coal Measures-a transition from the marginal or costal sediments to the more open sea deposits.

The geological crosssection of the Carboniferous in central Iowa, as described in detail in the foregoing pages, may be taken as representative of the Lower Coal Measures of the State. Further specific references are hardly necessary, as they will be fully considered in another place.

A summary of facts. brought out in the preceding pages may be graphically given in a generalized, or rather composite, section, as shown in figure 7 .

Briefly stated, these facts may be enumerated as follows:

(1) The Coal Measures of Iowa were laid down over an ancient surface with hills and vales, ridges and gorges. The line of overlap passing over Lower Carboniferous, Devonian, and even Silurian rocks. 
(2) The unconformity of the Lower Coal Measures of Iowa upon limestones of the Lower Carboniferous is much more pronounced than heretofore suspected The confirmation of this statement is found in excavations recently made at Elk cliff, at Harvey, at Fairfield; in Jefferson county, and elsewhere.

(3) The striking unconformities in the Lower Coal Measures have never been so apparent as at present. The most remarkable instance of this sort is the case of the Redrock sandstone. The thick sand bed had been manifestly consolidated, and elevated above the surface of the sea for a considerable distance; then it was subjected to long denundation, as is shown in the deep gorges and ravines which are still preserved in the hard sandstone. So wide-spread was the action of the erosive agencies that the great sandstone, more than one hundred and fifty feet in thickness, was largely removed; and at the present day only a few isolated outliers tell of its former great extent. When regional submergence again set in, the old gorges and shore depressions were occupied by small swamps.

(4) The earliest formed coal seams are far more extensive, both geographically and vertically, than the later ones. On the whole, the coal of Iowa may be regarded as distributed in innumerable lenticular basins, sometimes several miles in diameter and six or seven feet in thickness centrally, sometimes only a few hundred yards in extent. These occur at many different horizons and interlock with one another, so that a boring may pass through a score or more coal horizons without meeting more than one or two veins of sufficient thickness for profitable working. 
Variability of Strata.-Before finishing the consideration of the stratigraphical features of the Lower Coal Measures the conclusion will probably be arrived at that the beds present great variability. Such is indeed the case. In fact, it is one of the most striking characteristics of the formation as represented in Iowa. The rapid passage from one bed to another lithologically very distinct is everywhere apparent, the transition taking place vertically in different layers or laterally in the same horizon. But the different stages and the manner of gradation of the various beds from one to another have already been described sufficiently.

The Unconformity Between the Coal Measures and Saint Louis Limestone in Iowa.

As early as 1857, in a paper published in the American Journal of Science, James Hall wrote: "I have ascertained in the most satisfactory manner that the coal fields of Iowa, Missouri and Illinois rest unconformably upon the strata beneath, whether these strata be Carboniferous limestones, Devonian, Upper Silurian or Lower Silurian rocks."* Although no details were given, nor any references to the evidence made, this appears to be the first notice calling attention to the existence of a physical break in the Carboniferous rocks of the Mississippi basin.

A decade later, White, $\uparrow$ calling attention to the same fact, stated that another unconformity existed between the Saint Louis limestone and the underlying rocks of the Lower Carboniferous. These remarks also appeared subsequently in the Iowa report.t They are all very general in their character. But, there is added to Hall's observa-

*Am. Jour. Sci., (2), Vol. XXVII, p. 197. New Haven, 1857.

†Am. Jour. Sci., (2), Vol. XLV, pp. 331-334. New Haven, 1868.

†Geology Iowa, Vol. I, pp. 225-229. Des Moines, iS7o. 
tion the important fact that the Saint Louis limestone also overlaps in the State of Iowa. The nature of the physical break in question as exhibited in the upper Mississippi basin is fully considerred elsewhere in connection with the paragraphs on the oscillation of the Carboniferous shore-line.

In Iowa, at least, it appears that the extension of the Coal Measures beyond the boundaries of the Saint Louis limestone was much more than an overlap in the ordinary sense of the word, such as might have taken place off shore in gradually deepening waters. It was a sinking of an ancient land surface that had been more or less profoundly carved into hills and valleys, affording protected nooks favorable to swamp formation and the rapid accumulation of vegetable materials.

In mining operations, especially east of the Des Moines river, the importance of these facts, concerning both the disposition of the coal beds towards the base of the series and the true nature of the bottom of the Coal Measures, can hardly be over-estimated. Instead of a perfectly flat plane as commonly supposed, the surface upon which the coal deposits were laid down was topographically not very unlike the present surface features, though of course there is no coincidence of hills and valleys, for an ancient elevation often is exposed in one of the modern river beds.

Unconformities in the Coal Neasures.-Local unconformities in the Iowa Coal Measures are well shown in a number of places. The one noticed in connection with the Redrock sandstone, already described in the geological cross-section of the Coal Measures in central Iowa, is - perhaps the most prominent now known. It is fully 200 feet above the Lower Carboniferous limestone. Sections show an entire thickness of more 
than 100 feet of the Redrock sandstone to be removed through erosion. In other places coal beds fill the old gorges. Other physical breaks in the Coal Measures are indicated elsewhere along the same stream but at present they are more or less completely obscured by débris. These phenomena go to show that during the deposition of the coal-bearing strata numerous minor oscillations of the shore-line occurred, allowing the waters to recede slightly and then again advance inland.

Thickness of the Lower Coal Measures.-In connection with the leading geological features of central Iowa as brought out by an examination of some of the natural exposures, allusion should be made to the information pertaining to the Carboniferous rocks below the datum line of the general section. While the notes already taken are quite voluminous, they are not at present in shape suitable for presentation. All attempts to secure reliable accounts of the strata passed through in the borings and sinking of mine shafts have availed but little. since such information is almost invariably withheld by the parties in charge of the operations. For this reason the difficulties of working out the structural details of this part of the Carboniferous series were somewhat greater than they otherwise would have been; and the final results are thus considerably delayed.

As already stated the general dip of the strata along the present line of investigation is southwestward. The mean thickness of the Lower Coal Measures, as shown by careful measurement of the various members, must originally have been considerably more than seven hundred feet. This determination was arrived at in the following way: At the most easterly exposure of the section, the distance from the Saint Louis limestone to an easily recognizable 
bed near the top of the bluff was perhaps fifty feet in a direction normal to the dip. This particular layer was then traced to the point where it disappeared below the datum line and the measurement was repeated in the same manner as before. Of course it is not to be supposed that the present thickness of the Lower Coal Measures in central Iowa is nearly so great as the figures above given would suggest; for in reality the maximum vertical measurement of the beds is probably a little over one-half this estimate, or not far from four hundred feet, as is actully attested by borings. Erosion has largely removed the coal-bearing strata of the district, and therefore the original thickness of these rocks is not preserved in any one place.

Extent and Character of Individual Coal Beds.-There is an opinion prevalent among the miners of the district that there are only three workable coal horizons. These are usually designated as the "first," "second" and "third" seams. Should any subordinate seams be encountered in the sinking of a shaft, they are not taken into consideration. As a matter of fact the "three" veins are not continuous over areas of any great extent, and may have widely different stratigraphical values, even within very short distanees; the "first," "second" and "third" veins of one shaft being entirely distinct from the similarly called seams of another mine scarcely half a mile away. A noteworthy instance for citation in this connection is a boring made near the city of Des Moines. It was 200 feet in depth. Twelve distinct coal horizons were met with, giving a total thickness of coal of thirteen and one-half feet, yet none of the beds were thick enough for profitable working. Only one-third of a mile away was a 
mine removing coal from two seams, one of which was from four to five feet in thickness.

The stratigraphical importance of the coal seams is not so great as has been generally supposed, since the bituminous beds are, with very few exceptions, quite limited. Only a single case is known at present in which the geographic extent of a coal stratum is more than four or five miles, and for the greater part of this distance the coal is but a few inches in thickness. It follows that the coal seams of the region are not nearly so extensive as commonly regarded, and that they possess little value in general correlations.

The basal coal seams in the Lower Coal Measures of Iowa appear to be much more extensive than those toward the top, where they may be only a few inches in vertical measurement and perhaps a hundred yards in extenttoo small for representation in the general section. The coal may, therefore, be regarded as disposed in numerous basins of greater or less area, thickened centrally, but

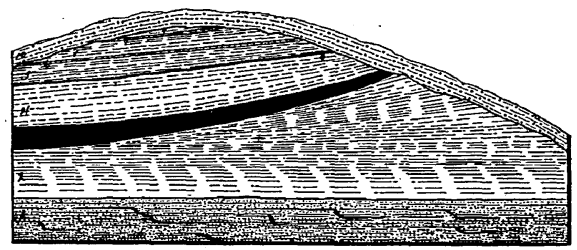

Figure It. Section in Railroad Cut at Terrace Hill, Des Moines.

gradually becoming attenuated toward the margins, as shown, in figure 11, at Terrace Hill, Des Moines. These are arranged in various horizons, interlocking with one another, but. separated by varying thicknesses of sand- 
stone and shale: Thus, at any one point a dozen or more seams may be passed through in sinking a shaft, only two or three perhaps being workable.

This arrangement is seen in the Des Moines river section of the Lower Coal Measures. (Plate vii.) It may be more clearly represented by figure 12 .

The disposition of the coal in numerous, limited, lenticular basins instead of a few layers extending over broad areas is of the utmost importance from a purely economical standpoint. In all mining operations and in all prospecting it is very essential that this fact be kept con-

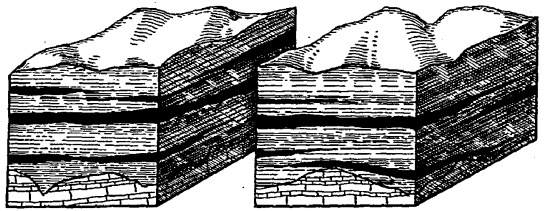

Figure 12 Stratigraphical Arrangement of the Iowa Coal Beds.

stantly in mind. With methods of boring more modern than those commonly in vogue throughout the western states, there is every reason to believe-that, in the Lower Coal Measures especially, the large majority of good coal veins twelve inches in thickness and over encountered in prospecting can be traced readily and easily to localities where they are thick enough for profitable working.

Interrupted Continuity of the Coal Beds.-In Iowa the restrictions upon the distribution of the individual seams are not numerous as compared with those of other regions. Yet there are disturbances of various kinds which break the continuity of the coal strata, locally interfering seiriously with mining operations. They are referable to the three general agencies of deposition, erosion and dislo- 
cation. The irregularities of deposition are due to (1) unevenness of the floor and (2) presence of varying currents at the time the beds were laid down. The effects of the inequalities of the bottom-the result of erosion or other causes-are to terminate the coal layers abruptly against a wall in an old channel or gorge; to cause a rapid thinning and disappearance of the bed, as in the neighborhood of an ancient elevation; to subdivide a coal basin, as when sharp ridges traverse the area. $\mathrm{Or}$, the converse of these results are effected in all those cases where depressions are present instead of elevations, causing local increase in the thickness of the coal. The existence of former currents results in an unequal accumulation of bituminous material.

The most serious interference with the continuity of coal beds arises from erosion. The erosive effects of later

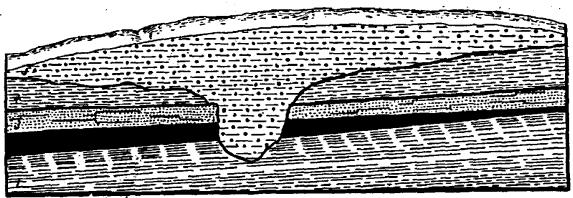

Figure 13. Preglacial Channel in Coal Bed. Des Moines.

geological or post-glacial times are easily inferred from the present topography of the region, and cause but little embarassment in mining operations. The work of preglacial degradation cannot be read from existing topographical features. Some of the most familiar phenomena of this kind met with in mines are old channels filled with sandstone or shales that cut off abruptly even the thickest coal veins. The accompanying figure 13 repre- 
sents a section in the Polk County Coal Mine in which an old gorge is buried by. glacial débris. Elsewhere these ancient waterways are filled up with arenaceous material of Carboniferous age.

So far as is known, regular faults are of little consequence in the Iowa Coal Measures; though small local slippings are often encountered.

MISSOURI FORMATION, OR UPPER COAL MEASURES.

Lithology of the Upper Coal Measures.

Clay-Shales.-As in the lower division of the Iowa Coal Measures the argillaceous materials of the upper part predominate over the other components. But instead of being as a rule dark colored, the clays of the upper division are light colored-calcareous rather than bituminous. The transitions from one lithologically distinct bed to another are much more gradual and the layers far more persistent than in the Lower Coal Measures. A pure clay stratum acquires more and more calcareous material until through various shaly stages it eventually becomes a wellmarked limestone. The clays carrying a high percentage of lime are popularly termed "marlites," and commonly yield large numbers of molluscan shells in a good state of preservation. Although there are many bituminous shales in the Upper Coal Measures of the State they are, for the most part, quite limited.

Limestones. - Next to the clays the limestones rank in importance in the making up of the Upper Coal Measures. Their presence forms the most prominent lithological difference between the upper and lower divisions. In thickness the beds vary from only a few inches to thirty feet, and even more. Many of the bands are somewhat earthy, but very compact, and break with a con- 
choidal fracture. The heavy layers may be thick-bedded or thin-bedded, the latter being, the more common. Fossils abound in nearly all the limerocks, especially those inclosed in calcareous shales.

The limestones, even in thin bands, are the most persistent of all the strata of the region-single beds having a wide geographical extent. Hence, in the recognition of horizons at different places the layers in question become very valuable as means of correct correlation.

The hard, calcareous beds, beginning in the uppermost part of the Lower Coal Measures with a few thin, impure bands of very limited extent, rapidly increase in number, thickness and importance upwards until, at the top of the series, they form great beds.

Arenaceous Naterials.-The sands of the Upper Coal Measures are largely disseminated through clays forming sandy shales or shaly sandstones. The massive sandstones are not common. They are chiefly confined to - limited layers of a few feet in thickness. Occasionally a bed of considerable vertical measurement is met with in the lower portions of the formation, but it is always very local.

Coal.-Over a large part of the Upper Measures coal seams of economic importance are not common. Deep boring, however, will probably disclose a large amount of workable coal. In fact this has already been accomplished with profit at Leavenworth, Kansas, and neighboring places.

\section{Stratigraphy of the Upper Coal Measures.}

From the remarks made in regard to the lithological characters of the upper division of the Coal Measures it may be inferred that inasmuch as the rocks were largely 
open-sea deposits, the stratigraphical continuity is more pronounced than in the lower section. This is, in fact, the case. Many of the beds are continuous over broad areas. The limestones in particular may be traced long distances.

Structure of the Iowa Coal Measures.

Heretofore the general impression has been that the Lower Coal Measures of the State were deposited prior to the laying down of the rocks of the Upper Division. Recent investigation seems to show that the two were formed contemporaneously; and that the former is to be regarded as a marginal or shore formation, while the latter is more of an open-sea deposit.

It has already been shown that just previous to the deposition of the Coal Measures in Iowa, Missouri and Kansas continental movements caused the shore-line of this region to recede several hundreds of miles to the southward. For a considerable period-during the Kaskaskia epoch-erosive agencies were actively at work on . the land surface which extended southward about as far as the present eity of Saint Louis. Shore deposits-sand. and clays-were laid down immediately beyond the placejust mentioned, while farther southward marine beds con-tinued to be formed conformably one above another.

When a new period of depression set in, coal marshes. were formed along the ever inland creeping shore-line. The more strictly marine deposits began to slowly extend. farther and farther northward, resting on the older calcareous beds as well as on the first formed marginal areas of sands, clays and accumulated vegetation. This process with many brief interruptions continued until the old shore-line had again gained its former place near the present Iowa-Minnesota boundary. As represented in. 
figure 8 , it will be seen that the coal or marginal beds were formed at the same time as certain calcareous layers farther outward; and that all formations along any given horizontal line (nearly horizontal, but having a slight inclination to the southwestward-the ordinary seaward tilt of the layers) were deposited contemporaneously. On a sinking coast the" marginal sediments would have, con-

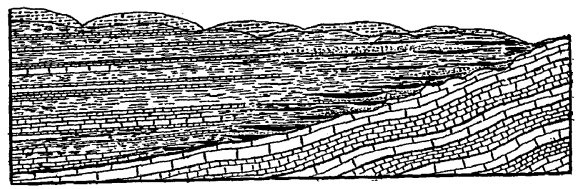

Figure 8. Ideal Cross-Section of the Iowa Carboniferous Rocks.

tinually, the later open-sea deposits laid down upon them, and the covering of the coal-bearing strata by the calcareous beds would constantly take place as long as the depression of the shore continued,

The "Lower" Coal Measures are not, then, a series of beds laid down previous to the deposition of the "Upper" Coal Measures. Each particular part of the former was deposited at the same time as portions of the latter farther seaward; the lines of contemporaneous deposition being nearly horizontal, yet having a common, though slight, seaward slope. As a whole, the "Lower" Coal Measures do actually lie beneath the "Upper" Coal Measures. But the line of separation is not a line drawn parallel, but obliquely, to the planes of sedimentation.

The essential difference between the two ideas is 
graphically shown in the following diagrams (figures 9 and 10):

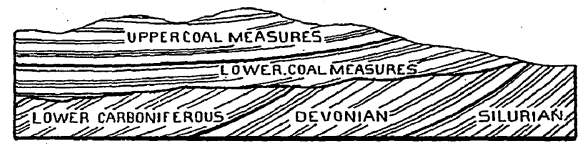

Figure 9. Popular Idea of the Relations of the Lower and Upper Coal Mfeasures.

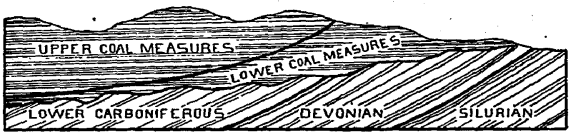

Figure to. Actual Relations of Lower and Upper Coal Mfeasures.

Beyond the point of the southernmost extension of the ancient shore-line, perhaps a little beyond the left hand terminus of the cut (figure 8), the limestones of the. Upper Carboniferous would lie upon the Lower with practically no evidence of any physical break. The faunas of the - Iatter would continue into the former with little or no change.

Oscillation of the Carboniferous Shore-Line.

It is the province of Geology to trace the history of events. In proportion to the exactness with which this historical sequence is followed is the sketch of value in explaining the minor details of local and economic importance. Regarding the Carboniferous of the Mississippi basin the most significant problem centers around the oscillation of the ancient shore-line. This change is diagramatically shoiri in the accompanying diagram, representing the movement of the land margin in the probable 
direction of greatest shifting. (Figure 14.) As already shown, the Devonian rocks are doubtless extended northward beyond the present limits of Iowa. Toward the close of the Devonian period the seas over this region gradually contracted. This recession continued more rapidly as the Lower Carboniferous period was ushered in, until the water-line reached nearly the present southern boundary of Iowa. The Saint Louis epoch represented a period during which there was a general depression of the land, allowing an overlap of the Saint Louis rocks of more than two hundred miles. Another cycle of great

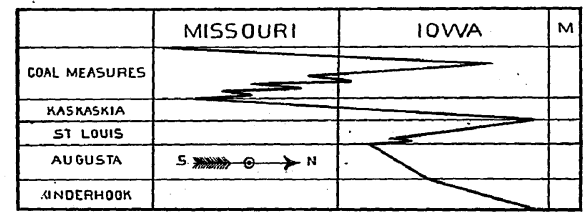

Figure 14. Changes of the Carboniferous Shore-Line.

continental change then set in, rapidly pushing the shoreline some five hundred miles southward, to the vicinity of the present city of Saint Louis. For the most part the Coal Measures represent a period of general, though not uninterrupted, subsidence. During the latter part of the period the waters receded rapidly far below the boundary of both Missouri and Iowa. A long time intervened before the sens again occupied the Iowa territory. This incursion was recorded in the Cretaceous deposits of the northwestern part of the State. Such is, in brief; a statement of the shore-line changes during the Carboniferous in the upper Mississippi valley. 
In considering now the nature of the physical break at the base of the Coal Measures in Iowa and Missouri, attention must be directed briefly to a few of the leading sections showing the line of contact between the two formations.

One of the most important exposures bearing upon the question under consideration has already been fully described in connection with the cross-section of the Lower Coal Measures of the central part of the State. It was shown that in Marion county, between Harvey and Redrock; a distance of ten miles, not less than seventyfive feet of shales were represented between two different horizons of the Coal Measures reposing against the Saint Louis limestone. The great part of the vertical distance just referred to appears to be due to irregularities in the limerock, which were carved out through erosion prior to the laying down of the Coal Measures.

Near Fairfield; in Jefferson county, the Coal Measure clays with their seams of carbonaceous matter rest directly upon the uneven surface of the Saint Louis marls which cap the limestone of the same age. The Lower Carboniferous rocks here contain fossils in abundance.

At Keokuk, Coal Measure deposits are found in numerous places near the top of the bluffs. The Saint Louis limestone as represented in this locality is partly a compact limerock, regularly bedded, partly a brecciated limestone. Everywhere in the vicinity the basal sandstone-a rather soft, friable rock of buff or brownish color - covers the uneven channeled surface of the Saint Louis limestone. Some of these sandstones with accompanying dark shales apparently rest also on the Keokuk limestone. Plate ix shows a typical section, in which the sandstone is seen resting immediately upon the limestone. The latter 


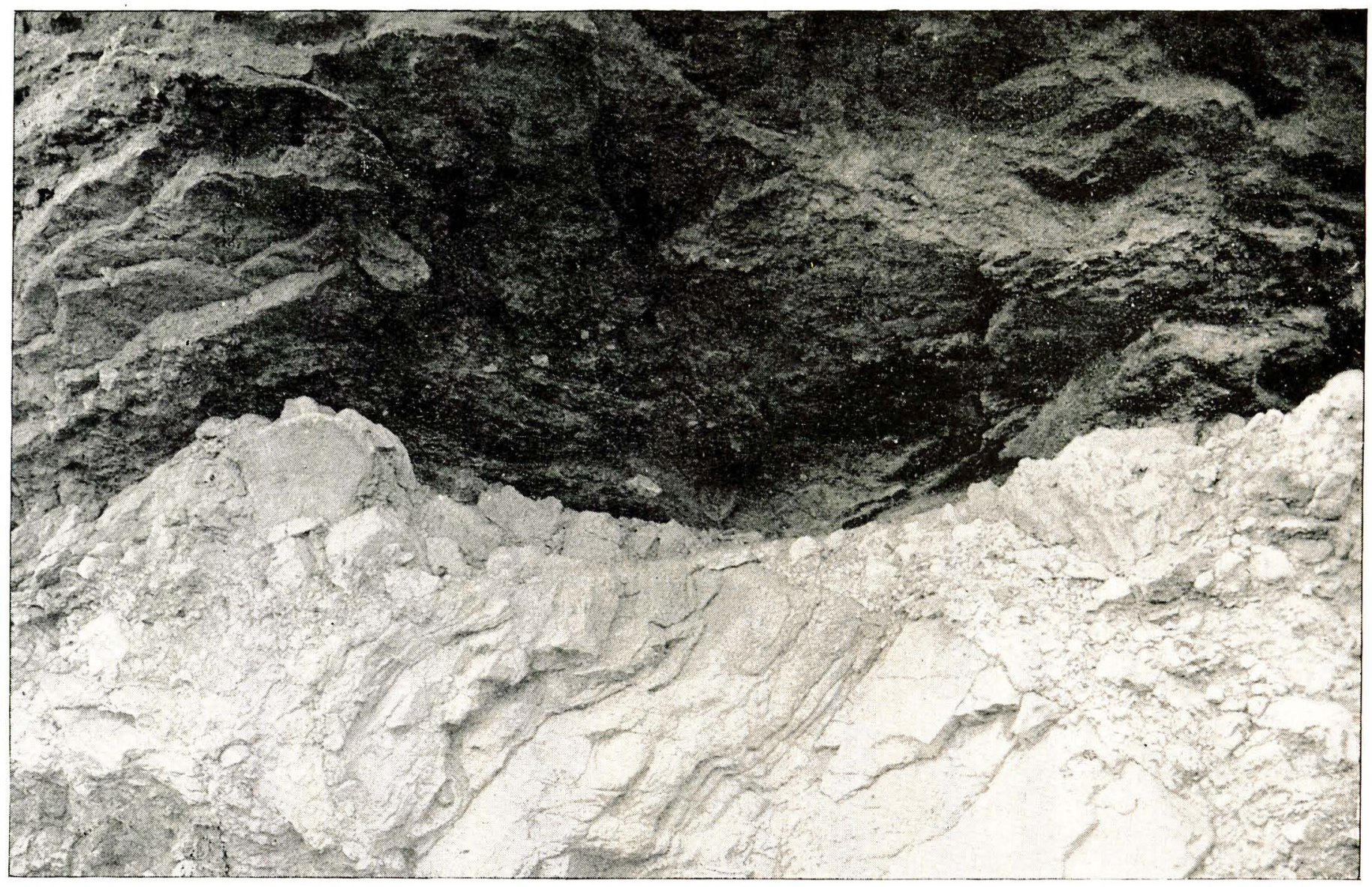

UNCONFORMITY BETWEEN THE COAL MEASURES AND ST. LOUIS LIMESTONE, KEOKUK. 

is brecciated; the former exhibits very marked cross. bedding.

At various places in Keokuk and Mahaska counties borings, as well as exposures, indicate that the irregularities in the surface of the Saint Louis limestone are even greater than those in Marion county already explained. The borings just referred to are quite numerous and special care has been taken with them for the reason that search was in progress for a "second" vein of coal-a seam much lower than the one being worked at present. In one place where the Saint Louis limestone was exposed at the surface, operations with a diamond drill were begun with hopes of reaching the "lower" coal bed. The reasons given for carrying on the work in this manner were that a mile away the coal at present worked was many feet lower down than the limestone outcrop, and therefore. the coal beds must lie beneath.

Relations similar to those above described have alsó been observed in connection with the Saint Louis limestone and Lower Coal Measures at Fort Dodge and elsewhere in Webster county. Identical cases might be. given again and again, if it were necessary in the present connection.

The unconformities in the Coal Measures have already been fully described in connection with the remarks on the stratigraphy of the region. The principal lines of local unconformity are shown in the section at Redrock, in Marion county, as well as other.places. These changes, with a number of minor oscillations of the shore-line northward and southward, took place before the great period of land elevation closed the Garboniferous period in Iowa. 


\section{Extent of the Coal Industry.}

Among the mineral products of Iowa that of coal takes first rank. The production for the fiscal year ending June 30,1890, according to the estimates based upon returns furnished by Mr. M. G. Thomas, State Mine Inspector, and from other sources, amounted to more than $5,340,000$ tons, valued at $\$ 7,750,000$. The mining of this great quantity of fuel gives employment to about 9,500 men. Besides, there are probably 8,000 additional men directly dependent for a livelihood upon the coal industry of the State.

The coal mine operators employing ten men and upwards are nearly 350 in number. Small owners having less than ten employees would probably increase the total number of separate organizations engaged in mining coal to something over 450 .

In regard to the total annual coal production in the United States the following table is deduced from Bulletins of the Eleventh Census of the United States:

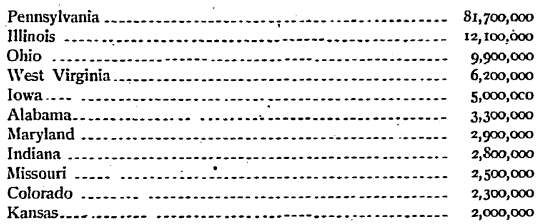

From the foregoing it will be noted that as a coal producer Iowa ranks first among the states west of the Mississippi river and fifth among the states of the Union.

Constructional Materials.

The building stones of the Coal Measures are among the most important in the State. In the lower division 
sandstones are more commonly represented. They are usually friable and thinly bedded, though certain localities yield massive freestones of very good quality. In Muscatine county a considerable quantity of Carboniferous sandstone has been quarried for local use. Quarries in rocks of this kind have also been opened in Webster, Boone, Jasper, Marion, Lee and Iowa counties. The best place, perhaps, in the State is at.Redrock, on the Des Moines river, about thirty miles below the capital of the State. The exposure is about one hundred feet high and supplies a fine-grained, brick-red and yellow rock. Recently quarries have been opened in this rock on a large scale. Steam channellers are used and then the stone is sawed into blocks and slabs of all sizes up to six feet or more. The Redrock sandstone has been used quite extensively throughout the State for architectural purposes. Besides a large number of other important buildings, the sevenstory Essex block at Des Moines is faced with this stone.

The Upper Coal Measures, in addition to a few local openings of sandstone, afford large quantities of good limerock. The most important quarries are at Winterset, Earlham, and near Council Bluffs, while smaller quarries are scattered through nearly all the counties within the area of the Upper Coal Measures.

Throughout all of the Coal Measures in Iowa occur unlimited quantities of clay of excellent quality for the manufacture of paving, pressed, fire and other kinds of brick. An excellent quality of potter's clay and material for tiling, terra-cotta, and in fact nearly all other kinds of clay products, are plentiful.

\section{CRETACEOUS.}

The Cretaceous rocks of Iowa are confined chiefly to the northwestern part of the State. They probably occupy 
a very considerable area, but at present the eastern limit is not known definitely on account of the thick deposit of drift over all this part of the State. Aside from the incidental references to the geology of this region made by the Long and other early expeditions, the first to call attention to the rocks of western Iowa was Nicollet, ${ }^{*}$ who identified as Cretaceous certain exposures above the mouth of the Big Sioux river. A.few years later, Owen, in his reconnaissance of the upper Missouri region, gave a full account of the Cretaceous rocks along the western margin of Iowa. A much more detailed examination of these rocks in the upper Missouri region was made by Meek and Hayden in 1853. A decade later Marcout and Capelliniß described the Cretaceous strata in the neighborhood of Sioux City. They also considered the rocks of this age to extend down along the Nissouri river to a point within a few miles of Council Bluffs. A year later White and St. John visited northwestern Iowa and regarded the rocks referred to the Cretaceous as separated into :

(3) Inoceramus beds.

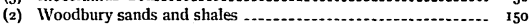

(1) Nishnabotna sandstone .............. 100

Still later McGeell placed the gypsum beds of Fort Dodge in the Cretaceous as its lowest member in Iowa. Beyond the probable eastern boundary of the Cretaceous in Iowa occur numerous small pockets and outliers which

${ }^{*}$ Report Intended to Illustrate a Map of the Hydrographic Basin of the Upper Mississippi River, Senate Doc., 26th Cong., 2d Ses., Vol. V, Part II, p. 237. Washington, $\mathrm{IS}_{4} \mathrm{r}$.

†Geol. Rep. Iowa, Wis. and Minn., p. 194. Philadelphia, 1852.

†Bul. Soc. Geol. de France, (2), t. XXIV, p. 56. Paris, 1866 .

sMem. Soc. Helvetique des Sci. Nat., t. XXII, pp. 1-24. IS67.

\|roth Census U. S., Vol. X, Special Report of Building Stones, p. 257. Washington, $1 \$ \$ 4$. 
have been referred to this age. The most important of these perhaps are some conglomerates found in scattered patches in different portions of central and northeastern Iowa. The largest of these occur in Delaware county and has been called by McGee the Rockville conglomerate. Most of the ferruginous conglomerates referred to are probably Carboniferous instead of Cretaceous. Similar masses are numerous in the Coal Measures themselves and often are unconformable with the underlying rocks. There has also been found in the drift in different parts of the State massive, soft, ferruginous sandstone boulders which sometimes contain fossils. One of the most recent of these discoveries was made a short time ago in the drift at Des Moines. The mass is charged with fossils of unmistakable Cretaceous types, the greater part of which are in a good state of preservation. When first discovered the fragment was perhaps two feet in diameter and contained upwards of a dozen species of fossils. A few of the best preserved specimens were taken at the time and the place revisited a few days later for the purpose of securing the whole piece, but unfortunately workmen had broken and removed it. The species obtained were: Otodus appendiculatus Ag., Lamna Texana Roemer, Fasciolaria culberstoni M. \& H., and Lunatia concinna M. \& H. Announcements have already been made of the occurrence in the drift of Iowa beyond the limits of known Mesozoic strata in situ of Cretaceous fossils and fossiliferous sandstone. White has reported an Ammonite from Waterloo, Iowa, a fragment of Baculite from Iowa City, ${ }^{*}$ and six specifically determinable fossil forms from Hardin county ; $f$ and he has

${ }^{*}$ Geol. lowa, Vol. I, p. g8; also Proc. Am. Ass. Ad. Aci., Vol. XXI, pp. 187192.

†Am. Geol., Vol. I, p. 223. 1888. 
shown that the facies of the fossils in question has a close affinity with that of the fauna of the Fox Hills group, or the uppermost portion of the marine Cretaceous of the continental interior. The recently discovered Des Moines specimens afford additional evidence in support of this supposition. The good preservation of the molluscan remains, though so fragile, together with the fact of the comparative softness of the ferruginous sandstone, suggests, as in the other instances mentioned, that the fragments of Cretaceous strata are not far removed from the locality of original deposition. The satisfactory determination of the eastern extension of the Cretaceous in Iowa is attended with much difficulty, chiefly on account of the great depth of the drift, covering the northwestern portion of the State. Doubtless extensive outliers will be discovered considerably to the eastward of the present ascribed limits.

During the past year a number of deep wells have been put down in various parts of northwestern Iowa. The depth of these borings vary from one to two thousand feet. All of those examined show that the drill has passed through from two to three hundred feet of strata which is undoubtedly Cretaceous in age. The principal wells referred to are those put down at Sioux City, Le Mars. Hull and Cherokee. At Peterson and Emmetsburgh similar records have been kept. These investigations would clearly indicate that in Woodbury, Plymouth, Sioux, Cherokee, Clay and Palo Alto counties the Cretaceous deposits are well represented immediately below the thick mantle of drift. These localities of Cretaceous deposits, so much farther eastward than has been generally supposed heretofore, and the considerable thickness which these beds present along the line of the eastern- 
most places, go to show that the rocks of this age doubtless extend at least fifty miles still farther to the eastward.

The best natural exposures of the Cretaceous now known in Iowa are along the Big Sioux river in Woodbury and Plymouth counties. The latestinformation relating to these rocks may be gleaned from the notes of Professor Calvin, who has recently visited this region. His observations are summarized in the following paragraphs:

"A generalized section of the beds along the bluffs facing the Big Sioux river, omitting some details and averaging local peculiarities of certain beds, would be :

9. Calcareous beds consisting of chalk and soft, thin-bedded limestone, containing shells of Inoceramus problematicus, Ostrea congesta, and teeth of Otodus, Ptychodus and other Selachians. 30

8. Shales, more or less unctuous, somewhat variable in color and texture, containing remains of Saurians and teleost fishes, the upper beds sometimes bearing impressions of Inoceramus

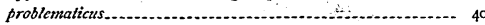

7. Argillo-calcareous or arenaceo-calcareous beds, with much selenite (varying with locality).

6. Blue, yellow and red mottled clays (terra-cotta clays), with selenite crystals and some streaks of sand........................ 30

5. Band of impure lignite-.......................... 4 to 6 inches

4. Shales, with usually two, but sometimes more, well marked thin bands of ferruginous concretionary sandstone ("buttons" of the clay workers).

3. Massive sandstone, mostly soft, but in places containing large concretionary masses several feet in diameter; in appearance and hardness resembling quartzite.............................. so

2. Gray and mottled shales, with thin ferruginous bands and arenaceous layers................................................... 12

I. Irregular beds of sandstone, varying in color and texture and interstratified with thin beds of shale........................... 18

"Beds that are quite constant and easily recognizable in the region about the mouth of the Big Sioux river are numbers $3,4,5,6$ and 9 . These, either singly or collectively, become the guides whereby the beds of the 
several exposures may be correlated. The deposits were traced up the Big Sioux valley for a distance of forty miles; they were followed up the Missouri river as far as Yankton.

"Below the mouth of Iowa creek, about three miles east of Ponca, Nebraska, the Missouri river washes the foot of a high bluff in which Cretaceous strata, identical in all essential respects with those seen in Iowa above the mouth of the Big Sioux, are exposed to a height of more than one hundred feet. The several beds of the preceding section, from 2 to 8 inclusive, are easily recognized, and at the summit of the section, cropping out. from beneath the thick mantle of loess, are indications of the chalky beds of number 9 . Farther up the river, almost directly north of Ponca, there is another splendid natural section which is more than a mile in length and at least $\mathbf{1 6 0}$ feet in height. At the base of the section are the beds seen below the mouth of the Iowa creek, while above all the sandstones and shales lie from twenty to thirty feet of rather hard chalk and Inoceramus-bearing limestone. There can be no doubt that the beds near Ponca, Nebraska, are the exact equivalents of beds in Iowa. Indeed one may look away from the exposure at the bend east of Ponca, across the plain which is here the combined valley of the Missouri and Big Sioux, for a distance of ten or twelve miles to the corresponding exposures in Iowa. In the two bluffs that look toward each other from opposite sides of the plain, the same succession of strata may be traced that, but for the erosion of chalky, marly or calcareous beds which are the exact equivalents of the Inoceramus beds of Iowa, are referred to the Niobrara group. The dark colored shale, identical with number 8 , of the preceding section is called the Fort 
Benton group, while all the complex mass of alternating sandstones and shales in the basal portion of the exposure is recognized as belonging to the Dakota group.

"Between Ponca and Saint James, about thirty miles in a direct line farther up the Missouri, the chalky beds of the Niobrara group crop out on all the hill tops. The village of Saint James is situated in the valley of Bow creek, below the level of the chalk. In the eastern edge of the village is an exposure of Fort Benton shales presenting the same characteristics as seen at a recent landslide on the Williams and Smith farm, a few miles north of Sioux City, Iowa, and at the exposures near Ponca; Nebraska. On the tops of the hills near the mouth of Bow creek the dark Fort Benton shales are succeeded by white or cream-colored chalk of the Niobrara division.

"Saint Helena, about eight or nine miles above Saint James, is situated on a high bluff one hundred and thirty to one hundred and forty feet above the level of the Missouri river. The bluff rises as a vertical wall almost from the edge of the water. Between the river and the vertical escarpment the base of the bluff is concealed by a talus composed chiefly of great blocks of chalk, but above the talus and rising to a height of fifty feet above the water, is an excellent exposure of the dark shales of the Fort Benton group, differing in no essential respect from the corresponding shales exposed at the land-slide above the creamery of Williams and Smith, or the shales occupying the same stratigraphical position near Ponca and Saint James. Above the Fort Benton shales lie ninety feet of soft chalk belonging to the Niobrara. The Niobrara beds at Saint Helena exhibit some points of difference from 
those seen on the Big Sioux, or on the Missouri across the valley in Nebraska. The valves of Inoceramus are no longer present in large numbers, but some of the layers are crowded with Ostrea congesta. The beds are uniformly chalky throughout, no part of the deposit being as much indurated as the Inoceramus-bearing beds near Ponea or Sioux City. The exposure at Saint Helena is probably one of the most striking and interesting along the river, and Hayden refers to it time and again in his work.

"At Yankton, South Dakota, a short distance above Saint Helena and on the opposite side of the Missouri, the Niobrara beds are developed in great force. A large factory has been established about three miles west of Yankton to utilize the chalk in the manufacture of Portland cement. The part of the formation at present worked into cement lies above that exposed in the bluffs at Saint Helena. It presents a breast about forty feet high. Below the base of the present working the chalk is known to descend to a depth of about ninety feet. The Fort Benton shales have disappeared beneath the level of the river; at all events, they lie below the level of any observed exposures. On the hill tops above the cement factory the chalk of the Niobrara is overlain by the shales of the Fort Pierre group. Hayden speaks of this group as making its appearance on the summit of the hills near the mouth of the Niobrara, but he might have found it thirty miles farther east, developed to a thickness of fifteen or twenty feet.

"The shales of the Fort Pierre group above the chalk, and of the Fort Benton group below, are highly charged with crystals of selenite, and this mineral is by no means uncommon in the shaly portions of the Dakota group near Ponca and Sioux City. 
"With reference to the taxonomy of the Iowa section, beds 1 to 7 inclusive are the stratagraphical equivalents of beds near Ponca, Nebraska, which Hayden refers to the Dakota group. Number 8 includes beds that at Ponea and Saint Helena have been referred to the Fort Benton group by the same author, and the Inoceramus beds, number 9 , are the exact equivalents of the lower twenty or thirty feet of the Niobrara group. A part of the Inoceramus beds near Sioux City is soft and chalky; but a part, as has been said, is harder, though by no means as hard as ordinary limestone. At Saint Helena, Nebraska, and, so far as known, at Yankton, South Dakota, the beds are chalky throughout, the difference being doubtless due to the fact that the Sioux City area was nearer the shore-line of the Cretaceous sea in which the beds were deposited. At Ponca, Inoceramus is about as common as at Sioux City, but the strata in which the shells are imbedded are lithogically intermediate between the condition of the Inoceramus-bearing layers at Sioux City and the condition observed in the basal parts of the Niobrara group at Saint-Helena. Furthermore, the beds referred by Hayden to the Dakota and Fort Benton groups are as well developed at Sioux City as at Ponca. At Sioux City, however, we have only the attenuated edge of the Niobrara, but that fact in no way disqualifies so much as is developed from being the stratigraphical equivalent of the lower portion of the group, as seen in greater force farther up the river.

"The three divisions of the Cretaceous recognized at and near Sioux City in reality represent continuous sedi- mentation over a gradually subsiding sea bottom. The sandstones and shales of the Dakota group, with respect to the lower portions at least, were accumulated in a 
rather shallow, land-locked sea. Currents swept the sand back and forth, sometimes building up and again tearing down previously constructed beds, and so produced the fine examples of cross-bedding, or current structure, so well illustrated near Springdale, a few miles northeast of Sioux City. The few molluscan species found in the lower part of the Dakota group indicate the presence of brackish water. The numerous vegetable remains which characterize the group imply that the large volumes of drainage water which maintained the conditions favorable to the existence of brackish-water mollusks carried not only sand but swept in leaves and trunks of the willow, poplar, magnolia, and other forest trees, from the adjacent lands.

"As the waters became gradually and progressively deeper, owing to subsidence of the sea-bottom, the conditions favoring the accumulations of sandstones and the existence of brackish-water mollusks disappeared. The shore-line was shifted farther to the east. The sediments of the region about Sioux City became finer and settled down in irregular layers beyond the reach of disturbing currents. The downward movement of the sea-bottom seems not to have been altogether constant during the epoch of the Dakota group. There were occasional oscillations that from time to time permitted the formation of thin beds of sandstone, but before the close of the epoch the amount of sand that reached as far as Sioux City was insignificant, and fine clay-shales predominated. The shales of the Dakota group gradually merge into those of the Fort Benton. During the second epoch the subsidence had carried the shore-line so far to the east that all coarse sands were deposited before reaching the area in question. Before the Fort Benton epoch began the 
brackish-water estuary had long been transformed into a portion of a clear open sea. At all events, during the epoch true marine mollusks such as Inoceramus and Ostrea had supplanted Cyrena and Margaritana, while marine Saurians and teleost fishes multiplied and became the denominating types of the oceanic realm.

"The soft limestone and softer chalk of the Niobrara group are indicative of still deeper water and remoter shores. During this epoch no gross sediments from the land reached as far as Sioux City. Not since the earlier part of the Dakota group had it been possible for leaves and twigs of forest trees to be carried into the region. It was during this Niobrara epoch that the subsidence reached its maximum and the maximum extension eastward of the Cretaceous sea was attained. Toward the close of this epoch the upward movement of the land began, the sea withdrew, and the shales of the Fort Pierre. group were deposited above the chalk from Yankton westward."

There are two formations in Iowa which are probably Cretaceous in age, but whose exact stratigraphical positions are at present somewhat doubtful. These formations are the Fort Dodge gypsum deposits and the Nishnabotna sandstone.

It has been shown in some of the preceding paragraphs that the Cretaceous deposits in Iowa were laid down on a gradually sinking sea bottom; this being the case, the earliest deposits of this age would have been laid down along the western margin of the State. The later beds of this epoch represented in Iowa gradually form an overlap of considerable extent, probably reaching nearly to the Mississippi river. The lowermost Cretaceous beds represented in Iowa in the vicinity of the Mis- 
souri river would be the Woodbury formation (Dakota, in part, of Hayden). The Niobrara group would thus probably be represented eastward by shore sediments which would be the beds lying upon the Paleozoic strata of central and northern Iowa. The eastern marginal deposits have heretofore been referred to the lower instead of the upper Cretaceous rocks, insofar as they have been considered in Iowa. But the case is identical with the one already explained in connection with the remarks on the Coal Measures; and the marginal deposits.should probably retain the name of $\mathrm{T}$ oodbury shales or sandstones.

NISHNABOTNA SANDSTONE.

This sandstone, usually referred to the Cretaceous, has never been directly traced to outcrops of the Woodbury shales. The geographical distance between the nearest exposures of the two formations, as at present known, is very considerable. If the Nishnabotna is Cretaceous; it may be the equivalent either of the Woodbury shales or of the Niobrara chalk; which one it is cannot now be stated. In regard to the gypsum beds, their formation indicates a saline lake deposit, such as might be left by a retreating ocean. This fact, taken in connection with the probable great eastern extension of the Niobrara, suggests that the Fort Dodge beds were formed during the retreat of the Niobrara waters through Iowa. At the present time it seems best not to attempt a specific correlation of either the gypsum deposits or the Nishnabotna sandstone, but merely regard them as Cretaceous in age. The sandstone and loose sands that have been called Nishnabotna are to be regarded as shore deposits along with numerous other beds of similar character which occasionally are found as outliers through central and northern Iowa. 
The Nishnabotna has a known maximum thickness of one hundred feet. It is seen exposed in the southeastern part of Guthrie county, southern Montgomery county and elsewhere in the western part of central Iowa. Quarries have been opened in these rocks at Lewis, in Cass county. In its lithological characters the formation varies from a fine or coarse-grained sandstone, white to dark brown in color, and usually quite friable, to a compact, ferruginous pudding-stone. Occasionally thin clay seams are intercalated. Beds of gravel are not infrequent.

\section{FORT DOJGE BEDS.}

This name is applied to the gypsum deposits and certain associated beds which are well exposed in the neighborhood of Fort Dodge. The gypsum attains a vertical measurement of from two to thirty feet; its average thickness being perhaps about fifteen or sixteen feet. It : occupies an area, in the central part of Webster county, of about twenty-five square miles. It is traversed north and south its entire length by the Des Moines river, and is cut through by many of this stream's smaller tributaries. Probably more than one-half of the entire deposit has been removed through the erosion of the water-course. The most extensive exposures now open are about six miles below Fort Dodge. At Duncombe's quarry, on the south side of the river, the following section is shown :

3. Heavily bedded gypsum ....................................... 6

2. Heavily bedded gypsum, somewhat impure ................... 8

I. Drab and variegated clays (Coal Measures), exposed............ 30

The gypsum exposed throughout the region is the massive variety. It is made up of thin layers alternately white and drab, the former being very pure. North 
of Fort Dodge, at Kohl's brewery, an old quarry face gives the following section:

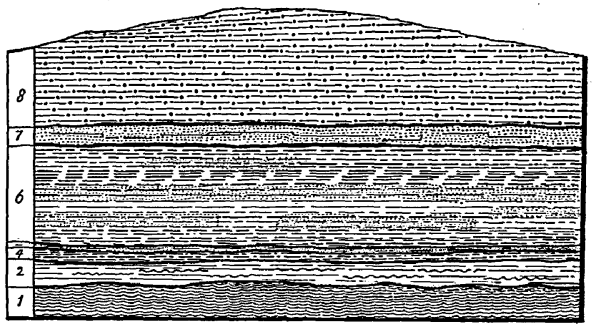

Figure 15. Quarry-face at Kohl's Brewery. Fort Dodge.

FEz

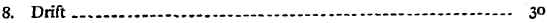

7. Soft, friable, buff sandstone, heavily bedded.................. 5

6. Argillaceous and sandy shales, alternately _...

5. Massive, buff sandstone, quite friable .............................

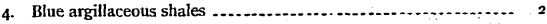

2. Brown and reddish clay, with sandy layers, and layers of white and gray bands of gypsum from four to six inches thick and

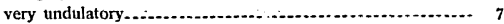

I. Massive gypsum, exposed ............ 5

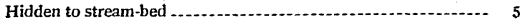

Number 1 of this section is probably several times as thick as the surface exposure indicates, and probably rests directly on the Saint Louis limestone. It is a significant fact that in the sandy shales immediately overlying the massive gypsum beds thin bands of gypsum are intercalated. It is quite likely that leaves of plants will be found in these beds after a careful search.

Along the northern portion of its area the gypsum lies directly upon the Lower Carboniferous limestone just mentioned, but at its southern limits a considerable 
thickness of Coal Measure clays and shales intervene between the two formations.

Barometric measurements of about twenty of the leading gypsum exposures show that the gypsum was deposited on a slightly uneven surface. The difference in elevation between the north and south exposures is thirty feet, the northern part being the higher.

In the light of the recent geological observations in northwestern Iowa, which indicate that undoubted exposures of the Cretaceous occur much farther eastward than has heretofore been commonly regarded, it would appear that the gypsum beds and the accompanying overlying shales may be considered as Cretaceous in age, and that they were probably deposited at the same time as were the Niobrara chalks along the Missouri river near Sioux City.

Uses.-To some extent the massive gypsum of Fort Dodge has been quarried for building purposes. A number of buildings and foundations have been constructed of this material. It has also been used quite extensively for heavy masonry. Its most important use, however, is its manufacture into stuceo and land-plaster. During the past year more than fifty thousand tons of these materials were manufactured in the vicinity of Fort Dodge.

\section{WOODBURY SHALES.}

As already intimated the typical outcrops of this formation are to be seen in Woodbury county along the Big Sioux river. The lithological characters have already been sufficiently described. The formation corresponds essentially with the Dakota and Fort Benton. groups of Hayden. They represent shore deposits and it seems desirable to retain the name in preference to the two 
proposed by Hayden. " Woodbury", as defined by White, expresses more accurately than any other. name yet proposed the lithological features of the rocks as represented in Iowa.

The Woodbury shales are made up largely in certain places of the sandstone which sometimes forms hard concretionary masses not unlike quartzite. In some localities these masses are so near together that they may be quarried to advantage for building-stones. The most important of these openings is in the vicinity of Sioux City and is known as Reese's Granite quarry. The rock has apparently all the qualities of the regular crystalline massive rocks. The greater portion of the Woodbury shales are argillaceous and afford inexhaustible quantities of good clay for the manufacture of pottery, fire and paving brick.

\section{NIOBRARA CHALK.}

These beds in their chalky facies have been observed in Iowa in the vicinity of the Big Sioux river. They are probably represented farther eastward by more strictly shore deposits. Their lithological characters have already been given at length and their economic value pointed out.

\section{SURFACE DEPOSITS.}

Over all Iowa, covering the indurated rocks to a depth from a few inches to two or three hundred feet, is a mantle of loose incoherent material. This material is chiefly of three kinds; known as the drift, loess and alluvium. The latter may be regarded as the deposits of the modern rivers ; the former two as glacial débris.

AlLuviuM.

Little need be said here in regard to the alluvial deposits. They are the fine sediments laid down in the 
river valleys making up what are commonly known as the flood plains. Many of the river terraces are also alluvial. These materials will be treated at length in another place in connection with an account of the soils of the State.

\section{DRIFT.}

To the heterogeneous mixture of clay, sand, gravel and boulders which are seen everywhere throughout the State has been applied the name of drift. Everywhere the proportion of the drift constituents vary. They change rapidly from place to place, passing from one phase into another. The clay forms by far the largest portion of the mixture and is usually mingled with more or less fine sand. In color it has a characteristic brown or buff tint. When excavated the surface exposed quickly breaks up into small cubic or angular fragments. It is commonly known as joint-clay. The sand and gravel often form considerable beds, yet they are usually quite limited in extent. The boulders are chiefly fragments of crystalline masses of northern origin. They represent a great variety of eruptive and metamorphic rocks.

The drift is largely of glacical origin and, as shown . elsewhere, is made up in Iowa of two sheets. The lowest or earliest drift forms a part of the great drift mantle extending over northern United States. In the Mississippi valley it has its southern boundary approximately along the line of the Ohio and Missouri rivers. The upper till belongs to a later glacial epoch, and is included within the area, bounded by what is known as the moraine of the Des Moines lobe of the second great ice invasion. This forms a narrow triangle in Iowa with its apex reaching to the city of Des Moines.

According to McGee,* who has given particular atten-

*U. S. Geol. Sur., 11th Ann. Rep., p. 540. Washington, 1893 . 
tion to the surface formations of northeastern Iowa, "The uppermostiglacial deposit, which forms the surface over half the territory, is a generally continuous ground moraine or sheet of boulder clay, yellow, buff or brown in color and interspersed with subangular or rounded and sometimes striated pebbles and boulders, much the greater proportion of which came from far beyond the limits of the State. Its surface not only exhibits characteristic ice moulding, but is, particularly in the northwestern portion of the territory, dotted with immense granitic boulders. Its continuity is commonly interrupted, not only by postglacial erosion along a few streams and by a few protruding crags of indurated rock, but through thinning out to a bare veneer upon the older deposits. The structure, like that of ice-formed deposits elsewhere, is fairly homogeneous in the large way, though heterogenous in detail; and its thickness ranges from a veneer to probably one hundred feet, averaging perhaps twenty feet. It is noteworthy that the element of pebbles and boulders is much less than is commonly found in homologous deposits in northeastern United States, but that at the same time the boulders reach exceptionally large dimensions. Thus the soil is so nearly free from pebbles as to yield readily to the plow, and the fields are easily cleared of other boulders than the granitic masses which are so large as to be quarried, constituting a valuable source of building material.

" Toward its periphery in general, but particularly in the south, the upper drift sheet undergoes modification; the superficial boulders disappear, the materials become finer, the surface assumes a characteristic longitudinal ridging, the superficial portion passes into a loam, and the glacial deposit either grades upward into a superimposed mantle of loess or is overlain, with a certain unconformity, by that 
deposit commonly with an intervening bed of immediate character; and only rarely do local terminal moraines mark the margin of the deposit.

"The lower till, or older glacial deposit, is the homologue of the upper and newer, and its distribution is much the same, though its continuity is more frequently broken. Its materials are much the same, though the prevailing color is blue and the alternative color brown; the pebbles are more numerous and smaller; there is a dearth of huge granite boulders, and there is throughout the mass a larger proportion of green-stones than in the newer deposits; and its thickness runs from a veneer to more than two hundred feet, so that despite its more frequent and larger breaks of continuity its average thickness is perhaps twice that of the upper till.

"There is a peripheral modification of this drift sheet more decided than that of the lower. Toward its margin it differentiates into a lower member much like the mass of the deposit in the interior, and an upper member of clean, plastic elay, sometimes laminated and bearing other indications of water-laying. There is also a more general division of the deposit into a main body of boulder clay and an inferior bed of gravel, pebbles, cobbles; and boulders. No traces of a terminal moraine are found about the margin of this drift sheet.

"The other glacial deposit is seldom exposed save in artificial excavations; but these indicate that over half the area the deposit passes upw ard into a soil or bed of humus charged with remains of arboreal vegetation. The identifiable remains of the ancient trees are chiefly sticks, logs, and stems of coniferous woods; but fragments of hard woods and also impressions of leaves and traces of other vegetation are frequently found. The 
abundance of these vestiges of an ancient soil and its products are so abundant, so widely distributed and so related to the indications of subsequent glaciation as to prove that the older drift sheet was covered with soil and largely clothed with forests before the later ice invasion commenced; and the indications are that the old soil was much thicker and the ancient flora much more luxuriant than those of to-day.

"The older glacial deposit commonly rests either on the indurated rocks or on a mantle of residuary material derived therefrom; yet few and scant traces of antecedent vegetation have been found at its base. The general destruction of the ante-Pleistocene surface and the greater thickness of the inferior glacial deposit suggest that the earlier glaciation was the more energetic and the longer continued.

"Toward the margin of the glaciated area, both drift sheets occasionally pass into local deposits exhibiting glacial structure, though made up largely of local materials which are found only in valleys; and these deposits and the associated land forms are supposed to indicate that the attenuated margin of the ice first filled and afterward rode across transverse valleys."

LOESS.

This deposit is well displayed along the Missouri and Mississippi rivers and at numerous places throughout the interior of Iowa. The following paragraphs, also gleaned from McGee in his study of the formation of the Mississippi valley, well describe the leading features of the formation as represented in Iowa :

"The macroscopical characters of the deposit are moderately constant; (1) it is commonly fine, homogeneous, 
free from pebbles or other adventitious matter, and either massive or so obscurely stratified that the bedding planes are inconspicuous; (2) it commonly contains unoxidized carbonate of lime in such quantity as to effervesce freely with acid; (3) it frequently contains nodules and minute ramifying tubules of carbonate of lime; (4) in many regions it contains abundant shells of land and fresh-water mollusca; (5) it is commonly so friable that it may be removed with a spade or impressed with the fingers, yet it resists weathering and erosion in a remarkable manner, standing for years in vertical faces and developing steeper erosion slopes than any other formation except the more obdurated, clastic or crystalline rocks.

"Its microscopical characters are much less constant: It is commonly a mass of indiscriminately commingled grains of quartz, and a great variety of other rocks, of ever varying size and degree of rounding by attrition; but in some localities and in certain strata the materials are coarser and graduate into sand, while in other localities and in certain other strata they are finer and more uniform and pass into silt or mud.

"In short, while loess is one of the most distinctive deposits of the entire clastic series, and while it is easily and, in most cases, certainly identified by student and laymen alike, there is probably no single characteristic of structure or composition that can be considered constant.

"Despite the variability in its composition and structure and despite the peculiarity in its distribution, loess possesses one characteristic which is nearly, if not quite, universal and which measures its value to man. Its chemical composition may imitate that of alluvium, drift, or rock; its materials may be identical with those of granite, limestone, sandstone, shale, or several or all 
of these combined; but the materials are so comminuted and so assorted as to render the mass friable and porous. So it absorbs the water of the freshet like a sponge and holds it for midsummer drouth, and during the drouth the waters are brought up by capillarity to nourish the plants at the surface: it yields to the plow like cheese to the knife and is neither bed rock or boulder to intercept the roots of annual plant or sturdy tree, and the rootlets penetrate to astounding depths through the porous mass and gather sustenance from the finelypulverized rocks, débris, and the imprisoned waters; the water and air circulate freely, and the acid of plant decomposition follow them and render soil and subsoil alike fit for plant food. So the loess of the Rhine is famed for its vineyards; the loess of Mangolia supports a pastoral population in a region which without it would be desert; the loess of the plains adjacent to the Missouri river brings agricultural and pomological prizes in plenty to a region in which the pioneer feared to settle by reason of the limited rainfall; and in northeastern Iowa the formation may be mapped by its fruitful vineyards and orchards, and by the capacious barns and commodious farm houses built upon it. To 'the farmer, who feedeth all,' the loess is one of the most beneficent among the gifts of the earth." 